\title{
The Economic Contribution of West Virginia's Forest Products Industry
}

Charles Clinton Gabbert

West Virginia University, cgabber1@mix.wvu.edu

Follow this and additional works at: https://researchrepository.wvu.edu/etd

Part of the Other Forestry and Forest Sciences Commons

\section{Recommended Citation}

Gabbert, Charles Clinton, "The Economic Contribution of West Virginia's Forest Products Industry" (2019). Graduate Theses, Dissertations, and Problem Reports. 3837.

https://researchrepository.wvu.edu/etd/3837

This Thesis is protected by copyright and/or related rights. It has been brought to you by the The Research Repository @ WVU with permission from the rights-holder(s). You are free to use this Thesis in any way that is permitted by the copyright and related rights legislation that applies to your use. For other uses you must obtain permission from the rights-holder(s) directly, unless additional rights are indicated by a Creative Commons license in the record and/ or on the work itself. This Thesis has been accepted for inclusion in WVU Graduate Theses, Dissertations, and Problem Reports collection by an authorized administrator of The Research Repository @ WVU. For more information, please contact researchrepository@mail.wvu.edu. 


\title{
THE ECONOMIC CONTRIBUTION OF WEST VIRGINIA'S FOREST PRODUCTS INDUSTRY
}

\author{
C. Clinton Gabbert
}

\begin{abstract}
THESIS
submitted to the Davis College of Agriculture, Natural Resources, and Design at West Virginia University in partial fulfillment of requirements for the Degree of Master of Science in Forestry

\author{
Kathryn Arano Gazal, Ph.D., Chair \\ Joseph McNeel, Ph.D. \\ John Deskins, Ph.D.
}

Morgantown, West Virginia

2019

Keywords: economic contribution, forest products industry, input-output analysis, economic impact, West Virginia forest products

Copyright 2019 C. Clinton Gabbert 


\section{ABSTRACT \\ The Economic Contribution of West Virginia's Forest Products Industry \\ C. Clinton Gabbert}

The hardwood forests that cover West Virginia have historically been an important resource to the state. The turbulent economic conditions resulting from the U.S. housing market collapse of the mid-2000s and subsequent economic recession have cause immense disruptions in the country's forest products industry (FPI). An assessment of the economic contribution of the state's FPI and the 7 major forest product sectors which comprise it was completed using the input-output economic modeling software IMPLAN with 2017 data. The historical contribution of the state industry was then assessed and compared for the years 2006, 2010, 2015, and 2017 to examine the changes in the industry's contributions among these years. Finally, an assessment of the FPI's economic contribution in five separate regions of the state for the years 2006 and 2017 was performed. As of 2017, the West Virginia FPI directly contributed $\$ 2.2$ billion in output, 10,198 jobs, $\$ 750.5$ million in gross state product (or value added), and $\$ 404.5$ million in employee compensation to the state economy. In terms of total contributions to the broader economy, the industry supported $\$ 3.4$ billion in output, 19,219 jobs, $\$ 1.4$ billion in gross state product, and $\$ 764.4$ million in employee compensation. In 2017, the primary solid wood products sector was found to be the largest individual FPI sector in terms of direct contributions of output, jobs, and employee compensation while the logging sector was the largest in terms of value added. In 2006, the West Virginia FPI directly contributed $\$ 2.8$ billion in output and over 15,000 jobs, while supporting $\$ 3.7$ billion in total output and nearly 21,000 jobs in the broader state economy. Immense decreases in industry contribution were found in both the direct and total contributions of the industry from 2006 to 2010. The largest percentage decreases between these years were experienced in the secondary solid wood products and wood furniture sectors. Between 2010 and 2015, the industry direct contributions rose by all measures except employee compensation, which continued to fall by 1.5 percent of its 2010 level of $\$ 395$ million. Increases in indirect and induced contributions of the industry, however, resulted in increasing total contributions of all measures. Between 2015 and 2017, all measures of direct contributions of the industry increased, but failed to rise to their previous 2006 levels of any measure analyzed. This was also found to be the case of the FPIs in the five regions of the state that were analyzed. The Highlands region, comprised of 11 counties in the eastern portion of the state was, by far, the largest contributor to the state's FPI in both 2006 and 2017. By 2017, the region provided more than half of the statewide industry's direct contributions of output in the logging and primary and secondary solid wood products sectors. The North Central region of the state, meanwhile, experienced most of the largest losses in direct and total contribution of the state from 2006 to 2017. As of 2017, the West Virginia FPI remains a key industry for the state as total industry contributions accounted for 2.2 percent of all jobs and 1.8 percent of gross state product. While these shares are still below 2006 values, they were seen to have increased from 2010 to 2015 and 2015 to 2017. However, the inability of the FPI throughout the state to return to 2006 levels of direct contributions suggest long-term industry trends such as the continued offshoring of valueadded forest products sectors and increased industry automation are still putting negative pressure on direct industry growth. Additionally, new challenges the industry faces may be diminishing industry contributions such as the uncertainty about the future availability of the 
foreign markets and competition for labor from new industries. In order to meet these challenges, it is recommended that state and federal policymakers, developmental authorities, and other industry interests make a concerted effort to grow the state FPI through targeted growth of the industry's secondary solid wood products and wood furniture sectors. Though these sectors experienced some of the most severe decreases in direct contributions over the years analyzed, as of 2017, they were still large contributors the state's overall FPI. These sectors require more highly skilled labor and were found to contribute a large number of jobs and high employee compensation relative to their output. Growth in these sectors would not only support valueadded wood products manufacturing jobs but would also increase economic activity between FPI sectors within the state and decrease the industry's reliance on exporting its primary forest products out of state. Secondly, these efforts should be targeted in the Southern and Highlands region of the state, in which the FPI was found to fare relatively better over the years analyzed. The FPI presents immense opportunity to provide badly-needed jobs in these regions and serve to induce further growth in industry activity throughout the state. 


\section{Table of Contents}

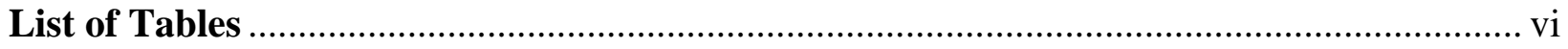

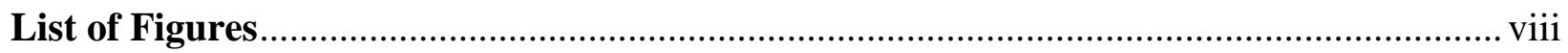

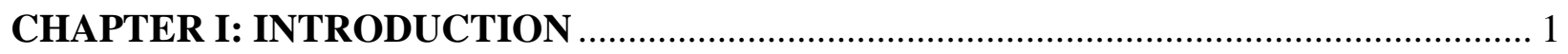

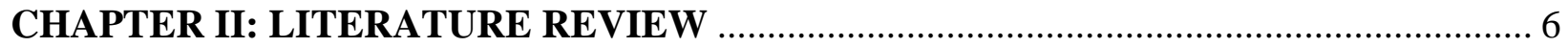

2.1 Distinctions Between Economic Impacts and Economic Contributions .................... 6

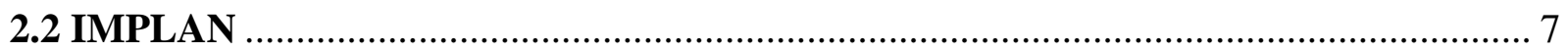

2.3 Standard Procedures for Economic Contribution Analysis of Forest Products .......... 9

2.4 Economic Contribution of the Forest Products Industry in the United States .......... 12

2.4.1 Southern United States............................................................................. 12

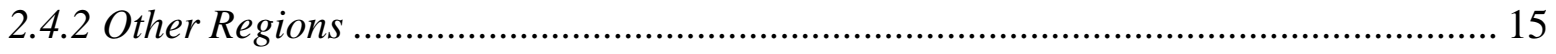

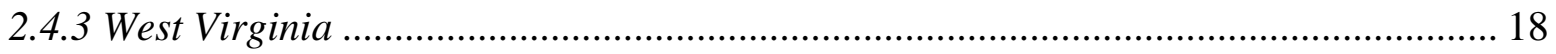

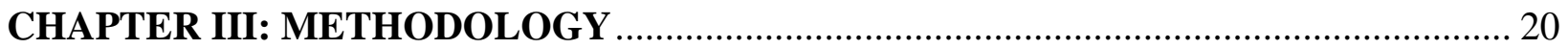

3.1 Input-Output Theoretical Model........................................................................ 20

3.2 Economic Contribution Analysis Using IMPLAN ............................................. 23

3.2.1 Economic Contribution Matrix Inversion Method (Method 2) ................................ 23

3.2.2 IMPLAN Results and Associated Multipliers .................................................... 24

3.2.3 IMPLAN Datasets and Sector Aggregation ....................................................... 26

3.2.4 Objective I - The Economic Contribution of the West Virginia FPI in 2017............. 28

3.2.5 Objective II - The Historical Economic Contribution of the West Virginia FPI ........ 29

3.2.6 Objective III - The Regional Economic Contribution of the West Virginia FPI........ 29

CHAPTER IV: RESULTS AND DISCUSSION ..................................................... 32

4.1 The Economic Contribution of the West Virginia FPI in 2017 ............................ 32

4.1.1 The Forest Products Industry ...................................................................... 32

4.1.2 The Forest Products Industry Major Sectors .......................................................... 34 
4.2 Historical Economic Contribution of the West Virginia FPI for Years 2006, 2010, 2015, and 2017

4.2.1 Changes in the West Virginia FPI: 2006, 2010, 2015, and 2017............................ 39

4.2.2 Changes in the West Virginia FPI Major Sectors: 2006, 2010, 2015, and $2017 \ldots \ldots . .44$

4.3 FPI Contributions to the Regions of West Virginia for 2006 and $2017 \ldots \ldots \ldots \ldots \ldots \ldots . . . . . . .66$

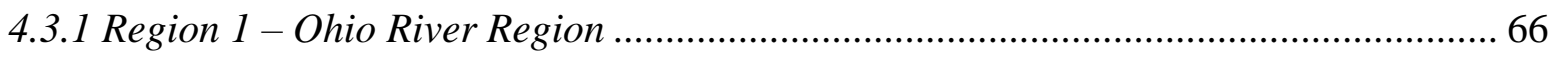

4.3.2 Region 2 - North Central Region .................................................................... 72

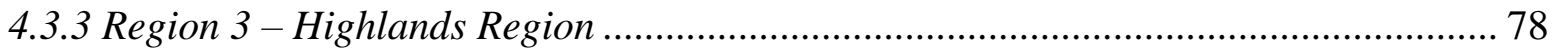

4.3.4 Region 4 - Eastern Panhandle Region ........................................................... 84

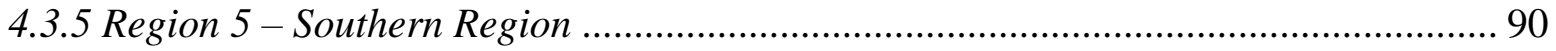

CHAPTER V: CONCLUSIONS \& RECOMMENDATIONS ........................................ 96

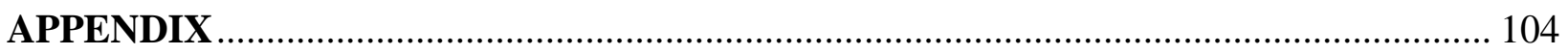

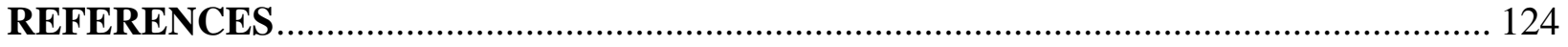




\section{List of Tables}

Table 1. FPI major sectors included in IMPLAN analysis................................................27

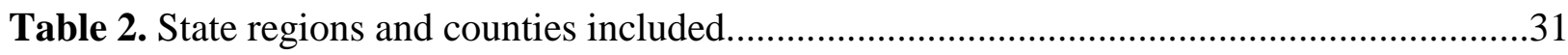

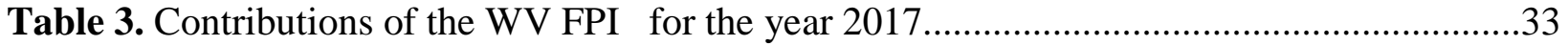

Table 4. Contributions of the WV FPI major sectors for the year 2017.................................34

Table 5. The economic contribution of the WV FPI: 2006, 2010, 2015, 2017......................42

Table 6. Changes in the contribution of the WV FPI: 2006 to 2010, 2010 to 2015,

2015 to 2017

Table 7. The economic contribution of the WV primary solid wood products sector:

2006, 2010, 2015, 2017

Table 8. Changes in the contribution of the WV primary solid wood products sector:

2006 to 2010,2010 to 2015,2015 to 2017

.46

Table 9. The economic contribution of the WV secondary solid wood products sector:

2006, 2010, 2015, 2017

Table 10. Changes in the contribution of the WV secondary solid wood products sector:

2006 to 2010,2010 to 2015,2015 to 2017 .

Table 11. The economic contribution of the WV wood furniture sector: 2006, 2010,

2015,2017

Table 12. Changes in the contribution of the WV secondary wood furniture sector:

2006 to 2010,2010 to 2015,2015 to 2017

Table 13. The economic contribution of the WV logging sector: 2006, 2010, 2015,

2017

Table 14. Changes in the contribution of the WV logging sector: 2006 to 2010,

2010 to 2015,2015 to 2017 
Table 15. The economic contribution of the WV forestry sector: 2006, 2010, 2015, 2017. .58

Table 16. Changes in the contribution of the WV forestry sector: 2006 to 2010, 2010 to 2015,2015 to 2017 .

Table 17. The economic contribution of the WV pulp, paper, and paperboard sector: 2006, 2010, 2015, 2017

Table 18. Changes in the contribution of the WV pulp, paper, and paperboard sector: 2006 to 2010,2010 to 2015,2015 to 2017 .62

Table 19. The economic contribution of the WV secondary paperboard and other paper products sector: 2006, 2010, 2015, 2017 ....... 64

Table 20. Changes in the contribution of the WV secondary paperboard and other paper products sector: 2006 to 2010,2010 to 2015,2015 to 2017 . .65

Table 21. Contributions of the Region 1 FPI for years 2006 and 2017 .67

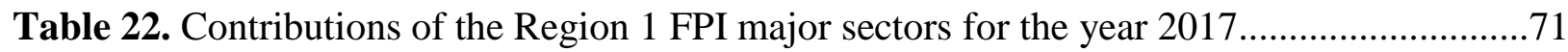

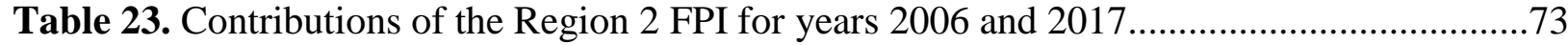

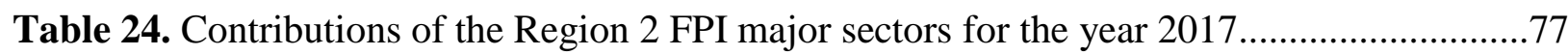

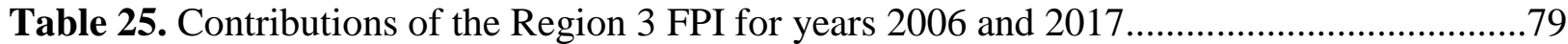

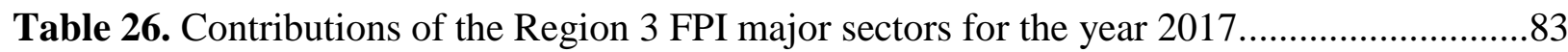

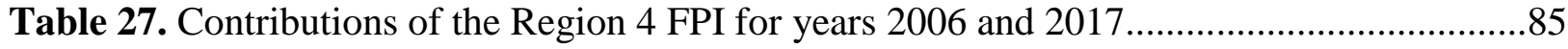

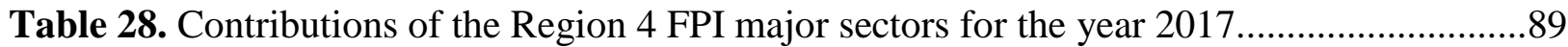

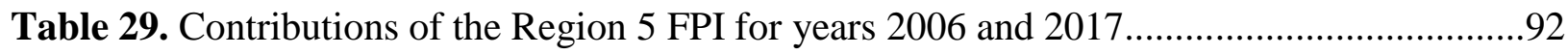

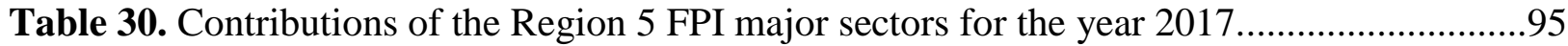




\section{List of Figures}

Figure 1. The 5 regions of the West Virginia FPI............................................................ 31

Figure 2. FPI major sector share of overall FPI direct contributions of output for

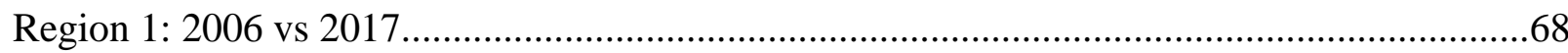

Figure 3. FPI major sector share of overall FPI direct contributions of output for

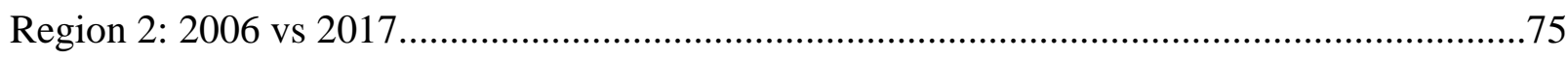

Figure 4. FPI major sector share of overall FPI direct contributions of output for

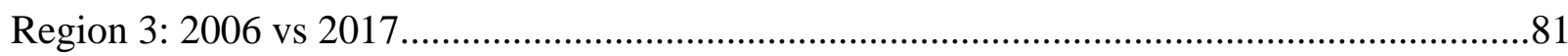

Figure 5. FPI major sector share of overall FPI direct contributions of output for

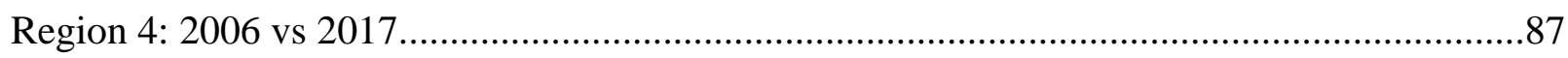

Figure 6. FPI major sector share of overall FPI direct contributions of output for

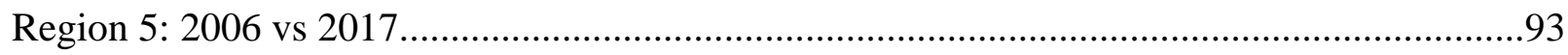




\section{CHAPTER I: INTRODUCTION}

The hardwood forests of West Virginia are a vital resource to the state and have historically played a fundamental role in its economy. West Virginia is the third most heavily forested state in the United States with over 12 million acres of forestland making up 78 percent of the state's total land area. Of these forestlands, 97 percent is classified as unreserved and productive timberlands (Morin et al., 2018). The state is situated squarely in the Appalachian Mountain section of the Central Hardwood Forest. In 2017, over 181 million $\mathrm{ft}^{3}$ of timber was harvested from the state (Morin et al., 2018). This plentiful natural resource serves as a strong foundation for a substantial forest products industry within the state. From industrial shipping pallets and paper products to household cabinetry and hardwood flooring, products derived from West Virginia hardwoods play a vital role in the broader economy. As large-diameter timber stands within the state have been steadily increasing since 1975, West Virginia's forest products sectors are primed to continue to serve the state's economy well into the future (Morn et al., 2018).

West Virginia's forest products industry (FPI) has long been viewed as an important industry to the state. However, there is currently a lack of research into the industry's contribution to the state economy. Over the past decade, assessments of the economic contribution of forestryrelated industries across the country have increased in frequency. The information gained from these analyses are often used to advocate for the industry and are a resource for those lobbying for the benefit of the industry. However, as other states with substantive forestry industries regularly perform such research, West Virginia has not kept pace with this trend. Particularly, forest economists in the Southern United States have been at the forefront of these efforts. Since 2009, multiple regional analyses that encompassed all 13 United States Forest Service Southern 
Region states have been conducted (e.g.; Dahal et al., 2009; Hodges et al., 2011; Brandeis and Hodges, 2015). In fact, analyses have been conducted on a nearly annual basis for two of the states that border West Virginia: Virginia and Kentucky (SGSF, 2019). In contrast, the last examination of the contribution of West Virginia's FPI was released in 2005 (Childs, 2005). Conducted by the West Virginia Bureau of Business and Economic Research (BBER), the report noted that, while many of the state's key industries had experienced steady declines in employment over the preceding decades, the wood products industry ran counter to that trend and was beginning to play a larger role in the state economy. The study estimated that, in 2005, the industry supported a total of nearly 30,000 jobs and $\$ 4$ billion in output annually. While many states have comparable figures for recent years, West Virginia does not have any quantitative measure of what portion of the state economy is supported by its forestry industry.

Certainly, much has changed since 2005. The United States housing market collapse of 2006 and the economic recession that followed had severe implications for the United States FPI. Mill closures and job losses were witnessed across the country. A 2011 study of the northern United States FPI estimated that, between 2006 and 2010, total employment in the three major sectors of the forest-related industry fell by approximately 28 percent, or 194,000 jobs (Woodall et al., 2011). The same study found that employment in West Virginia's wood product manufacturing sector as a percentage of overall manufacturing employment fell by nearly 8 percent over that same time. A corresponding study examining the United States South found that the region's three primary forestry sectors lost 110,000 jobs between 2005 and 2009 (Hodges et al., 2011). Somewhat narrower in focus, an examination of Eastern United States hardwood lumber production estimated that, by 2009, domestic hardwood lumber consumption declined by 43 
percent from peak levels just 10 years prior (Luppold and Bumgardner, 2016). The effects of the housing market collapse have also overshadowed longer-term trends in the United States FPI, such as the continuing offshoring of wood furniture manufacturing that began, in earnest, in the early 2000s. Simultaneously, lower domestic demand for hardwood lumber has resulted in an increasing reliance on exports of wood products to foreign markets (Luppold and Bumgardner, 2016). In more recent years, the boom in Marcellus shale drilling in the hardwood regions of the United States that began in 2007 has also had an effect on forest sector employment. Grushecky and Wang (2013) found a decrease in logging jobs in the top four counties in West Virginia involved in Marcellus shale drilling between 2009 and 2012.

Clearly, the FPI in the United States has undergone significant changes over the past two decades. The housing market collapse, subsequent recession, continued increasing global competition, natural gas boom, and other macro-economic trends call for a reexamination of the role the FPI plays in the West Virginia economy. The results of such an examination will provide much needed information to policymakers, forest industry stakeholders, private forest landowners, and others. Making this information available can only serve to benefit the industry and the health of the broader state economy.

This study therefore evaluates the economic contribution of the FPI to West Virginia's economy. Specifically, the objectives of this research are as follows:

- Objective I: Estimate the contributions of West Virginia's forest products industry to the state economy in 2017. 
- Objective II: Estimate and examine the historical economic contributions of West Virginia's forest products industry to the state economy for the years 2006, 2010, 2015, and 2017.

- Objective III: Estimate and compare the economic contributions of the forest products industry in five separate regions of West Virginia for the years 2006 and 2017.

The first objective uses the most current data available to produce an estimation of the current contribution of the FPI and its major individual sectors to the state economy. Through the use of recognized best methodological practices for economic contribution analyses, an estimation is made that is directly comparable to other states with significant forestry sectors and reproducible by future analysts. Secondly, corresponding analyses for past years give much needed information that has been missing since the last major state report released in 2005. Years have been chosen as to illustrate the effects of the United States housing collapse and subsequent recession. These results, paired with the results from the most current data, will illustrate the historical performance of the state's FPI and whether it has returned to pre-recession levels of economic activity. Lastly, this research examines the separate and distinct regions within West Virginia and the role the FPI and its major sectors have played in their economies over time. Through this regional analysis, it is made clear where in the state the major FPI sectors are centered and which regions' economies are more heavily reliant on the industry. By including a historical perspective of the regional analyses, it can illustrate how the contributions to the separate regions have changed over time and which regions FPI sectors are performing better or worse, relative to each other. This gives an added level of understanding of how the FPI is 
situated within the state economy and may provide insights into where opportunities may lie for a more productive forestry sector in West Virginia.

The completion of these objectives will lead to a comprehensive understanding of the role the FPI plays in the state economy and how that has changed over the past decade. With this information, policymakers and other state forestry stakeholders will be able to make more wellinformed decisions to better serve the industry. Furthermore, it will serve as a basis for future research that will continue to track how the contribution of the industry to the state economy continues to evolve in future years. 


\section{CHAPTER II: LITERATURE REVIEW}

\subsection{Distinctions Between Economic Impacts and Economic Contributions}

Frequently, the terms economic impact and economic contribution are used interchangeably. Over the past decade, however, an effort has been made to develop a more nuanced terminology for these types of economic analysis (Watson, 2007; Henderson et al., 2017). Making clear the distinctions between the two analyses is crucial for their results to be well understood. Economic impact analyses have been defined as those that are attempting to measure the net changes to an economy that can be attributed to a new or potential industry, event, or policy. Alternately, economic contribution analyses attempt to measure the gross existing economic activity that can be attributed to an existing industry, event, or policy (Watson, 2007). For example, if a new industry was to move into a region, measuring the effect of that event on the regional economy would be a measure of economic impact. If, on the other hand, an analyst was measuring the effect an industry has on a region in which it already exists, that would be a measure of the industry's economic contribution to that region. Making this semantic distinction is important not only to give full context to the results of such analyses, but also to establish the methodological basis of the analyses. By ignoring this distinction, the results of an analysis could be inappropriately compared to other analyses, erroneously reported, or otherwise misconstrued. The objectives of this research relate to the quantification of the economic activity that can be attributed to the FPI in West Virginia as it exists and has existed historically. Following from this, the methodological approaches associated with economic contribution analysis are appropriate. 


\subsection{IMPLAN}

Economic impact and economic contribution analyses are often conducted through the use of the Impact Analysis for Planning (IMPLAN) software. IMPLAN is based on Input-Output (I-O) analysis. Through the construction of I-O models, IMPLAN allows users to estimate the impact or contribution of potential, foregone, or existing economic activities within a user-defined region. Originally developed, in part, by the USDA Forest Service in the 1970s, it is now commercially available to non-government agencies and is privately owned and operated by IMPLAN, LLC (Henderson and Evans, 2017). The data from which IMPLAN models are built upon are derived from a number of government sources. For United States national and subnational datasets, data is gathered from the United States Department of Commerce's Bureau of Economic Analysis (BEA), the United States Bureau of Labor Statistics (BLS), and the United States Census Bureau (MIG, 2019). IMPLAN datasets are available for the United States down to the zip code level of specification. New datasets are released every year with an approximate one year lag.

The strength of the IMPLAN software lies in the ability of the user to customize and personalize their model as they see fit. The analyst begins by defining their region of analysis. A single region analysis can be performed through the use of a single IMPLAN dataset, or through the aggregation of a number of datasets into one large regional economy to be analyzed. Alternatively, a multi-regional input-output (MRIO) analysis can also be performed. An MRIO analysis allows the user to track how an industry's activity in the core region of study effects production in the economy of another interconnected (usually neighboring) region. This allows 
the analyst to not only model how the industry exists in the core region of study, but also captures any feedback linkages that may exist in other regions.

IMPLAN also offers a number of approaches with which to build a regional model. By default, the model will be built through a trade flows approach. This approach takes into account spatial factors such a proximity and size of alternative markets and is the superior method for economic contribution analyses (Henderson et al., 2017; IMPLAN, 2015). Alternative methods such supply-demand pooling and econometric regional purchase coefficient should be considered when accounting for the underlying theoretical assumptions the user has about the region. Once the region and model are customized to the user's specifications, a unique I-O model is built for the region.

IMPLAN also allows for the customization of the Social Accounting Matrix (SAM) that underlies the model. A SAM is an input-output matrix that represents the market (inter-industry) relationships that exist in an economy as well as the non-market (institutional) relationships that are present (Cheney, 2018). The inclusion of these institutions allows the SAM to not only account for the economic activity brought upon by inter-industry activity, but also that which is brought upon by institutional (e.g. household, governmental) spending. IMPLAN allows the user to choose which institutions are included in the SAM. The default setting for IMPLAN is to include households, broken down by income levels, but the analyst may choose to include other institutions as they deem appropriate. 
In any economic analysis of a specific industry, how the analyst defines the industry is particularly important. Through IMPLAN, the analyst can include or exclude any number of 536 individual sectors to define their industry of study. Each IMPLAN sector corresponds with one or more North American Industrial Classification System (NAICS) sectors (Cheney, 2018b). When defining the industry to be assessed, the user may aggregate these sectors in order to build the industry as they understand it exists in their region. IMPLAN can then model the combined economic effects of the industry rather than the effects of the individual component sectors. IMPLAN also allows for the modification of industrial accounts and purchasing patterns of individual sectors. This allows the analyst to model economic activity as they find it in their region of study based on primary data.

\subsection{Standard Procedures for Economic Contribution Analysis of Forest Products}

As assessments of the economic contribution of forest products industries for regions and states have increased in frequency in recent decades, an effort has also been made by some to produce standard procedures and methods for such analyses. A significant result of this effort was a summit held in 2015 in Little Rock, Arkansas, which was detailed by Henderson et al., (2017). Organized through the Southern Regional Extension Forestry (SREF) and the Southern Group of State Forester (SGSF), this meeting brought together 21 forest and regional economists from universities and state forestry agencies. These analysts sought out to identify and address issues with regard to the collection, calculation, and delivery of information on the economic impact and contribution analysis of forest-related industries. The summit resulted in recommendations, which prioritize making clear the assumptions and methodological procedures that are implemented in economic impact and contribution analyses of forest products sectors. They 
include making the distinction between economic contribution and economic impact analysis, reporting results in constant dollars, clearly defining reported economic measures, detailing how forestry industry sectors are defined and aggregated, and making necessary methodological disclosures, including the assumptions that have been made in constructing the input-output models used in the analyses.

Following the Little Rock summit, an additional effort to standardize economic analyses of forestry-related industries was outlined by Joshi et al. (2017). Through a survey of 69 forestry sector analysts (41 of whom completed the survey), the authors gained insights into common practices used in the economic analysis of forest products industries. Many of the analytical insights pertained to the use of the Impact Analysis for Planning, or IMPLAN, software commonly used in these analyses. Generally, the survey found that many practitioners used techniques consistent with the recommendations set forth by the Little Rock summit. According to Joshi et al. (2017), some variation in analysis methods used by responding analysts were found in the aggregation of forestry-related sectors into specific FPI categories, which institutions were made endogenous when constructing the IMPLAN model's Social Accounting Matrix (SAM), and whether or not primary data was used in conjunction with the IMPLAN estimates for the study area. Furthermore, some of the challenges identified through the survey was the need for consistent reporting among analysts as to make comparing analyses from different agencies easier and making clear the modeling assumptions used in separate analyses. As, oftentimes, the reports resulting from such analyses are directly compared to each other, the similarities and differences in the methods used by FPI analysist are crucial to understand. 
Making these distinctions clear to the users of such a report is the responsibility of the analyst and/or the author of the report.

Similar to the semantic distinctions between economic impacts and economic contributions, there are corresponding differences in methodological approach when conducting either type of analysis. Because IMPLAN was originally developed for economic impact analysis, additional steps must be taken when performing economic contribution analysis as to not produce inflated results (MIG, 2004; Parajuli et al., 2018). Two prevailing methods commonly used in economic analysis were examined by Parajuli et al. (2018). The first method, referred to as Method 1, involves adjusting the IMPLAN model itself in order to, in effect, constrain the model to make it appropriate for economic contribution analysis. After the regional I-O model is initially constructed in IMPLAN, the analyst must normalize the cross-sector commodity coefficients and nullify the local use ratios of the sectors that make up the industry of study. These adjustments to the model eliminate any feedback linkages that may exist and ensure that the resulting total output of the industry reported by IMPLAN does not exceed that which is currently estimated to exist. Method 2, also referred to as the matrix inversion method, is external to IMPLAN. This method involves the construction of a mathematical matrix built through the Social Accounting Matrix multipliers associated with the industry sectors which underly the IMPLAN model. The inverse of this matrix is then be used to downwardly adjust the values in the user inputs as industry sales that are introduced as a "shock" the IMPLAN model. Similar to Method 1, the downwardly adjusted input values ensure that the total output of the industry reported by IMPLAN does not exceed that which is currently estimated to exist (Parajuli et al., 2018; Henderson and Evans, 2017). While both methods aim to accomplish the same goal of 
preventing overestimation of the industry's contribution, Method 2 is more widely accepted in the literature. As noted by Prajuli et al. (2018), Method 2 is perceived as more rigorous and provides results which contain added detail with regard to backward linkages among sectors. For these reasons, it is appropriate to implement Method 2, or the inverse matrix approach, for the purposes of this research.

\subsection{Economic Contribution of the Forest Products Industry in the United States}

\subsubsection{Southern United States}

Forest economists in the United States South have led the way in efforts to measure the economic contribution of forest-related industries in the country. In recent decades, the increase in computing power and accessibility, paired with the commercial availability of input-output modeling systems such as IMPLAN has made conducting these reports more prevalent. Efforts coordinated by the Southern Group of State Foresters and the Southern Regional Extension Forestry have resulted in the 13 USFS Southern Region states regularly releasing such reports, often on an annual basis. Such a report was released in 2017 by the South Caroline Forestry Commission (Khanal et al., 2017). This analysis implemented the IMPLAN software to create a model of the South Carolina economy using 2015 IMPLAN data. Six forest-related sectors were created by grouping 41 individual IMPLAN sectors. The six major sectors included timber, logging, solid wood products, wood furniture, pulp and paper, and forest-based recreation and were reported in terms of value added, employment, earned income, and output. Data sourced from the BLS Quarterly Census of Employment and Wages, South Carolina Forestry Commission, and the National Survey of Fishing, Hunting, and Wildlife-Associated Recreation: South Carolina were used to augment IMPLAN data. The outside data introduced to the 
IMPLAN model were converted from retail prices to producer prices and distributed to the appropriate forest-based sectors. Additionally, retail, wholesale, and transportation expenditure data introduced were margined using the default values provided by IMPLAN. The included IMPLAN sectors of support activities for agriculture (sector 19) and forestry and commercial and industry machinery and equipment repair and maintenance (sector 507) were rescaled in order to account for only the forest-related portion of those sectors. Sector 19 was discounted by the ratio of state forestry workers to those of forestry and agriculture. Sector 507 was rescaled by the ratio of the total dollar output of all other included forestry sectors to the total value of state output. Results of direct and total contributions in terms of employment, labor income, value added, and output were given for each of the six major forest-related sectors. Their contributions were then totaled to arrive at total industry contribution figures. The contributions for each of the six major sectors were then detailed further in terms of the direct, indirect, induced, and total contributions of employment, labor income, value added, and output. Comparing their results to that of a 2006 analysis, the study finds that state total forestry sector output increased by $\$ 3.6$ billion. Likewise, it was found that labor income increased by 11 percent overall. The study notes that the largest forestry sector in the state, by far, is the pulp and paper sector as it represents over half of the state forestry sector employment, over 60 percent of value added, and two-thirds of output and any increase in overall forestry sector performance is largely attributable to the pulp and paper sector.

In addition to the assessments of forest products industries of individual states, the United States South has also led the way in terms of forestry contribution analyses with a regional approach. One early regional assessment by Aruna et al. (1997) sought to measure the economic 
contribution of the FPI of the region. Later efforts to replicate this assessment in 2007 were reported by Tilley and Munn (2007). Consisting of an analysis of 13 southern state economies, the study used IMPLAN I-O software to assess the impact of forest-related sectors in the region. The study focused on two aspect of economic contribution: (1) the jobs, income, output, and value added directly attributable to the FPI, and (2) the associated multipliers that represent the "ripple effects" that the industry creates throughout the broader economy. The product of which convey the portion of the overall economy which the FPI supports. The multipliers associated with the direct contribution of the industry are reflective of the quantities of inputs the industry requires to produce output, and the amount at which those inputs are obtained from within the study area (Tilley and Munn, 2007). Multipliers were reported for each state in the region. Averages were also reported for the measures of output, employment, value added, total income, and personal income for each of three aggregate wood products sectors: wood furniture, lumber and wood products, and paper and allied products.

In 2013, the economic contribution of the Southern region's FPI was again reexamined, this time with 2009 data, by Dahal et al., (2013). The IMPLAN software system was again used to examine the same 13 Southern states' forest products industries. Using the corresponding 2001 data, the authors compare direct contribution values and the associated multipliers, documenting the changes between the results. They found that, between 2001 and 2009, forest product industry employment decreased by 33.9 percent, while wages and salaries decreased by 4.9 percent, nominally. Between these years, the associated average state multipliers for all sectors had increased, which offset some of the decreases in direct economic contribution. As noted in 
Tilley and Munn (2007), these multipliers represent the quantity of inputs required to produce output and the ratio at which they are sourced from within the particular region of study.

\subsubsection{Other Regions}

Individual states with substantial forestry sectors also regularly produce reports on the contribution of the industry to their state economies. This increase in reporting has not been isolated to the United States South. Coronado et al. (2015) conducted one such analysis for the forestry sector of Ohio. The study used IMPLAN with 2011 data to conduct an economic contribution analysis of the forestry industry and compare to the results to that of a previous study which used data for the year 2001 (Hushak, 2005). The analysis grouped 26 individual IMPLAN sectors into 4 major FPI industry sectors consisting of forestry and logging, wood products manufacturing, paper manufacturing, and wood furniture manufacturing. Then, the direct industry measures of contribution of employment, value added, and output were used in conjunction with their associated economic multipliers to calculate the industry's total contributions. To replicate the methodology used by the previous analysis by Hushak (2005), the authors adjusted their Type SAM multipliers to discount forest products sectors' purchases from themselves to meet final demand for their output. The resulting adjusted SAM multiplier was less than or equal to the original SAM multiplier with the magnitude of decrease depending on the sector's needs for its own output. Finally, all the dollar figures for adjusted for inflation to 2011 constant dollars. The results showed that Ohio's overall FPI decreased in both absolute and relative terms of direct contribution by any of the metrics measured from 2001 to 2011 . For the industry as a whole direct output decreased by 21.9 percent, employment dropped by 33.5 percent, and value added declined by 20.0 percent. The only measure to increase between 2001 
and 2011 was forestry and logging employment which grew by 4.36 percent over the decade. The authors are not sure what to attribute this increase to and admit it may have been caused by the difficulty of capturing logging employment statistics through census methodology. However, it was the case that all the associated adjusted SAM multipliers for the industry grew from 2001 to 2011 by an average of 23 percent. Although, the increase in the economic multipliers, or the relative increase in the magnitude of the "ripple effects" made by the industry throughout the broader economy was not enough to compensate for the declines in direct contributions. The authors state that this suggests buying and selling between forestry-related sectors and nonforestry related sectors within the state increased from 2001 to 2011, essentially becoming more integrated with, and dependent on, the state's broader economy (Coronado et al., 2015).

Michigan's Department of Natural Resources (MDNR) regularly releases such reports on the economic contribution of the state's FPI. One such update was released in December 2017 (Leefers, 2017). The study used IMPLAN software paired with state level data for 2015. The study grouped 31 individual IMPLAN sectors into seven broad FPI categories: forestry; logging; primary solid wood products and wood-based power; secondary solid wood products; wood furniture; pulp, paper, and paperboard; and secondary paperboard and other paper products. Three of the individual IMPLAN sectors included in the study were only partially forestryrelated: support activity for forestry and agriculture (sector 19), institutional furniture manufacturing (sector 372), and showcase, partition, shelving, and locker manufacturing (sector 376). For these sectors, the input values entered into IMPLAN were downwardly adjusted. Support activity for forestry and agriculture was reduced to 3.9 percent of its initial values based on the percentage of employment of total employment in agriculture and forestry (NAICS 115) 
that consisted of forestry support activity employment (NAICS 1153). Institutional furniture manufacturing and showcase, partition, shelving, and locker manufacturing were reduced to the proportion of the component NAICS subsectors that were wood-based, 66.3 and 37.5 percent, respectively. The results of the analysis were reported by measures of output, employment, labor income, indirect business taxes (IBT), and value added. Direct and total contributions were reported with associated SAM multipliers for each of the seven individual FPI sectors. The direct and total contributions were then summed to reach the contributions the FPI as a whole. The report also used employment and wage data sourced directly from the United States Bureau of Labor Statistics to compare Michigan's forestry industry to those of other states and to other industries within Michigan, presenting a broad perspective on the relative contribution of the state's forestry industry (Leefers, 2017).

In 2011, a report produced by Woodall et al., (2011) took a regional perspective of the Northern United States forestry industry, which attempted to estimate the effects of the decline of the forestry industry in the region, with an emphasis on the increased downturn brought on by the United States housing market collapse of 2006 and subsequent recession. The analysis used data collected from a number of sources including the Bureau of Labor Statistics, USFS Forest Inventory Analysis, the International Trade Administration, and existing forest product economic contribution studies. Although, limited information was reported for any individual state, West Virginia's FPI was included as one of the 24 states in the analysis. The assessment found that, since 2001, the Northern FPI's three major sectors (wood product manufacturing, paper manufacturing, and furniture and related product manufacturing) had seen continual declines in employment levels leading up to the housing market collapse of 2006. Between 2005 and 2010, 
those same major forest products sectors saw total employment decline by 194,000 jobs, or 28 percent. The authors attributes some of these to longer-term trends. The heavy losses seen in the furniture manufacturing sector can be largely attributed to the large increase in the offshoring of the sector over the past decade (Woodall et al, 2011). In contrast, the industrial use sectors of wood container and pallet manufacturing sub-sectors saw relatively fewer losses in employment of a relatively small 14 percent over these same years, reflecting the continued demand for those inputs from the general manufacturing and transportation sectors. The study also notes the disproportionate decrease in mill counts in the region versus wood consumption which illustrates the increased productive capacity of mills over this period (Woodall et al., 2011).

\subsubsection{West Virginia}

An examination to the contribution of the West Virginia forestry industry to the state economy has not been conducted since 2005. Exploratory efforts for current research aside, the last assessment was conducted by Randall Childs of West Virginia University's Bureau of Business and Economic Research. The 2005 study used IMPLAN data in conjunction with data from surveys of wood products manufactures and other publicly available data to assess the economic importance of West Virginia's forests (Childs, 2005). The study was broad in scope and aimed to give a comprehensive estimation of the overall economic contribution of West Virginia's forests. While this included the contributions of non-consumption uses such as wildlife and forest recreation and forest-related tourism as well as specialty forest products such as Christmas tree farm, the economic contributions of the wood products industry were reported separately. The report found that the state's wood product sector employment had risen over the previous 25 years as other large industries in the state such as mining and non-wood manufacturing had been 
in decline. As of 2001, the wood products and furniture industries' contribution to gross state product reached 1.7 percent, up from 1.1 percent in 1990. Though the report does not detail the wood products industry's contributions by separate sectors, it does state that logging and primary and secondary wood product manufacturing in particular had been large contributors of growth for the state economy since 1980 . While stating that wood products employment had been relatively stable as compared to other industries in the state, it also found that sawmill employment in the state had peaked in 2000 and had experienced moderate declines through 2004, reflecting increasing competitive pressures. The study estimated that the total economic impact of the wood products industry to the state was just over $\$ 4$ billion in output, $\$ 2$ billion of which was contributed directly by the industry, with an additional $\$ 2$ billion in indirect and induced output. In terms of employment, the analysis found that 29,800 jobs were supported by the industry: 15,600 directly, and 14,200 through indirect and induced contributions. Total industry contributions of employee compensation were found to be $\$ 703.5$ million, with $\$ 382.6$ million being contributed directly in the industry and \$320.8 million through indirect and induced contributions. A ratio of the total and direct contributions results in multiplier values of 1.97 for output, 1.91 for employment, and 1.84 for employee compensation. This report serves as a basis for continued research into how the state's forestry industry has changed since this time. As the global and national economy has undergone severe changes since 2005 , so has the state economy. Traditionally vital industries to the state have witnessed high levels of volatility in recent years which has prompted many to call for the need for economic diversification. The continuing evolution of the state economy necessitates a reexamination of the role the FPI plays in the state. 


\section{CHAPTER III: METHODOLOGY}

\subsection{Input-Output Theoretical Model}

The prevailing method for estimating an industry's economic contribution is input-output (I-O) analysis. Developed by Nobel Laureate Wassily Leontief in the 1930s, I-O models are built upon the economic linkages that exist among the different industries within an economy. The development of a Leontief I-O model involves estimating these linkages based on observed supply chain activity with each sector being both a producer and consumer of goods. (Miller and Blair, 2009). Through these inter-industry linkages, the model is able to quantify the level of output each industry in an economy must produce in order to satisfy an estimated or given total demand for final production (Berman and Plemmons, 1979). With the increase in computing capacity over time, I-O modeling has become increasingly powerful and accessible.

In its most basic form, the Leontief I-O model is based on the separation of activities in an economy into $n$ sectors or industries. Through the observation of flows of value in the economy, transactions among the industries are then estimated. Within this framework, every sector is both a producer of goods (output) and a consumer of goods from other sectors (inputs). The interindustry transactions of value between a pair of sectors can be designated as $z_{\mathrm{ij}}$, with each sector $j$ requiring inputs from sector $i$ in order to produce sector $j$ output. The amount of inputs from sector $i$ will depend on the level of output from sector $j$ over the time period, usually a year. It should also be noted that sector $j$ will often require inputs from itself (when $i=j$ ) to produce output. This information can be illustrated through the use of an inter-industry transaction table, wherein every sector is listed as a producing sector by individual row, and a purchasing sector by individual column. Additional columns are given to account for final demand, which are sales of goods to final markets such as households and government institutions. Corresponding additional 
rows are included to account Value added which are non-industrial (or primary) inputs to production such as labor and depreciation of capital. These flows of value are illustrated in terms of monetary value, giving each sector the same basis for which to quantify the inter-industry transactions (Miller and Blair, 2009). The following designations are given:

$$
\begin{aligned}
& z_{i j}=\text { inter-industry sales by sector } i \text { to all sectors } j \\
& f_{i}=\text { final demand sales by sector } i \text { to non-industrial institutions } \\
& x_{i}=\text { total output for sector } i
\end{aligned}
$$

The data from the inter-industry transactions illustrated within the transaction table can then be used to arrive at input-output coefficients. One of the fundamental assumptions in I-O modeling is that the flow of value from sector $i$ to sector $j$ will depend on the total output of sector $j$. For example, the volume of raw logs needed by lumber manufacturers will depend entirely on how much lumber is required in order to meet total final demand. The ratio of the value of raw logs purchased by lumber manufacturers over a year and the value of lumber production over that same year, is the input-output coefficient, denoted as:

$$
a_{i j}=\frac{z_{i j}}{x_{j}}=\frac{\text { value of raw logs purchased by lumber manufacturers last year }}{\text { value of lumber production last year }}
$$

Required in I-O modeling is the assumption that the sectors use inputs in a fixed proportion. Again, referring to our lumber example, as the demand for lumber increases, the demand for raw logs increase in a fixed proportion. These coefficients can then be used to create fixed proportion production functions for each sector, which can be used to help answer the question at the basis 
of I-O analysis: how much output from each sector would be required to supply a forecasted level of final demand for a particular sector? Using the input-output coefficients we arrive at the following solution for sector output (production):

$$
\begin{array}{lc} 
& x_{1}=a_{11} x_{1}+\cdots+a_{1 i} x_{i}+\cdots+a_{1 n} x_{n}+f_{1} \\
\vdots & \\
& x_{i}=a_{i 1} x_{1}+\cdots+a_{i i} x_{i}+\cdots+a_{i n} x_{n}+f_{i} \\
\vdots & \\
& x_{n}=a_{n 1} x_{1}+\cdots+a_{n i} x_{i}+\cdots+a_{n n} x_{n}+f_{n}
\end{array}
$$

The production functions, built from the input-output coefficients, can then be represented in matrix form, $A$, known as the input-output coefficients matrix. Likewise, matrices for all industries' output and all industries' final demand can be represented by $X$ and $F$, respectively. Through matrix algebra manipulation, we may arrive at the solution for total output vector $x$ :

$$
x=(I-A)^{-1} f
$$

where $x$ is the total output vector, $I$ is an identity matrix, $A$ is the input-output coefficients matrix, and $f$ is the final demand vector. $(I-A)^{-1}$ is also referred to as the Leontief inverse, or the total requirements matrix. With this, we are able to solve for total sector output, given an estimated final demand and corresponding sector production functions 


\subsection{Economic Contribution Analysis Using IMPLAN}

\subsubsection{Economic Contribution Matrix Inversion Method (Method 2)}

The Impact Analysis for Planning (IMPLAN) economic modeling software was used for all economic contribution analysis performed. When using IMPLAN to conduct economic contribution analysis, steps must be taken as to differentiate the analysis from that of an economic impact analysis. Using economic impact analysis methods to estimate economic contribution will result in an overestimation of the economic reality through the double-counting of portions of the industry's contributions (Henderson et al., 2017). While there are two generally accepted methods for accomplishing an economic contribution analysis, this research implements the matrix-inversion method of discounting IMPLAN activity inputs. Detailed in Parajuli et al. (2018) and Henderson and Evans (2017), this method, (referred to as Method 2), is external to the IMPLAN software itself and involves downwardly adjusting sector activity inputs (entered as industry sales) before the effects of the activities are modeled by the IMPLAN software. The adjustments to the IMPLAN inputs were accomplished through obtaining the IMPLAN Social Accounting Matrix (SAM) output multipliers associated with the sectors of interest in order to create a miniature Leontief Inverse, $(I-A)^{-1}$. Inverting this obtained the $(I-A)$ matrix which was then multiplied by estimated existing industry output to arrive at the downwardly-adjusted inputs for the sectors. This downward adjustment of IMPLAN inputs ensured that the resulting total effects of the sectors of interest did not exceed that which was currently estimated to have existed (Parajuli et al., 2018; Henderson and Evans, 2017). This method also, however, requires the reported IMPLAN results to be adjusted by replacing the direct effects with original input values (Parajuli et al., 2018). 


\subsubsection{IMPLAN Results and Associated Multipliers}

The results of economic contribution analyses are reported through a number of economic measures in terms of their direct, indirect, and induced contributions.

- Direct contributions are those that are made directly by the primary industry of study's operations.

- Indirect contributions are those that arise through inter-industry activity which occur as secondary industries respond to the demand for inputs by the primary industry.

- Induced contributions are those that arise from the spending of personal income by the employees and proprietors of businesses within the primary and secondary industries.

The sum of these contributions, therefore, make up the total contribution, or the gross change in a region's economy that can be attributed to the primary industry of study (Henderson et al., 2017). The relationship between an industry's direct effects and the resulting indirect and induced effects is often represented through an associated multiplier statistic. Type I multipliers represent the relationship the industry has with the other industries within the economy and only take into account direct and indirect effects. It is calculated as follows:

$$
\text { Type I multiplier }=\frac{\text { direct effect }+ \text { indirect effect }}{\text { direct effect }}
$$

That is, Type I multipliers are representative of (1) the quantity of inputs needed for the industry to produce a unit of output, and (2) the ratio at which they are sourced from within the local economy (Tilley and Munn, 2007). For example, if the primary industry's operations demand a large amount of inputs sourced from local industries, this will result in a larger Type I multiplier. 
Conversely, if an industry sources a larger share of its inputs from outside of the local economy, this will result in a relatively smaller Type I multiplier.

Through its use of a Social Accounting Matrix (SAM), IMPLAN I-O models are built upon Type SAM multipliers, a Type II multiplier. Type SAM multipliers represent the relationship the industry has with the broader overall economy of the model region. Like Type I multipliers, they take into account the direct and indirect effects of an industry's operations, but they also include the induced effects that arise from spending of income that originates from the industry by institutions such as households or governments. Type SAM multipliers are a more comprehensive representation of the magnitude of the "ripple effects" that are created through the broader economy by the direct industry activity. They are calculated as follows:

$$
\text { Type SAM multiplier }=\frac{\text { total effect }}{\text { direct effect }}
$$

Direct, indirect, and induced effects are reported by IMPLAN for the following measures of industry-specific economic activity:

- Employment: The number of full and part time jobs

- Output: The value of industry production, or industry sales

- Value Added: The difference between an industry's output and the cost of its intermediate inputs. This consists of employee compensation, proprietor income, indirect business taxes, and other property type income. 


\subsubsection{IMPLAN Datasets and Sector Aggregation}

IMPLAN Pro version 3.1 software, paired with datasets for the state of West Virginia for the years 2006, 2010, 2015, and 2017 were used to estimate the economic contribution of the FPI to the state for those years. The datasets for 2006 and 2010 were obtained in June 2017 and had been updated and revised to reflect the 536-sector sectoring scheme as to produce results that are directly comparable with those derived from current datasets. These updated datasets also allowed for IMPLAN models to be built through the trade-flows approach. The state-level datasets also included data for individual counties, making county or regional-level analysis possible.

The FPI was defined as seven individual major forest products sectors: (1) forestry, (2) logging, (3) primary solid wood products, (4) secondary solid wood products, (5) wood furniture, (6) pulp, paper, and paperboard, and (7) secondary paperboard and other paper products (Table 1). These sectors were created in IMPLAN through the aggregation of 31 individual IMPLAN sectors and applied consistently to all analyses. In some instances, the region of study did not experience activity in all sectors. In selecting these sectors, consideration was given to the recommendations found in Joshi et al. (2017) A Synopsis of Methodological Variations in Economic Contribution Analyses for Forestry and Forest-Related Industries in the United States South. 
Table 1. FPI major sectors included in IMPLAN analysis

\begin{tabular}{|l|l|}
\hline \multicolumn{1}{|c|}{ FPI Model Sectors } & \multicolumn{1}{c|}{ IMPLAN Sectors } \\
\hline 1. Forestry (F) & $\begin{array}{l}\text { (15) Forestry, forest products, and timber tract prod.; } \\
\left(19^{*}\right) \text { Support activities for forestry }\end{array}$ \\
\hline 2. Logging (L) & $(16)$ Commercial logging \\
\hline $\begin{array}{l}\text { 3. Primary Solid Wood Products } \\
\text { (PSWP) }\end{array}$ & $\begin{array}{l}\left(47^{*}\right) \text { Electric power generation - Biomass; (134) } \\
\text { Sawmills; (135) Wood preservation; (136) Vener and } \\
\text { plywood mfg.; (138) Reconstituted wood product mfg. }\end{array}$ \\
\hline $\begin{array}{l}\text { 4. Secondary Solid Wood Products } \\
\text { (SSWP) }\end{array}$ & $\begin{array}{l}\text { (137) Engineered wood member and truss mfg.; (139) } \\
\text { Wood windows and doors mfg.; (140) Cut stock, } \\
\text { resawing lumber, and planing; (141) Other millwork, } \\
\text { including flooring; (142) Wood container and pallet } \\
\text { mfg.; (143) Manufactured home (mobile home) mfg.; } \\
(144) \text { All other miscellaneous wood product mfg. }\end{array}$ \\
\hline 5. Wood Furniture (WF) & $\begin{array}{l}\text { (368) Wood kitchen cabinet and countertop mfg.; } \\
\text { (369) Upholstered household furniture mfg.; (370) } \\
\text { Nonupholstered wood household furniture mfg.; } \\
\text { (372*) Institutional wood furniture mfg.; (373) Wood } \\
\text { office furniture mfg.; (374) Custom architectural } \\
\text { woodwork and millwork mfg.; (376*) Showcase, } \\
\text { partition, shelving, and locker mfg.* }\end{array}$ \\
\hline $\begin{array}{l}\text { 6. Pulp, Paper, and Paperboard } \\
\text { (PPP) }\end{array}$ & $\begin{array}{l}\text { (146) Pulp mills; (147) Paper mills; (148) Paperboard } \\
\text { mills. }\end{array}$ \\
\hline $\begin{array}{l}\text { 7. Secondary Paperboard and } \\
\text { other Paper Products (SPOP) }\end{array}$ & $\begin{array}{l}\text { coated and treated paper mfg.; (151) Stationary } \\
\text { product mfg.; (152) Sanitary paper product mfg.; } \\
\text { (153) All other converted paper product mfg. }\end{array}$ \\
\hline
\end{tabular}

Note: Model sector abbreviations and IMPLAN sector numbers are in parenthesis.

*Denotes partial sector inclusion

IMPLAN sectors 19, 47, 372, and 376 were each included in the analyses as partial sectors. For sectors 19, 372, and 376, North American Industry Classification System (NAICS) data were used to decrease input values in order to only account for the portion of the sectors that are forestry-related. In IMPLAN, sector 19 is listed as "Support activities for agriculture and forestry" and has 8 6-digit NAIC codes associated with it. Through the use of Bureau of Labor Statistics employment data associated with those NAICS codes for the state for each year, a 
percentage value was calculated by which to decrease input values for sector 19 as to only account for the portion of the sector that is forestry related. For sectors 372 and 376, a similar approach was taken by using NAICS data to find the proportion of employment in sectors that were considered wood-based and non-wood-based. For these sectors, however, there were no employment in the non-wood based sectors, therefore, sectors 372 and 376 are treated, essentially, as full sectors. Similarly, United States Energy Information Agency data was used to discount sector 47 values to only account for the biomass generated electric power that was produced through wood biomass. However, for the only year in which there was reported economic activity in the sector (2006), the Energy Information Agency reported no electrical generation produced with woody biomass. Therefore, sector activity could not be attributed to the FPI and the sector was not included in any of the analyses.

\subsubsection{Objective I - The Economic Contribution of the West Virginia FPI in 2017}

IMPLAN Pro version 3.1 software and the 2017 West Virginia state-level dataset were used to construct a model of the state economy. The model was constructed as a single region through the trade-flows approach. The institutions of state and local governments were made endogenous to the model, as any tax revenues received by state or local governments are to be spent within the regional (state) economy. The economic contribution of the 7 major individual forest products sectors were measured, as well as the combined contribution of the industry as a whole. Method 2, or the matrix-inversion economic contribution method, was implemented as to not overestimate industry contribution. The sectors used in the analysis included 24 of the 31 of the IMPLAN sectors outlined in Table $\mathbf{1}$ as these were the only sectors in which there was activity. Resulting direct, indirect, and induced measures of contribution were then used to determine 
corresponding Type SAM multipliers for FPI sectors as well as the industry as a whole. Industry direct contributions of state and local and federal taxes were also reported for the industry as a whole.

\subsubsection{Objective II - The Historical Economic Contribution of the West Virginia FPI}

The same methodology used in Objective I was used in the estimation of the historical economic contribution of the industry to the state. Corresponding models were constructed using the 2006, 2010, 2015, and 2017 IMPLAN state-level datasets. The 2006 and 2010 datasets had been updated and revised in order to produce results that are directly comparable to more recent IMPLAN datasets. These models were also constructed as a single region through the tradeflows approach with the institution of state government made endogenous. The matrix inversion method of discounting IMPLAN activity inputs was again implemented. The 2006 analysis included 28 of the 31 IMPLAN sectors outlined in Table $\mathbf{1}$ as they were the only sectors for which there was reported economic activity. Similarly, the 2010, 2015, and 2017 analyses included 24 of the 31 IMPLAN sectors. Resulting direct, indirect, and induced measures of contribution were reported and compared among years. Corresponding Type SAM multipliers were also calculated and compared for major FPI sectors and the industry as a whole. Direct contributions of state and local and federal taxes were also reported for the industry as a whole.

\subsubsection{Objective III - The Regional Economic Contribution of the West Virginia FPI}

To examine the economic contribution of the FPI in the distinct regions of the West Virginia, individual IMPLAN models for each identified region were created. Using the same IMPLAN software and aggregating county-level datasets, 5 individual regional models were constructed 
for each year. The regions were defined as to replicate those designated by West Virginia University's Appalachian Hardwood Center (AHC) that is being used in their annual Timber Market Report. The counties included in each of the 5 regions are detailed in Table 2 and shown in Figure 1. Once again, the economic contribution analysis Method 2 was used. Resulting direct, indirect, and induced contributions of each major FPI as well as the industry as a whole were reported with corresponding Type SAM multipliers. Industry direct contributions of state and local and federal paid were also reported. Location quotient ratios were also be reported to illustrate industry concentration for each region in terms of value added and employment and were calculated as follows:

$$
\text { Value Added LQ }=\frac{\text { Region FPI Direct Value Added } / \text { Region Total Value Added }}{\text { State FPI Direct Value Added } / \text { State Total Value Added }}
$$

$$
\text { Employment } L Q=\frac{\text { Region FPI Direct Jobs } / \text { Region Total Jobs }}{\text { State FPI Direct Jobs } / \text { State Total Jobs }}
$$


TABLE 2. State regions and counties included

\begin{tabular}{|c|c|}
\hline Region & Counties Included \\
\hline $\begin{array}{l}\text { Region } 1 \text { - Ohio River } \\
\text { Region }\end{array}$ & $\begin{array}{l}\text { Brooke, Cabell, Hancock, Jackson, Marshall, Mason, Ohio, } \\
\text { Pleasants, Putnam, Tyler, Wetzel, Wood (12) }\end{array}$ \\
\hline $\begin{array}{c}\text { Region } 2 \text { - North Central } \\
\text { Region }\end{array}$ & $\begin{array}{l}\text { Braxton, Calhoun, Clay, Doddridge, Gilmer, Harrison, Lewis, } \\
\text { Marion, Monongalia, Ritchie, Roane, Taylor, Wirt (13) }\end{array}$ \\
\hline Region 3 - Highlands Region & $\begin{array}{l}\text { Barbour, Greenbrier, Monroe, Nicholas, Pendleton, Pocahontas, } \\
\text { Preston, Randolph, Tucker, Upshur, Webster (11) }\end{array}$ \\
\hline $\begin{array}{l}\text { Region } 4 \text { - Eastern } \\
\text { Panhandle Region }\end{array}$ & $\begin{array}{l}\text { Berkeley, Grant, Hampshire, Hardy, Jefferson, Mineral, } \\
\text { Morgan (7) }\end{array}$ \\
\hline Region 5 - Southern Region & $\begin{array}{l}\text { Boone, Fayette, Kanawha, Lincoln, Logan, McDowell, Mercer, } \\
\text { Mingo, Raleigh, Summers, Wayne, Wyoming (12) }\end{array}$ \\
\hline
\end{tabular}

Note: Number of counties in parenthesis.

Figure 1. The 5 regions of the West Virginia FPI.

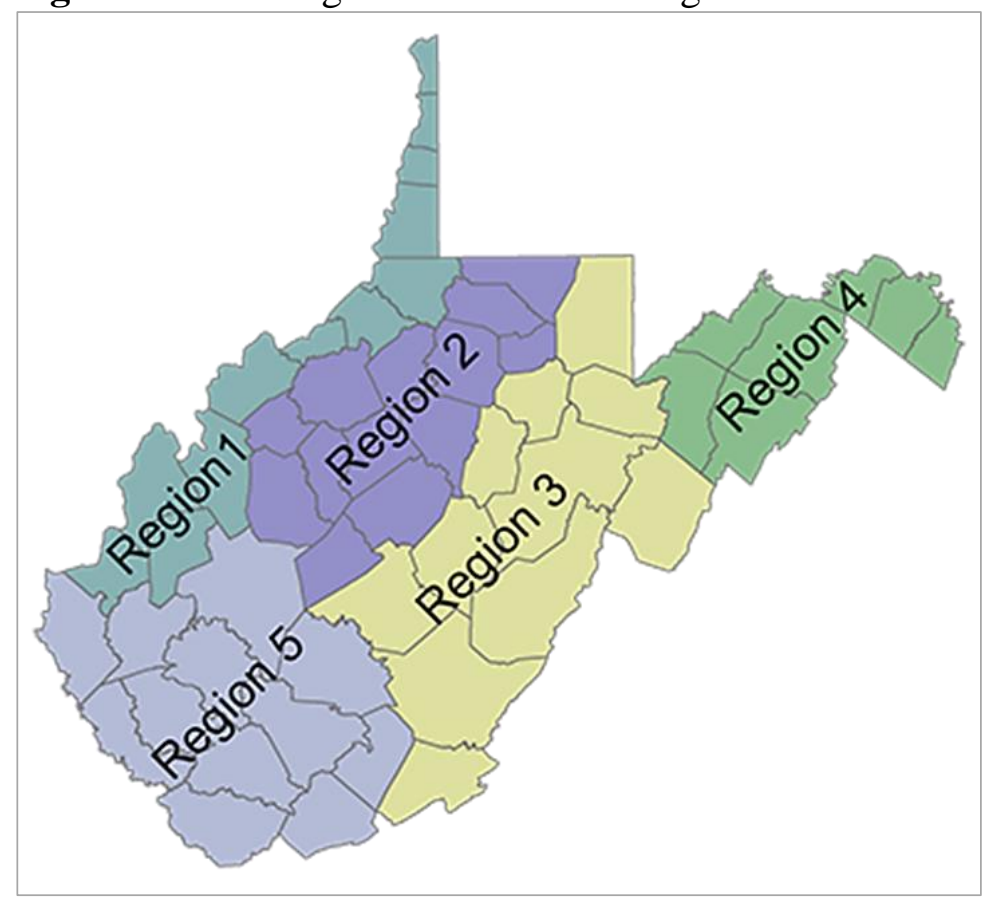




\section{CHAPTER IV: RESULTS AND DISCUSSION}

\subsection{The Economic Contribution of the West Virginia FPI in 2017}

\subsubsection{The Forest Products Industry}

The analysis of the FPI in total includes all IMPLAN sectors that define the seven major forest products sectors as defined in Table 1. In 2017, the direct contributions of the FPI in West Virginia were $\$ 2.2$ billion in output, 10,198 jobs, $\$ 750.5$ million in value added (or the industry's contribution to gross state product), and $\$ 404.5$ million in employee compensation (Table 3). The direct contribution of jobs represented 1.1 percent of all state employment and the direct contribution of value added represented 1.0 percent of gross state product. Also included in Table 3 are the indirect and induced contributions of the industry. When taking these contributions into account, the industry supported $\$ 3.4$ billion in output, 19,219 jobs, $\$ 1.4$ billion in value added, and \$764.4 million in employee compensation within the broader state economy. These total contributions of employment and value added represented 2.1 percent and 1.8 percent of the state total, respectively. The associated SAM multipliers for each measure, which illustrate the relationship between the direct contributions and the total contributions of the industry, are also listed. Although not many states or regions have publicly reported results for FPI economic contributions with 2017 data, Kentucky released a 2016 report (Stringer et al., 2018) with which some comparisons can be made. A simple ratio of 2016 direct and total contributions of the overall FPI from the Kentucky report reveal multiplier values of 2.28 for employment and 1.58 for output. These implications of these values are that, for every job contributed directly by the Kentucky FPI, 1.28 additional jobs in the broader Kentucky economy are supported. The same holds true for output: for every dollar in output directly contributed by the industry, $\$ 0.58$ in output is generated in the broader state economy. Leefers (2017) also reported SAM multiplier 
values for the Michigan FPI based on 2016 data. The associated multipliers for the overall Michigan FPI for employment and output were 2.52 and 1.77, respectively. These values compare to the West Virginia overall FPI multipliers of 1.89 for employment, and 1.54 for output for 2017. The lower multiplier values of the West Virginia economy are generally indicative of a less diverse, more rural economy. Industry direct contributions of taxes for the year were \$22.6 million in state and local taxes and 81.3 million in federal taxes.

Table 3. Contributions of the West Virginia forest products industry and associated SAM multipliers for the year 2017. Dollar amounts reported in 2017 dollars.

\begin{tabular}{|l|r|r|r|r|}
\hline $\begin{array}{c}\text { Contribution } \\
\text { Type }\end{array}$ & Output (\$MM) & Employment & $\begin{array}{c}\text { Value Added } \\
\text { (\$MM) }\end{array}$ & $\begin{array}{c}\text { Employee } \\
\text { Compensation } \\
\text { (\$MM) }\end{array}$ \\
\hline Direct & $2,218.7$ & 10,198 & 750.5 & 404.5 \\
Indirect & 856.9 & 5,025 & 460.0 & 197.6 \\
Induced & 638.2 & 5,447 & 382.0 & 203.1 \\
Total & $3,406.8$ & 19,219 & $1,429.9$ & 764.4 \\
\hline SAM Multiplier & 1.54 & 1.88 & 1.91 & 1.89 \\
\hline
\end{tabular}




\subsubsection{The Forest Products Industry Major Sectors}

Table 4. Contributions of the West Virginia FPI major sectors and associated SAM multipliers for the year 2017. Dollar amounts reported in 2017 dollars.

\begin{tabular}{|l|r|r|r|r|r|r|r|}
\hline \multicolumn{1}{|c|}{ Contribution Type } & \multicolumn{1}{c|}{ F } & \multicolumn{1}{c|}{ L } & PSWP & SSWP & WF & \multicolumn{1}{|c|}{ PPP } & \multicolumn{1}{c|}{ SPOP } \\
\hline Direct & & & & & & & \\
Output (\$MM) & 26.4 & 354.3 & 878.9 & 512.7 & 186.3 & 150.7 & 109.3 \\
Employment & 792 & 1,919 & 2,836 & 2,613 & 1,527 & 232 & 281 \\
Value Added (\$MM) & 22.7 & 312.2 & 171.3 & 152.8 & 49.5 & 21.4 & 20.5 \\
Employee Comp. (\$MM) & 17.6 & 36.3 & 132.3 & 120.3 & 66.2 & 15.8 & 16.0 \\
\hline Indirect & & & & & & & \\
Output (\$MM) & 1.8 & 19.3 & 494.2 & 231.9 & 62.5 & 79.5 & 23.4 \\
Employment & 19 & 453 & 2,776 & 1,299 & 394 & 410 & 139 \\
Value Added (\$MM) & 1.0 & 10.8 & 285.7 & 111.6 & 30.4 & 40.5 & 12.5 \\
Employee Comp. (\$MM) & 0.5 & 5.5 & 106.4 & 55.6 & 16.4 & 19.1 & 6.8 \\
\hline Induced (\$MM) & & & & & & & \\
Output (\$MM) & 20.9 & 138.1 & 263.2 & 169.0 & 70.9 & 39.2 & 22.1 \\
Employment & 176 & 1,173 & 2,257 & 1,438 & 599 & 339 & 190 \\
Value Added (\$MM) & 12.3 & 82.3 & 158.2 & 100.9 & 42.1 & 23.7 & 13.3 \\
Employee Comp. (\$MM) & 6.4 & 43.3 & 84.6 & 53.5 & 22.2 & 12.8 & 7.1 \\
\hline Total & & & & & & & \\
Output (\$MM) & 48.7 & 511.5 & $1,561.2$ & 907.0 & 319.7 & 269.2 & 154.8 \\
Employment & 977 & 3,544 & 7,598 & 5,316 & 2,519 & 980 & 609 \\
Value Added (\$MM) & 35.8 & 405.2 & 601.3 & 363.4 & 122.0 & 85.6 & 46.3 \\
Employee Comp. (\$MM) & 24.4 & 85.1 & 311.9 & 228.1 & 104.7 & 47.7 & 30.0 \\
\hline SAM Multiplier & & & & & & & \\
Output & 1.85 & 1.44 & 1.78 & 1.77 & 1.72 & 1.79 & 1.42 \\
Employment & 1.23 & 1.85 & 2.68 & 2.03 & 1.65 & 4.23 & 2.17 \\
Value Added & 1.57 & 1.30 & 3.51 & 2.38 & 2.46 & 3.99 & 2.26 \\
Employee Comp. & 1.39 & 2.34 & 2.36 & 1.90 & 1.58 & 3.01 & 1.87 \\
\hline
\end{tabular}

Primary Solid Wood Products

The primary solid wood products sector was the largest major FPI sector in terms of direct output, employment, and employee compensation (Table 4). This sector includes sawmill activity such as the productions of lumber, particle board, structural timbers, railroad ties, and other primary wood products. This sector also includes wood biomass electric power production, however, no economic activity was reported for that sector for the year. While any state with abundant forest resources is likely to have corresponding large primary wood product 
manufacturing sectors, the sizable concentration of the state's FPI in the primary solid wood products sector may reflect that large amounts of the secondary processing of the state's forest resources was taking place outside of the state. In terms of total contribution, the primary solid wood products sector was the largest by all measures. These total contributions made up 45.8 percent, 39.5 percent, 42.1 percent and 40.8 percent of the FPI total contributions of output, employment, value added, and employee compensation, respectively. SAM multiplier values for the sector were higher than those of the overall industry by every measure, particularly in the case of value added. This large multiplier value for value added is likely a reflection of the sector's inter-sector activity with the state's logging industry, which generated a large amount of direct value added. Higher multiplier values for a particular sector, in part, suggest that the sector's operations are more highly integrated with the other sectors of the state economy and, therefore, its demand for inputs generate a high level of economic activity outside of the sector itself.

\section{$\underline{\text { Secondary Solid Wood Products }}$}

The secondary solid wood products sector contributed the $2^{\text {nd }}$ highest contributions of output, employment, and employee compensation of any major FPI sector in terms of both direct and total contributions. The production of hardwood flooring, window frames, prefabricated wood buildings and other value added wood products are included in this sector. Secondary wood product manufacturing is generally more labor-intensive and requires a more highly skilled workforce. Therefore, the fact that the state's secondary solid wood products sector's direct contributions of employment and employee compensation are less than those of the primary solid wood products sector, again, suggests that much of the state's primary wood products are leaving 
the state before further value-added processing. However, the sector's share of the overall FPI's direct contributions for the year were still quite large accounting for 23.1 percent of output, 25.6 percent of employment, 20.4 percent of value added, and 29.8 percent of employee compensation. The sector's associated SAM multipliers, although higher than those of the industry as a whole, were found to be lower than those of the primary solid wood products sector by every measure. This suggests that the industry's inter-industry activity is supporting relatively lower levels of contributions of all measures than that of the primary solid wood products sector. This may be reflective of primary solid wood product firms sourcing many of their inputs from other businesses located near to where they operate, thus it is much more likely the inter-industry activity was occurring within the state, resulting in a higher multiplier value.

\section{$\underline{\text { Wood Furniture }}$}

For both direct and total contributions, the wood furniture sector ranked $4^{\text {th }}$ out the 7 major FPI sectors in terms of output, employment, and value added. Employee compensation contributed by the sector ranked $3^{\text {rd }}$ behind primary and secondary solid wood products. The relatively large direct employee compensation value is reflective of the sector's demands for a highly-skilled workforce. Direct contributions of $\$ 186.3$ million of output, 1,527 jobs, $\$ 49.5$ million in value added, and \$66.2 million in employee compensation constitute 8.4 percent, 15.0 percent, 6.6 percent, and 16.4 percent of total FPI direct contribution, respectively. Wood furniture sector SAM multiplier values were on par with FPI sector averages in the case of output and value added but were much lower in terms of employment and employee compensation. Again, this reflects the value-added manufacturing processes of the sector which require more highly-skilled labor relative to the sector's output. 


\section{$\underline{\text { Logging }}$}

The logging sector includes economic activities related to the harvesting of timber such as the cutting, processing, and transporting of timber. This sector ranks $3^{\text {rd }}$ out of 7 in terms of direct output and employment and $4^{\text {th }}$ out of seven in terms of employee compensation. However, the sector's direct contribution of value added of \$312.2 million is the highest of any major FPI sector for the year, making up 41.6 percent of the direct value added of the industry. Such a large direct contribution of value added suggests that the sector's intermediate costs associated with its operations were very low for this year, relative to the sector's sales. The fact that the sector contributed a relatively low amount of direct employee compensation shows that, despite the positive discrepancy between sales and intermediate costs, the benefits were not realized by logging sector workers. While the direct contribution of value added of the sector is large, the associated SAM multiplier of 1.30 is the second lowest of any major FPI sector by any measure for the year, resulting in the sector having the $2^{\text {nd }}$ highest ranking of total contribution of value added.

\section{Forestry}

Economic activity associated with the forestry sector includes many forest management services such as timber valuation, forest pest control activities, and fire prevention. Although crucial to the health of the state's forests, and therefore the industry as a whole, this sector's economic contribution in 2017 was relatively small when compared to the other major FPI sectors. The direct contribution of $\$ 26.4$ million in output accounted for just 1.2 percent of the total of the FPI 
as a whole, the lowest percentage of any major FPI sector for the year. Direct sector employment of 792 jobs, alternatively, made up 7.8 percent of total FPI direct employment.

\section{Pulp, Paper, and Paperboard}

The pulp, paper, and paperboard sector is made up of the three IMPLAN sectors of pulp mills, paper mills, and paperboard mills. In 2017, the sector's direct contributions of employment and employee compensation are ranked last out of the major FPI sectors. The lack of activity in this sector is due to the large pulp, paper, and paperboard mills in the region being located outside of the state: one just across the state border in Luke, Maryland and others further west in Ohio. While these mills do have concentration yards and other activity within the state to support these mills, the lack of the mills themselves leads the state to export much of its pulpwood and other sector inputs. Despite the low amount of direct contributions of the sectors within the state, large SAM multipliers represent the strong "ripple-effects" created by the sector throughout the broader state economy. The sector's employment and value added SAM multiplier values were the two largest for all FPI sectors for the year. These high multiplier values suggest that the sector's demands for inputs from within the state and the personal spending of the sector's employee and proprietors are generating a large amount of employment and value added outside of the sector. Total contributions of output, employment, value added, and employee compensation each rank $5^{\text {th }}$ out of the 7 major FPI sectors. These total contributions account for 7.9 percent of industry total output, 5.1 percent of industry total employment, 6.0 percent industry total value added, and 6.2 percent of industry total employee compensation.

\section{Secondary Paperboard and Other Paper Products}


The secondary paperboard and other paper products sector was the smallest in terms of direct output and value added, with only the forestry sector making smaller contributions for those measures. Much like the state's solid wood products sectors, the relative lack of activity in the secondary processing of pulp and paper products in the state suggests that sizeable amounts of the state's primary pulp and paper materials are being exported for value-added processing elsewhere. While growth in the sector would potentially boost broader FPI activity through its demand for inputs from other sectors in the state, the small overall size of the sector suggests there would be marginal returns on a large investments of the state's economic development resources in the sector. Unlike the pulp, paper, and paperboard sector, the associated multiplier values for the sector were below that of the industry average for all measures. IMPLAN sectors 152 (sanitary paper product manufacturing) and 153 (all other converted paper product manufacturing) did not witness any economic activity for this year.

\subsection{Historical Economic Contribution of the West Virginia FPI for Years 2006, 2010, 2015, and 2017}

\subsubsection{Changes in the West Virginia FPI: 2006, 2010, 2015, and 2017}

The contribution levels of the West Virginia FPI for the years 2006, 2010, 2015, and 2017 shown in Table 5 and the corresponding changes between the years analyzed shown in Table 6 illustrate, firstly, the immense decreases in the overall industry's contributions from 2006 to 2010. Between these years the direct contributions of the industry declined by no less than 35 percent. For comparison, Woodall et al. (2011) found that the FPI of the northern region of the United States experienced employment decline of approximately 28 percent between 2005 and 2010. Similarly, Hodges et al. (2011) found that FPI employment in the Southern United States 
decreased by more than 25 percent from 2005 to 2010. The decline in WV FPI direct contributions of employment equated to 5,337 lost jobs, or 0.6 percent of the total state employment in 2006. West Virginia FPI direct value added saw an even more dramatic decrease of 41.9 percent from 2006 to 2010 which equated to a loss of $\$ 376$ million, or 0.5 percent of 2006 gross state product. While losses were also experienced in indirect contributions of the industry, some of those losses were offset by gains in induced contribution. By every measure, induced contributions increased from 2006 to 2010. This is reflected in the growth of the associated multipliers for all measures. The growth in induced contributions implies that, although the industry witnessed considerable losses over these years, the proprietors and employees of firms within the FPI and those firms affected by FPI economic activity spent more of their income within the state. Industry direct contributions of taxes in 2006 were $\$ 28.4$ million in state and local taxes and \$122 million in federal taxes. These contributions decreased to 2010 to $\$ 19.9$ million in state and local taxes and $\$ 66.5$ million in federal taxes.

Between 2010 and 2015, the FPI increased its total contribution to the overall state economy in terms of output, jobs, value added, and employee compensation. Industry output saw the greatest relative increases between these years in terms of both direct and total contributions, reaching $\$ 2.1$ billion and $\$ 3.2$ billion, respectively. The number of jobs in the state supported by FPI activity grew by over 2,400 over these years to reach a total of 19,029 in 2015 with 10,175 of those jobs being jobs directly within the industry. Over these year, the industry's direct contribution of the total number of jobs in the state and state value added (gross state product) remained at 1.1 percent and 0.7 percent, respectively, suggesting that the industry growth over these years was on par with that of the state economy. However, in terms of total contributions 
made to the broader state economy over these years, the industry's share of state totals did increase from 1.8 percent to 2.1 percent for employment and from 1.3 percent to 1.6 percent for value added. This points to the fact that much of the growth in the overall industry took place in terms of indirect and induced contributions. In fact, overall industry direct employee compensation decreased by about 1.5\% from 2010 levels, but the increases generated through indirect and induced contributions more than compensated for these losses, resulting in an industry total contribution increase of $\$ 75.1$ million. Corresponding growth in SAM multipliers for the industry over these years continued, although slower when compared to increases from 2006 to 2010. Despite the growth between these years, the industry failed to return to 2006 levels of direct or total contributions by any measure and continued to decrease in terms of direct industry employee compensation. Direct industry contributions of taxes decreased for state and local taxes from $\$ 19.9$ million in 2010 to $\$ 17.8$ million in 2015 . Industry direct contributions of federal taxes, however, increased over this time from $\$ 66.5$ million in 2010 to $\$ 71.8$ million in 2015. 
Table 5. The historical economic contribution of the WV forest products industry and associated SAM multipliers: 2006, 2010, 2015, 2017. Dollar amounts reported in 2017 dollars.

\begin{tabular}{|l|r|r|r|r|}
\hline \multicolumn{1}{|c|}{ Contribution Type } & $\mathbf{2 0 0 6}$ & $\mathbf{2 0 1 0}$ & $\mathbf{2 0 1 5}$ & \multicolumn{1}{c|}{$\mathbf{2 0 1 7}$} \\
\hline Direct & & & & \\
$\quad$ Output (\$MM) & $2,800.0$ & $1,788.8$ & $2,122.8$ & $2,218.7$ \\
Employment & 15,018 & 9,681 & 10,175 & 10,198 \\
Value Added (\$MM) & 897.8 & 521.8 & 554.6 & 750.5 \\
Employee Comp. (\$MM) & 621.5 & 395.1 & 389.3 & 404.5 \\
\hline Indirect & & & & \\
Output (\$MM) & 862.4 & 660.4 & 824.8 & 856.9 \\
Employment & 5,632 & 5,059 & 6,074 & 5,025 \\
Value Added (\$MM) & 361.4 & 307.9 & 371.1 & 460.0 \\
Employee Comp. (\$MM) & 192.9 & 164.9 & 204.7 & 197.6 \\
\hline Induced & & & & \\
Output (\$MM) & 411.8 & 427.4 & 562.1 & 638.2 \\
Employment & 3,030 & 3,547 & 4,797 & 5,447 \\
Value Added (\$MM) & 231.5 & 257.4 & 331.5 & 382.0 \\
Employee Comp. (\$MM) & 106.3 & 128.9 & 173.3 & 203.1 \\
\hline Total & & & & \\
Output (\$MM) & $3,654.5$ & $2,644.0$ & $3,241.9$ & $3,406.8$ \\
Employment & 20,745 & 16,608 & 19,029 & 19,219 \\
Value Added (\$MM) & $1,330.1$ & 999.9 & $1,166.2$ & $1,429.9$ \\
Employee Comp. (\$MM) & 836.7 & 640.9 & 716.0 & 764.4 \\
\hline SAM Multiplier & 1.31 & 1.48 & 1.53 & 1.54 \\
Output & 1.38 & 1.72 & 1.87 & 1.88 \\
Employment & 1.48 & 1.92 & 2.10 & 1.91 \\
Value Added & 1.35 & 1.62 & 1.84 & 1.89 \\
Employee Comp. & & & & \\
\hline
\end{tabular}


Table 6. Changes in the contribution of the WV forest products industry and associated changes in SAM multipliers: 2006 to 2010, 2010 to 2015, 2015 to 2017. Dollar amounts reported in 2017 dollars. Percentages represent changes in contribution levels.

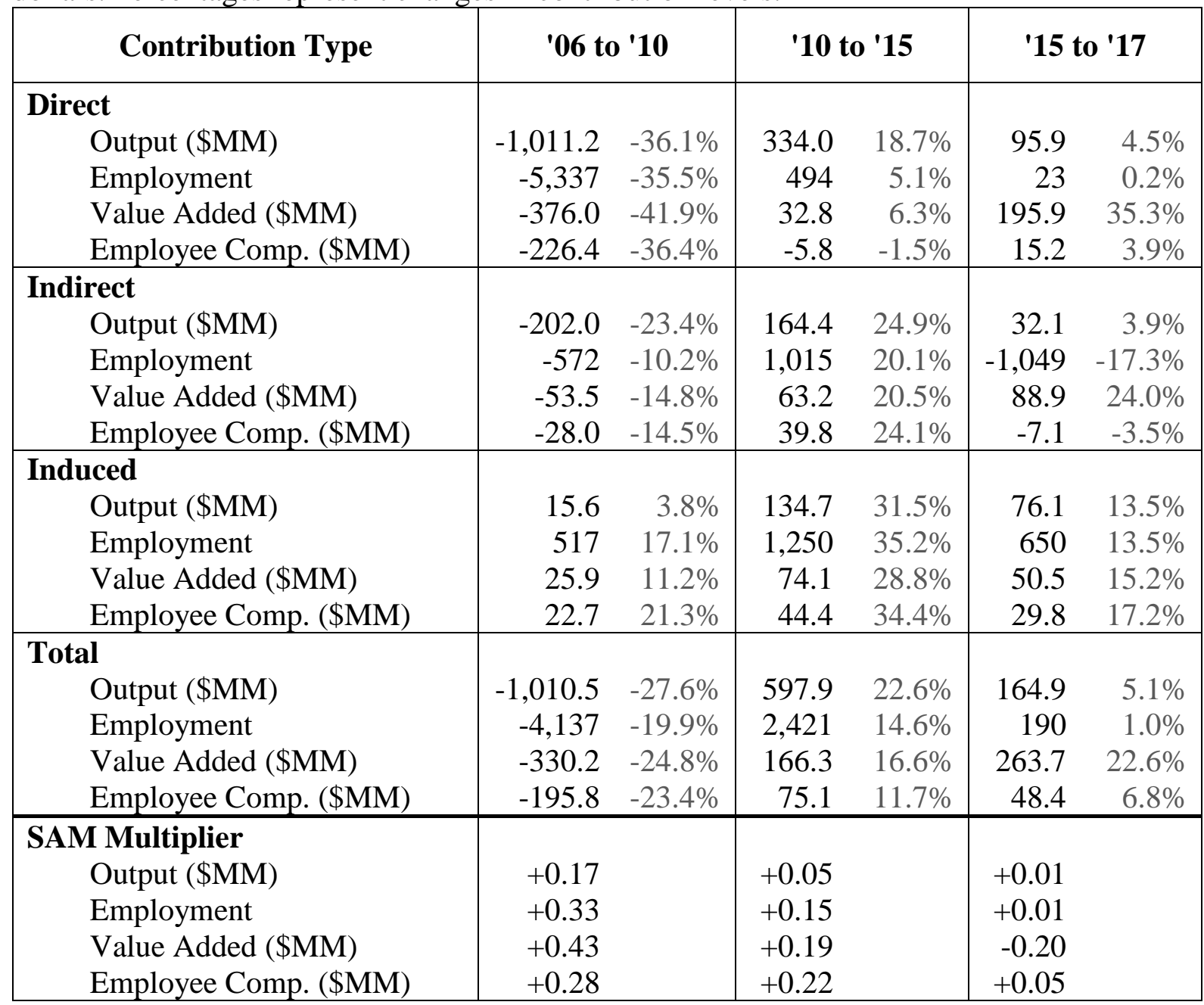

From 2015 to 2017, the FPI in West Virginia experienced limited increases in contribution levels of sales, jobs, and employee compensation. However, the industry's direct contributions of value added grew substantially over this period, increasing by 35.3 percent. This resulted in industry direct value added accounting for 1.0 percent of the gross state product in 2017, up from 0.7 percent in 2015. The increase in value added that was not also seen in terms of output, employment, and employee compensation points to a decrease in the industry's intermediate 
inputs between these years. Multiplier values grew for all measures except value added which saw a significant drop, however, not enough to fully stifle overall increases of every contribution type. In 2017 the West Virginia FPI directly contributed \$2.2 billion in output, 10,198 jobs, $\$ 750.5$ million to the gross state product, and $\$ 404.5$ million in employee compensation. In total, the changes in industry economic contribution resulted in 2017 direct contributions still well below 2006 levels and total contributions increasing only in terms of value added from 2006 to 2017. FPI direct contributions of taxes increased from 2015 to 2017 from $\$ 17.8$ million to $\$ 22.6$ million in state and local taxes and from $\$ 71.7$ million to $\$ 81.3$ million in federal taxes.

\subsubsection{Changes in the West Virginia FPI Major Sectors: 2006, 2010, 2015, and 2017}

\section{Primary Solid Wood Products}

In 2006, the primary solid wood products sector was the largest FPI sector in terms of direct output and the largest sector by all measures of total contribution (Table 7). The sector experienced substantial losses in direct and total contributions from 2006 to 2010 (Table 8), however, the losses were less severe than those experienced in the secondary solid wood products sector and less severe than those of the overall industry. The ability of the sector to avoid some of the more severe losses experienced in the broader FPI suggests that the industry shifted into more primary wood product manufacturing between these years. This is also seen in the increases of the sector's share of overall industry direct contributions between 2006 and 2010 for all measures of contribution. 
Table 7. The historical economic contribution of the WV primary solid wood products sector and associated SAM multipliers: 2006, 2010, 2015, 2017. Dollar amounts reported in 2017 dollars.

\begin{tabular}{|l|r|r|r|r|}
\hline \multicolumn{1}{|c|}{ Contribution Type } & \multicolumn{1}{c|}{$\mathbf{2 0 0 6}$} & \multicolumn{1}{c|}{$\mathbf{2 0 1 0}$} & \multicolumn{1}{c|}{$\mathbf{2 0 1 5}$} & \multicolumn{1}{c|}{$\mathbf{2 0 1 7}$} \\
\hline Direct & & & & \\
Output (\$MM) & $1,037.8$ & 747.9 & 910.0 & 878.9 \\
Employment & 4,252 & 2,990 & 3,006 & 2,836 \\
Value Added (\$MM) & 285.6 & 166.9 & 181.4 & 171.3 \\
Employee Comp. (\$MM) & 209.3 & 140.2 & 130.9 & 132.3 \\
\hline Indirect & & & & \\
Output (\$MM) & 479.7 & 365.2 & 459.9 & 494.2 \\
Employment & 3,357 & 2,905 & 3,645 & 2,776 \\
Value Added (\$MM) & 207.3 & 174.1 & 212.0 & 285.7 \\
Employee Comp. (\$MM) & 103.7 & 89.8 & 114.7 & 106.4 \\
\hline Induced & & & & \\
Output (\$MM) & 175.2 & 189.3 & 253.8 & 263.2 \\
Employment & 1,296 & 1,577 & 2,173 & 2,257 \\
Value Added (\$MM) & 98.8 & 114.3 & 150.1 & 158.2 \\
Employee Comp. (\$MM) & 45.7 & 57.6 & 78.8 & 84.6 \\
\hline Total & & & & \\
Output (\$MM) & $1,597.0$ & $1,239.2$ & $1,545.9$ & $1,561.2$ \\
Employment & 8,493 & 7,202 & 8,542 & 7,598 \\
Value Added (\$MM) & 566.5 & 441.8 & 529.1 & 601.3 \\
Employee Comp. (\$MM) & 340.1 & 276.2 & 313.4 & 311.9 \\
\hline SAM Multiplier & & & & \\
Output & 1.54 & 1.66 & 1.70 & 1.78 \\
Employment & 2.00 & 2.41 & 2.84 & 2.68 \\
Value Added & 1.98 & 2.65 & 2.92 & 3.51 \\
Employee Comp. & 1.63 & 1.97 & 2.39 & 2.36 \\
\hline ( & & & \\
\end{tabular}


Table 8. Changes in the contribution of the WV primary solid wood products sector and associated changes in SAM multipliers: 2006 to 2010, 2010 to 2015, 2015 to 2017. Dollar amounts reported in 2017 dollars. Percentages represent changes in contribution levels.

\begin{tabular}{|l|rr|rr|rr|}
\hline \multicolumn{1}{|c|}{ Contribution Type } & \multicolumn{2}{|c|}{$\mathbf{0 6}$ to '10 } & '10 to '15 & '15 to '17 \\
\hline Direct & & & & & & \\
$\quad$ Output (\$MM) & -289.9 & $-27.9 \%$ & 162.1 & $21.7 \%$ & -31.0 & $-3.4 \%$ \\
Employment & $-1,262$ & $-29.7 \%$ & 16 & $0.5 \%$ & -170 & $-5.7 \%$ \\
Value Added (\$MM) & -118.7 & $-41.6 \%$ & 14.5 & $8.7 \%$ & -10.1 & $-5.6 \%$ \\
$\quad$ Employee Comp. (\$MM) & -69.0 & $-33.0 \%$ & -9.3 & $-6.6 \%$ & 1.4 & $1.0 \%$ \\
\hline Indirect & & & & & & \\
Output (\$MM) & -114.5 & $-23.9 \%$ & 94.7 & $25.9 \%$ & 34.3 & $7.5 \%$ \\
Employment & -453 & $-13.5 \%$ & 740 & $25.5 \%$ & -869 & $-23.9 \%$ \\
Value Added (\$MM) & -33.2 & $-16.0 \%$ & 38.0 & $21.8 \%$ & 73.6 & $34.7 \%$ \\
Employee Comp. (\$MM) & -13.9 & $-13.4 \%$ & 24.9 & $27.7 \%$ & -8.3 & $-7.3 \%$ \\
\hline Induced & & & & & & \\
Output (\$MM) & 14.1 & $8.1 \%$ & 64.5 & $34.1 \%$ & 9.5 & $3.7 \%$ \\
Employment & 281 & $21.7 \%$ & 596 & $37.8 \%$ & 84 & $3.9 \%$ \\
Value Added (\$MM) & 15.5 & $15.7 \%$ & 35.7 & $31.3 \%$ & 8.1 & $5.4 \%$ \\
Employee Comp. (\$MM) & 11.9 & $26.0 \%$ & 21.2 & $36.9 \%$ & 5.8 & $7.3 \%$ \\
\hline Total & & & & & & \\
Output (\$MM) & -357.8 & $-22.4 \%$ & 306.7 & $24.8 \%$ & 15.2 & $1.0 \%$ \\
Employment & $-1,291$ & $-15.2 \%$ & 1.340 & $18.6 \%$ & -944 & $-11.0 \%$ \\
Value Added (\$MM) & -124.7 & $-22.0 \%$ & 87.3 & $19.8 \%$ & 72.2 & $13.7 \%$ \\
Employee Comp. (\$MM) & -63.9 & $-18.8 \%$ & 37.2 & $13.5 \%$ & -1.5 & $-0.5 \%$ \\
\hline SAM Multiplier & & & & & & \\
Output & +0.12 & & +0.04 & & +0.08 & \\
Employment & +0.41 & & +0.43 & & -0.16 & \\
Value Added & +0.66 & & +0.27 & & +0.59 & \\
Employee Comp. & +0.34 & & +0.42 & & -0.04 & \\
\hline
\end{tabular}

In 2010, the sector was the industry's largest contributor of overall FPI direct contributions by all measures, contributing 41.8 percent, 30.9 percent, 32 percent, and 35.5 percent of the industry's direct contributions of output, employment, value added, and employee compensation for the year. As was the case for all individual FPI sectors over this period, associated SAM multiplier values grew over this time. As in 2006, the sector's 2010 SAM multiplier values were higher than those of the industry overall. Dahal et al. (2015) reported lumber and wood products sector 
SAM multipliers for 13 US Southern states in 2009, of which the averages were 2.05 for output, 2.53 for employment, and 2.49 for value added. These compare to $2010 \mathrm{WV}$ primary solid wood product sector values of 1.66 for output, 2.41 for employment, and 2.65 for value added and 2010 WV secondary solid wood product sector values of 1.68 for output, 1.81 for employment, and 2.09 for value added. The sector saw significant growth in contributions from 2010 to 2015 . By only one measure, direct employee compensation, were the contributions of the sector less than those in 2010. The largest absolute gains in output in the industry were seen in this sector, which grew by $\$ 162.1$ million to reach a 2015 level of $\$ 910$ million, or 42.9 percent of total FPI direct output for the year. Much like the industry as a whole, many of the gains in the primary and secondary solid wood products sectors were found in the indirect and induced contributions of the sectors. From 2015 to 2017, the sector remained the industry's largest contributor of direct output, employment, and employee compensation. This was despite slight decreases in direct sector output and employment, and only a marginal growth in employee compensation over these years. SAM multiplier values for employment and employee compensation also fell, making the sector one of only two FPI sectors to experience decreases in multiple SAM multipliers over this time.

\section{Secondary Solid Wood Products}

Many of the largest losses within the West Virginia FPI between 2006 and 2010 took place in the secondary solid wood products sector. Direct contribution of value added had the largest percentage decrease from 2006 to 2010 of $\$ 152.1$ million, or 52 percent of 2006 levels (Table 10). Similarly, direct output fell by 48.9 percent, direct employment fell by 43.2 percent, and employee compensation fell by 43.6 percent. The losses in this sector were the largest in absolute 
terms between these years by all measures of direct and total contribution. This loss of valueadded wood product manufacturing affected the broader state FPI through the loss of the sector's demands for inputs from the logging and primary solid wood products sectors. This loss of intersector activity also effected the broader state economy. The decreases in the sector's total contributions to the economy resulted in the loss of 2,631 jobs, over $\$ 540$ million in output, $\$ 193.4$ million in value added and \$113.5 million in employee compensation. Despite these heavy losses, secondary solid wood products continued to be an important sector to the industry in 2010 and ranked as the $2^{\text {nd }}$ largest sector in terms of direct and total contributions of all measures behind the primary solid wood products sector. 
Table 9. The historical economic contribution of the WV secondary solid wood products sector and associated SAM multipliers: 2006, 2010, 2015, 2017. Dollar amounts reported in 2017 dollars.

\begin{tabular}{|l|r|r|r|r|}
\hline \multicolumn{1}{|c|}{ Contribution Type } & $\mathbf{2 0 0 6}$ & $\mathbf{2 0 1 0}$ & $\mathbf{2 0 1 5}$ & $\mathbf{2 0 1 7}$ \\
\hline Direct & & & & \\
Output (\$MM) & 853.1 & 436.1 & 548.1 & 512.7 \\
Employment & 4,792 & 2,721 & 2,747 & 2,613 \\
Value Added (\$MM) & 292.3 & 140.2 & 169.8 & 152.8 \\
Employee Comp. (\$MM) & 213.6 & 120.5 & 120.9 & 120.3 \\
\hline Indirect & & & & \\
Output (\$MM) & 290.2 & 177.4 & 227.6 & 231.9 \\
Employment & 1,763 & 1,181 & 1,459 & 1,299 \\
Value Added (\$MM) & 116.9 & 78.6 & 97.1 & 111.6 \\
Employee Comp. (\$MM) & 68.2 & 45.5 & 56.1 & 55.6 \\
\hline Induced & & & & \\
Output (\$MM) & 146.7 & 125.9 & 170.1 & 169.0 \\
Employment & 1,075 & 1,040 & 1,448 & 1,438 \\
Value Added (\$MM) & 82.3 & 75.6 & 100.1 & 100.9 \\
Employee Comp. (\$MM) & 37.5 & 37.6 & 52.1 & 53.5 \\
\hline Total & & & & \\
Output (\$MM) & $1,274.5$ & 734.5 & 939.1 & 907.0 \\
Employment & 7,544 & 4,912 & 5,621 & 5,316 \\
Value Added (\$MM) & 486.2 & 292.9 & 364.8 & 363.4 \\
Employee Comp. (\$MM) & 315.9 & 202.4 & 227.8 & 228.1 \\
\hline SAM Multiplier & & & & \\
Output & 1.49 & 1.68 & 1.71 & 1.77 \\
Employment & 1.57 & 1.81 & 2.05 & 2.03 \\
Value Added & 1.66 & 2.09 & 2.15 & 2.38 \\
Employee Comp. & 1.48 & 1.68 & 1.88 & 1.90 \\
\hline 年
\end{tabular}


Table 10. Changes in the contribution of the WV secondary solid wood products sector and associated changes in SAM multipliers: 2006 to 2010, 2010 to 2015, 2015 to 2017. Dollar amounts reported in 2017 dollars. Percentages represent changes in contribution levels.

\begin{tabular}{|l|rr|rr|rr|}
\hline \multicolumn{1}{|c|}{ Contribution Type } & '06 to '10 & '10 to '15 & '15 to '17 \\
\hline Direct & & & & & & \\
$\quad$ Output (\$MM) & -417.0 & $-48.9 \%$ & 111.9 & $25.7 \%$ & -35.4 & $-6.5 \%$ \\
Employment & $-2,071$ & $-43.2 \%$ & 26 & $1.0 \%$ & -135 & $-4.9 \%$ \\
$\quad$ Value Added (\$MM) & -152.1 & $-52.0 \%$ & 29.6 & $21.1 \%$ & -17.0 & $-10.0 \%$ \\
Employee Comp. (\$MM) & -93.1 & $-43.6 \%$ & 0.4 & $0.3 \%$ & -0.6 & $-0.5 \%$ \\
\hline Indirect & & & & & & \\
Output (\$MM) & -112.8 & $-38.9 \%$ & 50.2 & $28.3 \%$ & 4.3 & $1.9 \%$ \\
Employment & -582 & $-33.0 \%$ & 277 & $23.5 \%$ & -160 & $-10.9 \%$ \\
Value Added (\$MM) & -38.3 & $-32.7 \%$ & 18.4 & $23.5 \%$ & 14.5 & $14.9 \%$ \\
Employee Comp. (\$MM) & -22.7 & $-33.3 \%$ & 10.6 & $23.4 \%$ & -0.5 & $-0.9 \%$ \\
\hline Induced & & & & & & \\
Output (\$MM) & -20.9 & $-14.2 \%$ & 44.3 & $35.2 \%$ & -1.1 & $-0.7 \%$ \\
Employment & -35 & $-3.3 \%$ & 408 & $39.3 \%$ & -10 & $-0.7 \%$ \\
Value Added (\$MM) & -6.7 & $-8.1 \%$ & 24.5 & $32.4 \%$ & 0.8 & $0.8 \%$ \\
Employee Comp. (\$MM) & 0.1 & $0.3 \%$ & 14.5 & $38.5 \%$ & 1.4 & $2.7 \%$ \\
\hline Total & & & & & & \\
Output (\$MM) & -540.0 & $-42.4 \%$ & 204.6 & $27.9 \%$ & -32.1 & $-3.4 \%$ \\
Employment & $-2,631$ & $-34.9 \%$ & 709 & $14.4 \%$ & -305 & $-5.4 \%$ \\
Value Added (\$MM) & -193.4 & $-39.8 \%$ & 72.0 & $24.6 \%$ & -1.4 & $-0.4 \%$ \\
Employee Comp. (\$MM) & -113.5 & $-35.9 \%$ & 25.4 & $12.5 \%$ & 0.3 & $0.1 \%$ \\
\hline SAM Multiplier & & & & & & \\
Output & +0.19 & & +0.03 & & +0.06 & \\
Employment & +0.23 & & +0.24 & & -0.01 & \\
Value Added & +0.43 & & +0.06 & & +0.23 & \\
Employee Comp. & +0.20 & & +0.20 & & +0.01 & \\
\hline
\end{tabular}

Alternately, from 2010 to 2015, the sector was the only individual FPI sector to experience growth in direct and total contributions of every measure. By 2015, secondary solid wood products direct output and value added grew by 25.7 percent and 21.1 percent from 2010 levels, respectively. Gains in direct employment and employee compensation were much lower with just 1 percent and 0.3 percent increases, respectively. The sector's recovery did not continue through 2017, however, as it experienced across-the-board decreases in all measures of direct contribution between 2015 and 2017. As with the primary solid wood products sector, increases 
in indirect contributions of output and value added and continued growth of sector induced contributions offset some of the losses in direct contribution. In 2017, the sector was the second largest contributor of output, employment, and employee compensation in the industry and third largest contributor of value added, behind the primary solid wood products and logging sectors. The losses in the state's secondary solid wood products sector has immense consequences for the industry as a whole. The inability of the sector to regain its footing in recent years is even more troubling. As the sector continues to struggle, primary solid wood product manufacturers and other FPI sectors are increasingly dependent on business with secondary wood product manufacturers outside of the state, which results in further loss of overall economic contribution for the state.

\section{$\underline{\text { Wood Furniture }}$}

The wood furniture sector witnessed the $2^{\text {nd }}$ greatest percentage losses in direct and total contributions between 2006 and 2010 for every measure except output in which it had the highest. Losses in the broader wood furniture sector were largely attributed to the decline in housing construction and the longer term trend of offshoring of secondary wood processing (Woodall et al., 2018). Between 2006 and 2010, the wood furniture and secondary solid wood products sectors were the only two sectors to lose larger percentages of all of their direct contributions than the industry itself. Although the wood furniture sector experienced smaller losses in absolute terms than those of the primary solid wood products sector, the wood furniture sector's loss of total contributions to the broader state economy were still substantial with 1,029 jobs being lost, as well as a $\$ 163.7$ million decrease in sales (Table 12). Dahal et al. (2015) reported wood furniture sector SAM multipliers for 13 US Southern states in 2009 of which the 
averages were 1.88 for output, 2.06 for employment, and 2.32 for value added. Corresponding values for the sector in West Virginia in 2010 were 1.63 for output, 1.50 for employment, and 1.78 for value added. By 2015, these values had grown to 1.68 for output, 1.61 for employment, and 2.24 for value added, all still below the state averages reported by Dahal et al. (2015) for the year 2009.

Table 11. The historical economic contribution of the WV wood furniture sector and associated SAM multipliers: 2006, 2010, 2015, 2017. Dollar amounts reported in 2017 dollars.

\begin{tabular}{|c|c|c|c|c|}
\hline Contribution Type & 2006 & 2010 & 2015 & 2017 \\
\hline \multicolumn{5}{|l|}{ Direct } \\
\hline Output (\$MM) & 271.1 & 134.4 & 166.2 & 186.3 \\
\hline Employment & 2,224 & 1,302 & 1,408 & 1,527 \\
\hline Value Added (\$MM) & 112.0 & 59.5 & 48.1 & 49.5 \\
\hline Employee Comp. (\$MM) & 90.1 & 54.4 & 55.5 & 66.2 \\
\hline \multicolumn{5}{|l|}{ Indirect } \\
\hline Output (\$MM) & 59.0 & 37.1 & 51.6 & 62.5 \\
\hline Employment & 371 & 257 & 336 & 394 \\
\hline Value Added (\$MM) & 25.5 & 17.8 & 23.5 & 30.4 \\
\hline Employee Comp. (\$MM) & 14.5 & 9.9 & 13.4 & 16.4 \\
\hline \multicolumn{5}{|l|}{ Induced } \\
\hline Output (\$MM) & 53.2 & 48.0 & 62.2 & 70.9 \\
\hline Employment & 387 & 394 & 525 & 599 \\
\hline Value Added (\$MM) & 29.7 & 28.7 & 36.4 & 42.1 \\
\hline Employee Comp. (\$MM) & 13.5 & 14.2 & 18.8 & 22.2 \\
\hline \multicolumn{5}{|l|}{ Total } \\
\hline Output (\$MM) & 383.2 & 219.5 & 279.8 & 319.7 \\
\hline Employment & 2,982 & 1,953 & 2,270 & 2,519 \\
\hline Value Added (\$MM) & 167.2 & 106.0 & 107.9 & 122.0 \\
\hline Employee Comp. (\$MM) & 118.0 & 78.5 & 87.6 & 104.7 \\
\hline \multicolumn{5}{|l|}{ SAM Multiplier } \\
\hline Output & 1.41 & 1.63 & 1.68 & 1.72 \\
\hline Employment & 1.34 & 1.50 & 1.61 & 1.65 \\
\hline Value Added & 1.49 & 1.78 & 2.24 & 2.46 \\
\hline Employee Comp. & 1.31 & 1.44 & 1.58 & 1.58 \\
\hline
\end{tabular}


Table 12. Changes in the contribution of the WV secondary wood furniture sector and associated changes in SAM multipliers: 2006 to 2010, 2010 to 2015, 2015 to 2017. Dollar amounts reported in 2017 dollars. Percentages represent changes in contribution levels.

\begin{tabular}{|c|c|c|c|c|c|c|}
\hline Contribution Type & \multicolumn{2}{|c|}{ '06 to '10 } & \multicolumn{2}{|c|}{ '10 to '15 } & \multicolumn{2}{|c|}{ '15 to '17 } \\
\hline $\begin{array}{l}\text { Output (\$MM) } \\
\text { Employment } \\
\text { Value Added (\$MM) } \\
\text { Employee Comp. }(\$ M M)\end{array}$ & $\begin{array}{r}-136.6 \\
-922 \\
-52.4 \\
-35.7\end{array}$ & $\begin{array}{l}-50.4 \% \\
-41.4 \% \\
-46.8 \% \\
-39.6 \%\end{array}$ & $\begin{array}{r}31.8 \\
106 \\
-11.4 \\
1.1\end{array}$ & $\begin{array}{r}23.6 \% \\
8.1 \% \\
-19.2 \% \\
2.1 \%\end{array}$ & $\begin{array}{r}20.1 \\
118 \\
1.4 \\
10.6\end{array}$ & $\begin{array}{r}12.1 \% \\
8.4 \% \\
3.0 \% \\
19.2 \%\end{array}$ \\
\hline $\begin{array}{l}\text { Indirect } \\
\text { Output (\$MM) } \\
\text { Employment } \\
\text { Value Added (\$MM) } \\
\text { Employee Comp. (\$MM) }\end{array}$ & $\begin{array}{r}-21.9 \\
-115 \\
-7.7 \\
-4.6\end{array}$ & $\begin{array}{l}-37.1 \% \\
-30.8 \% \\
-30.3 \% \\
-31.5 \%\end{array}$ & $\begin{array}{r}14.4 \\
79 \\
5.7 \\
3.5\end{array}$ & $\begin{array}{l}38.9 \% \\
30.9 \% \\
32.0 \% \\
34.8 \%\end{array}$ & $\begin{array}{r}11.0 \\
58 \\
6.9 \\
3.0\end{array}$ & $\begin{array}{l}21.3 \% \\
17.1 \% \\
29.5 \% \\
22.2 \%\end{array}$ \\
\hline $\begin{array}{l}\text { Induced } \\
\text { Output (\$MM) } \\
\text { Employment } \\
\text { Value Added (\$MM) } \\
\text { Employee Comp. (\$MM) }\end{array}$ & $\begin{array}{r}-5.2 \\
7 \\
-1.0 \\
0.7\end{array}$ & $\begin{array}{r}-9.8 \% \\
1.9 \% \\
-3.4 \% \\
5.6 \% \\
\end{array}$ & $\begin{array}{r}14.2 \\
131 \\
7.6 \\
4.6\end{array}$ & $\begin{array}{l}29.5 \% \\
33.2 \% \\
26.6 \% \\
32.1 \%\end{array}$ & $\begin{array}{r}8.7 \\
74 \\
5.7 \\
3.4\end{array}$ & $\begin{array}{l}14.0 \% \\
14.0 \% \\
15.7 \% \\
18.1 \%\end{array}$ \\
\hline $\begin{array}{l}\text { Total } \\
\text { Output (\$MM) } \\
\text { Employment } \\
\text { Value Added (\$MM) } \\
\text { Employee Comp. }(\$ M M) \\
\end{array}$ & $\begin{array}{r}-163.7 \\
-1,028 \\
-61.2 \\
-39.5 \\
\end{array}$ & $\begin{array}{l}-42.7 \% \\
-34.5 \% \\
-36.6 \% \\
-33.5 \% \\
\end{array}$ & $\begin{array}{r}60.3 \\
316 \\
1.9 \\
9.2 \\
\end{array}$ & $\begin{array}{r}27.5 \% \\
16.2 \% \\
1.8 \% \\
11.7 \% \\
\end{array}$ & $\begin{array}{r}39.9 \\
249 \\
14.1 \\
17.0 \\
\end{array}$ & $\begin{array}{l}14.2 \% \\
11.0 \% \\
13.1 \% \\
19.4 \% \\
\end{array}$ \\
\hline $\begin{array}{l}\text { SAM Multiplier } \\
\text { Output } \\
\text { Employment } \\
\text { Value Added } \\
\text { Employee Comp. }\end{array}$ & $\begin{array}{l}+0.22 \\
+0.16 \\
+0.29 \\
+0.13\end{array}$ & & $\begin{array}{l}+0.05 \\
+0.11 \\
+0.46 \\
+0.14\end{array}$ & & $\begin{array}{l}+0.03 \\
+0.04 \\
+0.22 \\
+0.00\end{array}$ & \\
\hline
\end{tabular}

From 2010 to 2015, the sector witnessed badly-needed increases in direct sales, jobs, and employee compensation. Despite a continued reduction in direct value added of 19.2 percent, or \$11.4 million, from 2010 to 2015, the sector's total contribution rose for all measures due to increases in indirect and induced contributions (Table 11). The increases in the sector's total contributions were generally on par with those of the industry for every measure but below those of the industry in terms of value added. This resulted in the sector not substantially growing its 
share of overall industry total contribution over this period. Between 2015 and 2017, the wood furniture sector was the only major FPI sector to experience increases in both direct and total contributions of all measures. The increases may be partially due to actions taken by WV Governor Jim Justice who explicitly named the sector on the campaign trail and in his first State of the State speech in February 2017 as a manufacturing sector his administration would be targeting for growth (Snedegar, 2018). The sector's increases resulted in its direct contributions of output, jobs, value added, and employee compensation to account for 8.4 percent, 15 percent, 6.6 percent, and 16.4 percent of that of the industry overall in 2017 , respectively.

\section{$\underline{\text { Logging }}$}

The logging sector also experienced significant decreases in direct contribution from 2006 to 2010. For every measure of direct contribution other than employee compensation, the percentage losses were greater than that of the industry as a whole. However, these losses were somewhat offset by gains in indirect and induced contributions. In fact, despite losing 926 jobs directly in the logging sector from 2006 to 2010, the sector supported a slightly larger number of jobs within the entirety of the state economy as total contributions increased from 3,173 jobs in 2006 to 3,200 in 2010 (Table 13). This is reflected in the increase of SAM multiplier for logging sector employment from 1.31 to 2.14 , between these years. This was largely due to the increase in the sector's induced contributions of employment, which suggests that the logging sector's demand for inputs was supporting a much larger amount of employment in other sectors of the economy. 
Table 13. The historical economic contribution of the WV logging sector and associated SAM multipliers: 2006, 2010, 2015, 2017. Dollar amounts reported in 2017 dollars.

\begin{tabular}{|l|r|r|r|r|}
\hline \multicolumn{1}{|c|}{ Contribution Type } & \multicolumn{1}{c|}{$\mathbf{2 0 0 6}$} & \multicolumn{1}{c|}{$\mathbf{2 0 1 0}$} & \multicolumn{1}{c|}{$\mathbf{2 0 1 5}$} & \multicolumn{1}{c|}{$\mathbf{2 0 1 7}$} \\
\hline Direct & & & & \\
Output (\$MM) & 248.7 & 143.1 & 145.3 & 354.3 \\
Employment & 2,419 & 1,493 & 1,940 & 1,919 \\
Value Added (\$MM) & 126.9 & 81.1 & 80.7 & 312.2 \\
Employee Comp. (\$MM) & 49.7 & 32.2 & 39.1 & 36.3 \\
\hline Indirect & & & & \\
Output (\$MM) & 50.0 & 40.7 & 35.5 & 19.3 \\
Employment & 647 & 1,161 & 947 & 453 \\
Value Added (\$MM) & 21.7 & 21.2 & 16.7 & 10.8 \\
Employee Comp. (\$MM) & 9.3 & 9.4 & 7.3 & 5.5 \\
\hline Induced & & & & \\
Output (\$MM) & 60.9 & 65.8 & 74.8 & 138.1 \\
Employment & 454 & 548 & 636 & 1,173 \\
Value Added (\$MM) & 34.5 & 39.6 & 44.0 & 82.3 \\
Employee Comp. (\$MM) & 16.0 & 19.8 & 22.8 & 43.3 \\
\hline Total & & & & \\
Output (\$MM) & 358.8 & 249.3 & 255.4 & 511.5 \\
Employment & 3,173 & 3,200 & 3,521 & 3,544 \\
Value Added (\$MM) & 182.7 & 141.7 & 141.2 & 405.2 \\
Employee Comp. (\$MM) & 74.8 & 61.3 & 69.1 & 85.1 \\
\hline SAM Multiplier & & & & \\
Output & 1.44 & 1.74 & 1.76 & 1.44 \\
Employment & 1.31 & 2.14 & 1.81 & 1.85 \\
Value Added & 1.44 & 1.75 & 1.75 & 1.30 \\
Employee Comp. & 1.51 & 1.90 & 1.77 & 2.34 \\
\hline
\end{tabular}


Table 14. Changes in the contribution of the WV logging sector and associated changes in SAM multipliers: 2006 to 2010, 2010 to 2015, 2015 to 2017. Dollar amounts reported in 2017 dollars. Percentages represent changes in contribution levels.

\begin{tabular}{|l|rr|rr|rr|}
\hline \multicolumn{1}{|c|}{ Contribution Type } & \multicolumn{1}{c|}{$\mathbf{1 0 6}$ to '10 } & '10 to '15 & '15 to '17 \\
\hline Direct & & & & & & \\
Output (\$MM) & -105.6 & $-42.5 \%$ & 2.2 & $1.6 \%$ & 209.0 & $143.9 \%$ \\
Employment & -926 & $-38.3 \%$ & 447 & $29.9 \%$ & -21 & $-1.1 \%$ \\
Value Added (\$MM) & -45.8 & $-36.1 \%$ & -0.4 & $-0.5 \%$ & 231.5 & $286.8 \%$ \\
Employee Comp. (\$MM) & -17.5 & $-35.1 \%$ & 6.8 & $21.2 \%$ & -2.8 & $-7.1 \%$ \\
\hline Indirect & & & & & & \\
Output (\$MM) & -9.3 & $-18.6 \%$ & -5.2 & $-12.8 \%$ & -16.2 & $-45.7 \%$ \\
Employment & 514 & $79.5 \%$ & -214 & $-18.4 \%$ & -494 & $-52.2 \%$ \\
Value Added (\$MM) & -0.5 & $-2.1 \%$ & -4.5 & $-21.3 \%$ & -5.9 & $-35.1 \%$ \\
Employee Comp. (\$MM) & 0.1 & $0.9 \%$ & -2.0 & $-21.9 \%$ & -1.8 & $-25.0 \%$ \\
\hline Induced & & & & & & \\
Output (\$MM) & 4.9 & $8.0 \%$ & 9.0 & $13.6 \%$ & 63.3 & $84.7 \%$ \\
Employment & 95 & $20.9 \%$ & 88 & $16.0 \%$ & 537 & $84.5 \%$ \\
Value Added (\$MM) & 5.2 & $15.0 \%$ & 4.3 & $10.9 \%$ & 38.3 & $87.2 \%$ \\
Employee Comp. (\$MM) & 3.8 & $23.9 \%$ & 3.0 & $15.2 \%$ & 20.5 & $89.9 \%$ \\
\hline Total & & & & & & \\
Output (\$MM) & -109.5 & $-30.5 \%$ & 6.0 & $2.4 \%$ & 256.2 & $100.3 \%$ \\
Employment & 27 & $0.9 \%$ & 321 & $10.0 \%$ & 23 & $0.7 \%$ \\
Value Added (\$MM) & -40.9 & $-22.4 \%$ & -0.5 & $-0.4 \%$ & 263.9 & $186.9 \%$ \\
Employee Comp. (\$MM) & -13.5 & $-18.0 \%$ & 7.8 & $12.7 \%$ & 16.0 & $23.1 \%$ \\
\hline SAM Multiplier & & & & & & \\
Output & +0.30 & & +0.01 & & -0.31 & \\
Employment & +0.83 & & -0.33 & & +0.03 & \\
Value Added & +0.31 & +0.00 & & -0.45 & \\
Employee Comp. & +0.40 & -0.13 & & +0.57 & \\
\hline
\end{tabular}

From 2010 to 2015, large decreases in indirect contributions stifled growth in the total contributions of the sector. This suggests the sector have less inter-industry activity in the state, despite a general increase in direct sector activity. These decreases in indirect contributions are illustrated in the decrease in sector SAM multiplier values for employment and employee compensation, and stagnation of those for output and value added. Sector SAM multiplier values were lower than those of the overall industry in 2015 for every measure but output. Although, 
logging sector direct jobs grew substantially from 2010 to 2015 adding 447 logging jobs to arrive at a 2015 total of 1,940, or 19.1 percent of total FPI direct employment. A coinciding increase in direct employee compensation of $\$ 6.8$ million brought the 2015 level to $\$ 39.1$ million or 10 percent of that of the industry. From 2015 to 2017, the logging sector experienced even larger increases in direct contributions of output and value added, despite decreases in employment and employee compensation. The largest growth took place in the sector's direct contribution of value added which rose by $\$ 231.5$ million or nearly 3 times its 2015 value of $\$ 81.1$ million.

\section{Forestry}

Despite decreases of direct and total contributions of all measures between 2006 and 2010, the forest sector fared much better than the industry overall. The particularly muted decrease in employment resulted in the sector accounting for 5.5 percent of the industry's overall direct employment in 2010, compared to 3.7 percent in 2006. 
Table 15. The historical economic contribution of the WV forestry sector and associated SAM multipliers: 2006, 2010, 2015, 2017. Dollar amounts reported in 2017 dollars.

\begin{tabular}{|l|r|r|r|r|}
\hline \multicolumn{1}{|c|}{ Contribution Type } & \multicolumn{1}{c|}{$\mathbf{2 0 0 6}$} & \multicolumn{1}{c|}{$\mathbf{2 0 1 0}$} & \multicolumn{1}{c|}{$\mathbf{2 0 1 5}$} & \multicolumn{1}{c|}{$\mathbf{2 0 1 7}$} \\
\hline Direct & & & & \\
Output (\$MM) & 30.2 & 25.2 & 24.8 & 26.4 \\
Employment & 551 & 534 & 497 & 792 \\
Value Added (\$MM) & 19.3 & 17.2 & 17.5 & 22.7 \\
Employee Comp. (\$MM) & 8.3 & 6.6 & 4.5 & 17.6 \\
\hline Indirect & 2.9 & & & \\
Output (\$MM) & 29 & 32 & 2.5 & 1.8 \\
Employment & 1.4 & 1.5 & 1.2 & 19 \\
Value Added (\$MM) & 0.5 & 0.7 & 0.6 & 1.0 \\
Employee Comp. (\$MM) & & & & \\
\hline Induced & 8.8 & 9.3 & 9.7 & 20.9 \\
Output (\$MM) & 64 & 77 & 83 & 176 \\
Employment & 4.9 & 5.6 & 5.7 & 12.3 \\
Value Added (\$MM) & 2.2 & 2.8 & 3.0 & 6.4 \\
Employee Comp. (\$MM) & & & & \\
Total & 41.4 & 36.6 & 36.7 & 48.7 \\
Output (\$MM) & 636 & 628 & 596 & 977 \\
Employment & 25.3 & 23.9 & 24.2 & 35.8 \\
Value Added (\$MM) & 10.9 & 9.9 & 8.0 & 24.4 \\
Employee Comp. (\$MM) & & & & \\
\hline SAM Multiplier & 1.37 & 1.45 & 1.48 & 1.85 \\
Output & 1.15 & 1.18 & 1.20 & 1.23 \\
Employment & 1.32 & 1.39 & 1.38 & 1.57 \\
Value Added & 1.31 & 1.51 & 1.78 & 1.39 \\
\hline Employee Comp. & & & \\
\hline
\end{tabular}


Table 16. Changes in the contribution of the WV forestry sector and associated changes in SAM multipliers: 2006 to 2010, 2010 to 2015, 2015 to 2017. Dollar amounts reported in 2017 dollars. Percentages represent changes in contribution levels.

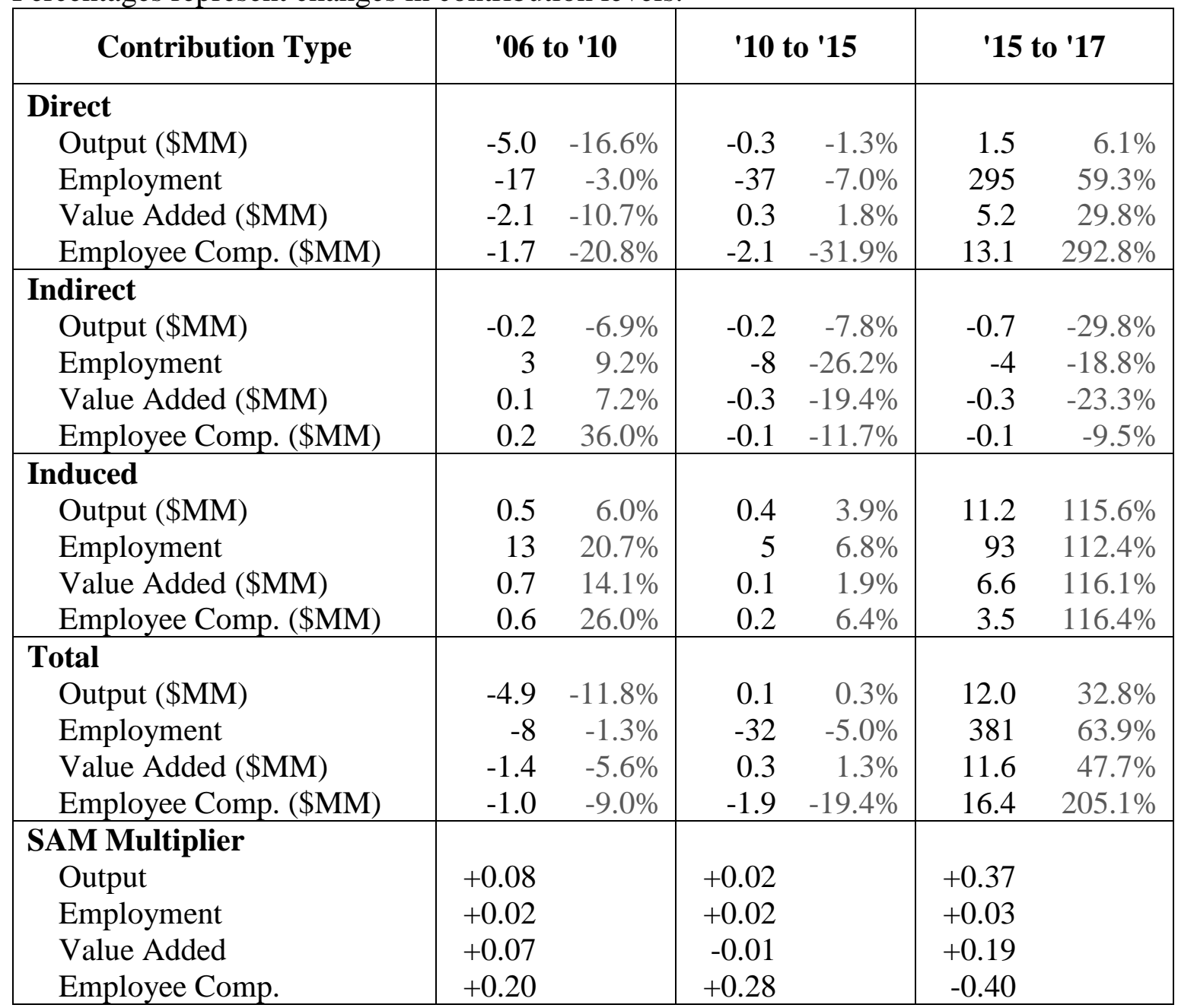

Between 2010 and 2015, the sector experienced the largest percentage decrease of any measure over this time in the sector's direct contribution of employee compensation, which fell by 31.9 percent (Table 16). Employment, by comparison, fell 7 percent from 2010 levels. Decreases in sector direct output, many of which were also included in the decrease in indirect contributions of output, were offset by increases in induced contributions which resulted in a slight 0.3 percent increase in the sector's total contribution of output to the broader economy. Much like the 
logging sector, the forestry sector also experienced immense increases in contribution between 2015 to 2017. Unlike the logging sector, however, the increases were experienced in employment and employee compensation by both direct and total contributions. Sector direct employee compensation increased by $\$ 13.1$ million, or nearly three times its 2015 level. This increase in employee compensation coincided with a relatively small, although still large, 59.3 percent increase in direct employment for the sector.

\section{$\underline{\text { Pulp, Paper, and Paperboard }}$}

The pulp, paper, and paperboard sector was the only industry sector in which total contributions of all measures increased between 2006 and 2010 and the only sector to experience a gain in direct contribution of any measure. Despite losses in direct contributions of output, jobs, and employee compensation, direct value added increased from 2006 to 2010 (Table 17). This may point to an excess of raw materials that the sector was able to capitalize on, despite overall lower levels of sales. Also, large increases in the sector's indirect and induced contributions over this period increased the sector's total contributions to the state economy. These gains are, again, illustrated in the dramatic increases in the sector's associated SAM multiplier values, particularly in employment, which had the largest multiplier increase of any measure of any sector over these years. Dahal et al. (2015) reported SAM multipliers of the paper and allied products sectors of 13 US Southern states for 2009 but because of differences in sector construction, the reported multiplier values are not directly comparable to those found for West Virginia in 2010. However, it can be noted that the study found employment multipliers in the paper allied products sectors of the South in 2009 to be especially large as compared to those of output and value added. 
Table 17. The historical economic contribution of the WV pulp, paper, and paperboard sector and associated SAM multipliers: 2006, 2010, 2015, 2017. Dollar amounts reported in 2017 dollars.

\begin{tabular}{|l|r|r|r|r|}
\hline \multicolumn{1}{|c|}{ Contribution Type } & \multicolumn{1}{c|}{$\mathbf{2 0 0 6}$} & \multicolumn{1}{c|}{$\mathbf{2 0 1 0}$} & \multicolumn{1}{c|}{$\mathbf{2 0 1 5}$} & \multicolumn{1}{c|}{$\mathbf{2 0 1 7}$} \\
\hline Direct & & & & \\
Output (\$MM) & 229.0 & 209.5 & 193.7 & 150.7 \\
Employment & 337 & 300 & 260 & 232 \\
Value Added (\$MM) & 33.3 & 36.1 & 30.2 & 21.4 \\
Employee Comp. (\$MM) & 24.8 & 22.7 & 19.5 & 15.8 \\
\hline Indirect & & & & \\
Output (\$MM) & 66.4 & 86.4 & 91.2 & 79.5 \\
Employment & 332 & 514 & 527 & 410 \\
Value Added (\$MM) & 25.9 & 39.0 & 40.1 & 40.5 \\
Employee Comp. (\$MM) & 13.8 & 20.8 & 21.6 & 19.1 \\
\hline Induced & & & & \\
Output (\$MM) & 20.3 & 37.0 & 44.2 & 39.2 \\
Employment & 152 & 310 & 381 & 339 \\
Value Added (\$MM) & 11.6 & 22.4 & 26.3 & 23.7 \\
Employee Comp. (\$MM) & 5.4 & 11.4 & 13.9 & 12.8 \\
\hline Total & & & & \\
Output (\$MM) & 314.8 & 332.7 & 328.3 & 269.2 \\
Employment & 753 & 1,124 & 1,167 & 980 \\
Value Added (\$MM) & 66.0 & 97.4 & 96.5 & 85.6 \\
Employee Comp. (\$MM) & 40.4 & 54.9 & 55.0 & 47.7 \\
\hline SAM Multiplier & & & & \\
Output & 1.37 & 1.59 & 1.70 & 1.79 \\
Employment & 2.23 & 3.74 & 4.49 & 4.23 \\
Value Added & 1.99 & 2.70 & 3.19 & 3.99 \\
Employee Comp. & 1.63 & 2.42 & 2.82 & 3.01 \\
\hline
\end{tabular}


Table 18. Changes in the contribution of the WV pulp, paper, and paperboard sector and associated changes in SAM multipliers: 2006 to 2010, 2010 to 2015, 2015 to 2017. Dollar amounts reported in 2017 dollars. Percentages represent changes in contribution levels.

\begin{tabular}{|c|c|c|c|c|c|c|}
\hline Contribution Type & \multicolumn{2}{|c|}{ '06 to '10 } & \multicolumn{2}{|c|}{ '10 to ' 15} & \multicolumn{2}{|c|}{ '15 to ' 17} \\
\hline $\begin{array}{l}\text { Output }(\$ M M) \\
\text { Employment } \\
\text { Value Added }(\$ M M) \\
\text { Employee Comp. }(\$ M M)\end{array}$ & $\begin{array}{r}-19.5 \\
-37 \\
2.8 \\
-2.1\end{array}$ & $\begin{array}{r}-8.5 \% \\
-11.0 \% \\
8.5 \% \\
-8.5 \%\end{array}$ & $\begin{array}{r}-15.8 \\
-40 \\
-5.8 \\
-3.2\end{array}$ & $\begin{array}{r}-7.5 \% \\
-13.4 \% \\
-16.2 \% \\
-14.1 \%\end{array}$ & $\begin{array}{r}-42.9 \\
-29 \\
-8.8 \\
-3.7 \\
\end{array}$ & $\begin{array}{l}-22.2 \% \\
-11.0 \% \\
-29.1 \% \\
-18.9 \%\end{array}$ \\
\hline $\begin{array}{l}\text { Indirect } \\
\text { Output (\$MM) } \\
\text { Employment } \\
\text { Value Added (\$MM) } \\
\text { Employee Comp. (\$MM) }\end{array}$ & $\begin{array}{r}20.0 \\
182 \\
13.0 \\
7.1 \\
\end{array}$ & $\begin{array}{l}30.1 \% \\
55.0 \% \\
50.3 \% \\
51.2 \% \\
\end{array}$ & $\begin{array}{r}4.9 \\
13 \\
1.1 \\
0.8\end{array}$ & $\begin{array}{l}5.6 \% \\
2.5 \% \\
2.8 \% \\
3.9 \% \\
\end{array}$ & $\begin{array}{r}-11.8 \\
-117 \\
0.4 \\
-2.6 \\
\end{array}$ & $\begin{array}{r}-12.9 \% \\
-22.2 \% \\
1.0 \% \\
-11.9 \% \\
\end{array}$ \\
\hline $\begin{array}{l}\text { Induced } \\
\text { Output (\$MM) } \\
\text { Employment } \\
\text { Value Added }(\$ M M) \\
\text { Employee Comp. (\$MM) }\end{array}$ & $\begin{array}{r}16.6 \\
157 \\
10.9 \\
6.0 \\
\end{array}$ & $\begin{array}{r}82.0 \% \\
103.3 \% \\
94.0 \% \\
109.4 \% \\
\end{array}$ & $\begin{array}{r}7.3 \\
71 \\
3.9 \\
2.5 \\
\end{array}$ & $\begin{array}{l}19.6 \% \\
23.0 \% \\
17.2 \% \\
22.2 \% \\
\end{array}$ & $\begin{array}{r}-5.0 \\
-42 \\
-2.6 \\
-1.1 \\
\end{array}$ & $\begin{array}{r}-11.4 \% \\
-11.1 \% \\
-9.8 \% \\
-8.1 \% \\
\end{array}$ \\
\hline $\begin{array}{l}\text { Total } \\
\text { Output (\$MM) } \\
\text { Employment } \\
\text { Value Added }(\$ M M) \\
\text { Employee Comp. }(\$ M M))\end{array}$ & $\begin{array}{r}17.9 \\
371 \\
31.4 \\
14.5 \\
\end{array}$ & $\begin{array}{r}5.7 \% \\
49.2 \% \\
47.6 \% \\
35.8 \% \\
\end{array}$ & $\begin{array}{r}-4.4 \\
43 \\
-1.0 \\
0.0 \\
\end{array}$ & $\begin{array}{r}-1.3 \% \\
3.8 \% \\
-1.0 \% \\
0.1 \% \\
\end{array}$ & $\begin{array}{r}-59.2 \\
-187 \\
-10.9 \\
-7.3 \\
\end{array}$ & $\begin{array}{l}-18.0 \% \\
-16.0 \% \\
-11.3 \% \\
-13.3 \% \\
\end{array}$ \\
\hline $\begin{array}{l}\text { SAM Multiplier } \\
\text { Output } \\
\text { Employment } \\
\text { Value Added } \\
\text { Employee Comp. }\end{array}$ & $\begin{array}{l}+0.21 \\
+1.51 \\
+0.72 \\
+0.79\end{array}$ & & $\begin{array}{l}+0.11 \\
+0.74 \\
+0.49 \\
+0.40\end{array}$ & & $\begin{array}{r}+0.09 \\
-0.26 \\
+0.80 \\
+0.19\end{array}$ & \\
\hline
\end{tabular}

Between 2010 and 2015 the sector saw continued decreases in direct contributions of output, employment, and employee compensation. However, unlike the changes between 2006 and 2010, there was also a significant decrease in the sector's direct value added. Continued increases of induced contributions were not enough to compensate for these losses of direct contributions, resulting in a decrease in total contributions of output and value added. In 2015, although the sector ranked last in terms of direct employment, it ranked $5^{\text {th }}$ (out of 7) in terms of 
direct employee compensation and direct value added. Between 2015 and 2017, the most substantial percentage decreases in direct contributions of any FPI sector took place in the pulp, paper, and paperboard sector. A decrease of 29 employees working in the sector led to it being ranked last in terms of direct employment for 2017.

\section{Secondary Paperboard and Other Paper Products}

Similar to the pulp, paper, and paperboard sector, the secondary paperboard and other paper products sector also experienced decreases in direct contributions of output, employment, and employee compensation from 2006 to 2010 (Table 20). However, decreases were more severe and were also experienced in terms of direct value added. Unlike the pulp, paper, and paperboard sector, increases of the sector's indirect and induced contributions were relatively low. This resulted in decreased total contributions from the sector by all measures from 2006 to 2010 . 
Table 19. The historical economic contribution of the WV secondary paperboard and other paper products sector and associated SAM multipliers: 2006, 2010, 2015, 2017. Dollar amounts reported in 2017 dollars.

\begin{tabular}{|c|c|c|c|c|}
\hline Contribution Type & 2006 & 2010 & 2015 & 2017 \\
\hline $\begin{array}{l}\text { Direct } \\
\text { Output (\$MM) } \\
\text { Employment } \\
\text { Value Added (\$MM) } \\
\text { Employee Comp. }(\$ M M)\end{array}$ & $\begin{array}{r}130.2 \\
443 \\
28.4 \\
25.7\end{array}$ & $\begin{array}{r}92.7 \\
339 \\
20.7 \\
18.4\end{array}$ & $\begin{array}{r}134.8 \\
315 \\
26.8 \\
18.9\end{array}$ & $\begin{array}{r}109.3 \\
281 \\
20.5 \\
16.0\end{array}$ \\
\hline $\begin{array}{l}\text { Indirect } \\
\text { Output (\$MM) } \\
\text { Employment } \\
\text { Value Added (\$MM) } \\
\text { Employee Comp. }(\$ M M) \\
\end{array}$ & $\begin{array}{r}14.9 \\
77 \\
6.7 \\
3.8 \\
\end{array}$ & $\begin{array}{r}15.7 \\
91 \\
8.1 \\
4.5 \\
\end{array}$ & $\begin{array}{r}26.1 \\
155 \\
13.0 \\
7.3 \\
\end{array}$ & $\begin{array}{r}23.4 \\
139 \\
12.5 \\
6.8 \\
\end{array}$ \\
\hline $\begin{array}{l}\text { Induced } \\
\text { Output (\$MM) } \\
\text { Employment } \\
\text { Value Added (\$MM) } \\
\text { Employee Comp. }(\$ M M) \\
\end{array}$ & $\begin{array}{r}14.4 \\
105 \\
8.0 \\
3.7 \\
\end{array}$ & $\begin{array}{r}16.6 \\
137 \\
10.0 \\
5.0\end{array}$ & $\begin{array}{r}24.9 \\
213 \\
14.7 \\
7.7 \\
\end{array}$ & $\begin{array}{r}22.1 \\
190 \\
13.3 \\
7.1 \\
\end{array}$ \\
\hline $\begin{array}{l}\text { Total } \\
\text { Output (\$MM) } \\
\text { Employment } \\
\text { Value Added (\$MM) } \\
\text { Employee Comp. (\$MM) }\end{array}$ & $\begin{array}{r}159.3 \\
625 \\
43.2 \\
33.1 \\
\end{array}$ & $\begin{array}{r}125.0 \\
568 \\
38.8 \\
27.9 \\
\end{array}$ & $\begin{array}{r}185.7 \\
683 \\
54.4 \\
33.9 \\
\end{array}$ & $\begin{array}{r}154.8 \\
609 \\
46.3 \\
30.0 \\
\end{array}$ \\
\hline $\begin{array}{l}\text { SAM Multiplier } \\
\text { Output } \\
\text { Employment } \\
\text { Value Added } \\
\text { Employee Comp. } \\
\end{array}$ & $\begin{array}{l}1.22 \\
1.41 \\
1.52 \\
1.29 \\
\end{array}$ & $\begin{array}{l}1.35 \\
1.67 \\
1.87 \\
1.51 \\
\end{array}$ & $\begin{array}{l}1.38 \\
2.17 \\
2.03 \\
1.79 \\
\end{array}$ & $\begin{array}{l}1.42 \\
2.17 \\
2.26 \\
1.87\end{array}$ \\
\hline
\end{tabular}


Table 20. Changes in the contribution of the WV secondary paperboard and other paper products sector and associated changes in SAM multipliers: 2006 to 2010, 2010 to 2015, 2015 to 2017. Dollar amounts reported in 2017 dollars. Percentages represent changes in contribution levels.

\begin{tabular}{|l|rr|rr|rr|}
\hline \multicolumn{1}{|c|}{ Contribution Type } & '06 to '10 & \multicolumn{2}{|c|}{ '10 to '15 } & '15 to '17 \\
\hline Direct & & & & & & \\
$\quad$ Output (\$MM) & -37.5 & $-28.8 \%$ & 42.1 & $45.4 \%$ & -25.5 & $-18.9 \%$ \\
Employment & -103 & $-23.3 \%$ & -24 & $-7.1 \%$ & -35 & $-11.0 \%$ \\
$\quad$ Value Added (\$MM) & -7.7 & $-27.1 \%$ & 6.1 & $29.3 \%$ & -6.3 & $-23.6 \%$ \\
$\quad$ Employee Comp. (\$MM) & -7.3 & $-28.3 \%$ & 0.4 & $2.4 \%$ & -2.8 & $-15.1 \%$ \\
\hline Indirect & & & & & & \\
$\quad$ Output (\$MM) & 0.8 & $5.4 \%$ & 10.4 & $66.3 \%$ & -2.7 & $-10.3 \%$ \\
Employment & 14 & $18.0 \%$ & 64 & $70.1 \%$ & -16 & $-10.5 \%$ \\
Value Added (\$MM) & 1.4 & $20.5 \%$ & 4.9 & $60.0 \%$ & -0.5 & $-3.5 \%$ \\
Employee Comp. (\$MM) & 0.7 & $18.6 \%$ & 2.8 & $63.8 \%$ & -0.5 & $-6.7 \%$ \\
\hline Induced & & & & & & \\
Output (\$MM) & 2.2 & $15.7 \%$ & 8.3 & $49.9 \%$ & -2.8 & $-11.3 \%$ \\
Employment & 32 & $30.7 \%$ & 75 & $54.9 \%$ & -23 & $-10.9 \%$ \\
Value Added (\$MM) & 1.9 & $24.1 \%$ & 4.7 & $47.2 \%$ & -1.4 & $-9.6 \%$ \\
Employee Comp. (\$MM) & 1.3 & $35.8 \%$ & 2.7 & $54.5 \%$ & -0.6 & $-7.5 \%$ \\
\hline Total & & & & & & \\
Output (\$MM) & -34.4 & $-21.6 \%$ & 60.8 & $48.6 \%$ & -31.0 & $-16.7 \%$ \\
Employment & -57 & $-9.1 \%$ & 115 & $20.3 \%$ & -74 & $-10.9 \%$ \\
Value Added (\$MM) & -4.4 & $-10.2 \%$ & 15.6 & $40.3 \%$ & -8.2 & $-15.0 \%$ \\
Employee Comp. (\$MM) & -5.3 & $-15.9 \%$ & 6.0 & $21.5 \%$ & -3.9 & $-11.5 \%$ \\
\hline SAM Multiplier & & & & & & \\
Output & +0.12 & & +0.03 & & +0.04 & \\
Employment & +0.26 & & +0.49 & & +0.00 & \\
Value Added & +0.35 & & +0.16 & & +0.23 & \\
Employee Comp. & +0.22 & +0.28 & & +0.07 & \\
\hline
\end{tabular}

Between 2010 and 2015, the largest percentage gain of any direct contribution took place in the sector's direct output which rose by a substantial 45.4 percent from 2010 to 2015. Despite the sector directly employing 24 less employees between these years, employee compensation rose slightly which may be reflective of an increasingly automated sector requiring a smaller but more highly-skilled workforce. Despite the large increases in direct sector output and value added, some of the largest percentage decreases in contribution were found in the sector between 2015 
and 2017. Like the pulp, paper, and paperboard sector, the sector saw double-digit percentage decreases of all measures of direct and total contributions.

\subsection{FPI Contributions to the Regions of West Virginia for 2006 and 2017}

\subsubsection{Region 1-Ohio River Region}

\section{The Ohio River Region FPI}

Region 1, the Ohio River region, is a group of 12 counties along the western West Virginia border with Ohio. The region has historically benefited from its proximity to the Ohio River as it served as a means of transporting resources such as timber and coal from the surrounding area and as a foundation for a historically large chemicals manufacturing industry. With the increase in Marcellus Shale natural gas exploration in the greater Mid-Ohio Valley since the mid-2000s, many of the region's economic development efforts have been concentrated in attracting downstream natural gas activity. The natural gas industry's competition for the region's economic development resources has likely not benefitted FPI performance in the region over this time. The economic contributions of the FPI to the region in 2006 and 2017 are shown in Table 21. In 2006, the direct contributions of the industry in the region were the lowest of the five regions analyzed for this year by every measure. Location quotients for the industry were 0.40 for employment and 0.35 for value added, illustrating that the region's economy was much less concentrated in the FPI than the state economy in 2006. Direct contributions of taxes in the region were \$7.2 million in state and local taxes and \$18.3 million in federal taxes for the year. Between 2006 and 2017, the region's FPI direct contributions had decreased by 19.8 percent in terms of output, 41.4 percent in terms of employment, 32.7 percent in terms of value added, and 36.1 percent in terms of employee compensation. While the loss in direct industry employment 
was the largest percentage decrease of any region analyzed, it was the second least severe loss in absolute terms, due to the small size of the industry in the region. By 2017, the region's FPI made up just 11.5 percent, 9.9 percent, 7.9 percent, and 10.3 percent of the industry's statewide direct contributions of output, employment, value added, and employee compensation, respectively. As was the case in 2006, the industry's direct contributions of all measures in 2017 were the smallest of any region analyzed. Quite large increases in indirect and induced contributions resulted in much less severe decreases in industry total contributions of output, employment, and employee compensation, and a marginal increase of value added, or the industry's total contribution to gross regional product. This growth in non-direct contributions by the industry are reflected in increases in the industry's associated multiplier values. Location quotients for the industry decreased from 2006 to 2017 to 0.36 for direct jobs and 0.28 for direct value added. The industry direct contributions of taxes for 2017 also decreased from 2006 levels to $\$ 2.9$ million in state and local taxes and $\$ 8.5$ million in federal taxes.

Table 21. Contributions of the Region 1 forest products industry and associated SAM multipliers for years 2006 and 2017. Dollar amounts reported in 2017 dollars.

\begin{tabular}{|l|r|r|r|r|r|r|r|r|}
\hline \multirow{2}{*}{ Contribution Type } & \multicolumn{2}{|c|}{ Output (\$MM) } & \multicolumn{2}{c|}{ Employment } & \multicolumn{2}{c|}{$\begin{array}{c}\text { Value Added } \\
\text { (\$MM) }\end{array}$} & \multicolumn{2}{c|}{$\begin{array}{c}\text { Employee } \\
\text { Comp. (\$MM) }\end{array}$} \\
\hline \multirow{4}{*}{ Direct } & \multicolumn{1}{|c|}{2006} & \multicolumn{1}{|c|}{2017} & \multicolumn{1}{|c|}{2006} & \multicolumn{1}{|c|}{2017} & 2006 & \multicolumn{1}{|c|}{2017} & \multicolumn{1}{c|}{2006} & 2017 \\
\cline { 2 - 9 } Indirect & 318.1 & 255.2 & 1,714 & 1,005 & 88.1 & 59.3 & 65.0 & 41.5 \\
Induced & 47.3 & 66.4 & 333 & 462 & 20.4 & 36.0 & 10.5 & 17.9 \\
Total & 23.8 & 45.5 & 146 & 376 & 12.7 & 26.1 & 4.6 & 13.2 \\
\hline SAM Multiplier & 378.1 & 360.4 & 2,096 & 1,776 & 117.3 & 117.6 & 78.6 & 72.0 \\
\hline
\end{tabular}

\section{The Ohio River Region FPI Major Sectors}

The contributions of the region's individual FPI major sectors for the years 2006 and 2017 are presented in Table 22 and a comparison of the separate sectors' share of the region's overall industry direct output for 2006 and 2017 are shown in Figure 2. In 2006, the region's FPI was 
largely concentrated in the secondary solid wood products and secondary paperboard and other paper products sectors as over 50 percent of all measures of the regional industry's direct contributions were derived from these two sectors. The secondary solid wood products sector was the largest source of direct contributions for the regional industry, accounting for 31.2 percent, 35.9 percent, 35.3 percent, and 37.7 percent of industry direct output, employment, value added, and employee compensation, respectively. In 2006, over 70 percent of the state's secondary paperboard and other paper products sector direct contributions occurred in the region. The concentration of the industry in secondary paperboard and other paper products, rather than the pulp, paper and paperboard sector, is likely due to the lack of large pulp, paper, and paperboard mills which have been concentrated farther west in Ohio. The region's FPI was also somewhat more highly concentrated in the wood furniture sector than the statewide industry while being much less concentrated in the primary solid wood products and logging sectors.

Figure 2. Forest products major sector share of overall FPI direct contributions of output for Region 1: 2006 vs 2017.

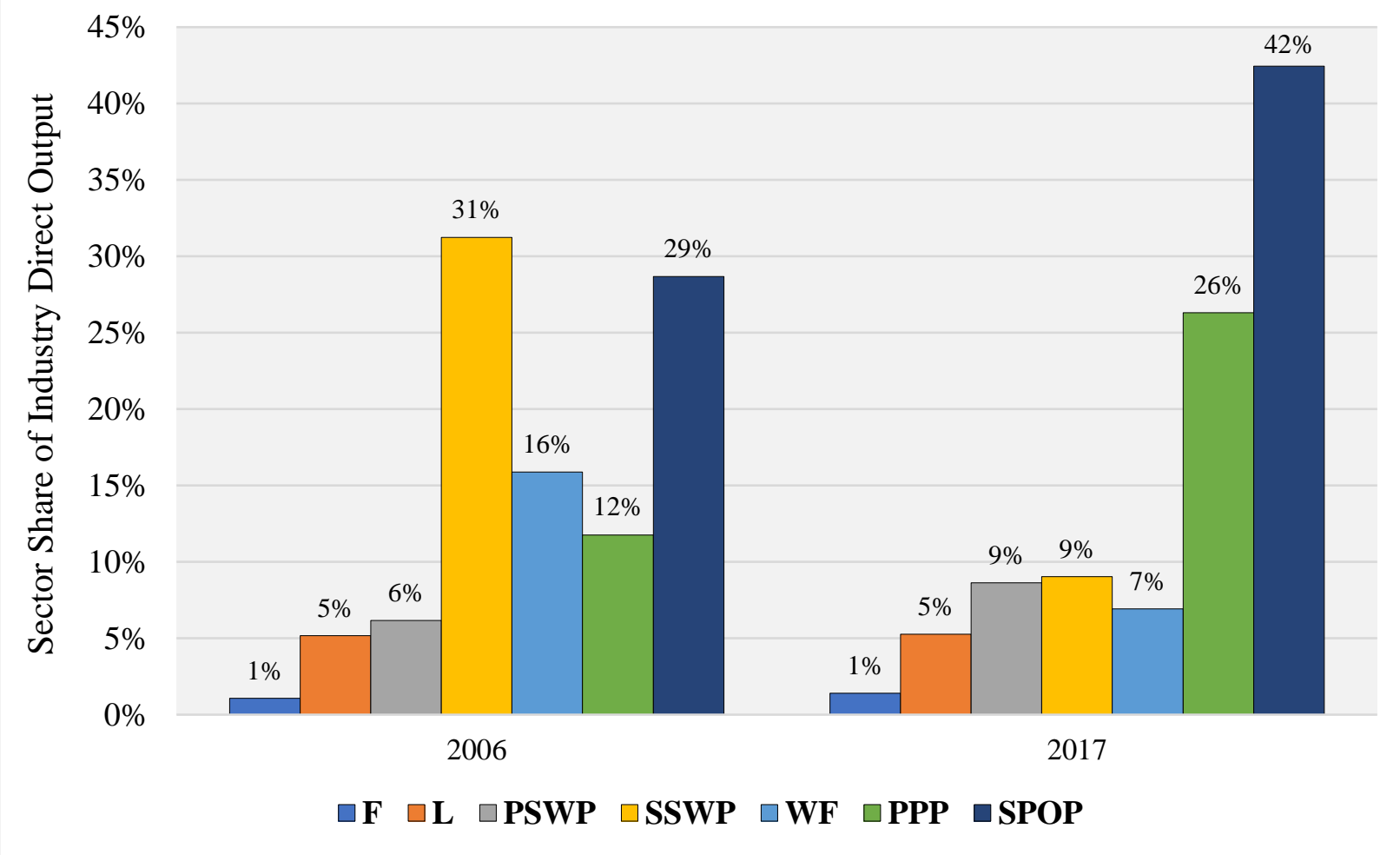


Between 2006 and 2017, the largest percentage and absolute decreases in direct and total contributions of the region's FPI took place in the secondary solid wood products sector. By 2017, direct and total contributions of the sector fell by more than 70 percent from 2006 levels which were far more severe than those of the sector statewide. The wood furniture sector also saw immense decreases in the region over these years, with a 65 percent decrease in direct output, a 61.3 percent decrease in direct employment, a 74.4 percent decrease in direct value added, and a 49 percent decrease in employee compensation. In 2006, 18.5 percent of the state's direct output of the wood furniture sector took place within the Ohio River region. By 2017, that had decreased to 10.7 percent. These large decreases in two of the sectors the region was most concentrated in led to the region relying heavily on its pulp and paper related sectors. Over this period, the pulp, paper, and paperboard sector of the region grew in both direct and total contributions of every measure. Pulp, paper, and paperboard direct value added and employee compensation both doubled over this period, while the sector's total contributions of these measures more than tripled. The increases in direct contributions resulted in the sector becoming the industry's second highest contributor of direct output and value added in the region, making up 26.3 percent and 17.1 percent of the industry total, respectively. The region's secondary paperboard and other paper products sector also faired relatively well over this period. Despite decreases from 2006 levels of direct contributions employment and employee compensation, in 2017, the secondary paperboard and other paper products sector was the regional industry's largest source of direct and total contributions of all measures. By 2017, the sector's direct contributions of output, jobs, value added, and employee compensation accounted for 42.4 
percent, 27.7 percent, 34.3 percent, and 38.3 percent of the overall industry's direct contributions in the region. These contributions accounted for over 99 percent of the statewide secondary paperboard and other paper products sector's direct contributions of all measures in 2017. The regional industry's reliance on these sectors are likely due to the proximity of large pulp and paper mills that are located farther West in Ohio. The changes in the region show an industry that, despite massive decreases in two of its largest sectors, was able to avoid major losses in its secondary paperboard and other paper products sector and grow a related pulp, paper, and paperboard sector. Only one other region in the state, the Southern region, was able to grow its pulp, paper, and paperboard sector over this period. While the primary solid wood products and forestry sectors both fared better in the region than the industry overall, they still accounted for a small amount of the regional industry's direct contributions. 
Table 22. Contributions of the Region 1 FPI major sectors and associated SAM multipliers for the year 2017. Dollar amounts reported in 2017 dollars.

\begin{tabular}{|c|c|c|c|c|c|c|c|c|c|c|c|c|c|c|}
\hline \multirow{2}{*}{ Contribution Type } & \multicolumn{2}{|c|}{$\mathbf{F}$} & \multicolumn{2}{|c|}{$\mathbf{L}$} & \multicolumn{2}{|c|}{ PSWP } & \multicolumn{2}{|c|}{ SSWP } & \multicolumn{2}{|c|}{ WF } & \multicolumn{2}{|c|}{ PPP } & \multicolumn{2}{|c|}{ SPOP } \\
\hline & 2006 & 2017 & 2006 & 2017 & 2006 & 2017 & 2006 & 2017 & 2006 & 2017 & 2006 & 2017 & 2006 & 2017 \\
\hline Direct & & & & & & & & & & & & & & \\
\hline Output (\$MM) & 3.4 & 3.6 & 16.5 & 13.5 & 19.6 & 22.0 & 99.4 & 23.0 & 50.5 & 17.7 & 37.4 & 67.1 & 91.2 & 108.3 \\
\hline Employment & 70 & 114 & 179 & 164 & 94 & 81 & 616 & 121 & 382 & 148 & 60 & 98 & 313 & 278 \\
\hline Value Added (\$MM) & 1.9 & 3.2 & 7.3 & 9.8 & 3.6 & 4.1 & 31.1 & 6.4 & 20.7 & 5.3 & 3.4 & 10.1 & 20.1 & 20.3 \\
\hline Employee Comp. (\$MM) & 0.5 & 2.6 & 2.0 & 0.7 & 2.5 & 2.7 & 24.5 & 4.6 & 14.9 & 7.6 & 2.4 & 7.4 & 18.2 & 15.9 \\
\hline Indirect & & & & & & & & & & & & & & \\
\hline Output (\$MM) & 0.3 & 0.1 & 3.2 & 1.4 & 8.0 & 10.1 & 16.9 & 6.5 & 5.6 & 3.9 & 7.8 & 24.8 & 7.9 & 20.7 \\
\hline Employment & 5 & 1 & 67 & 56 & 75 & 89 & 106 & 44 & 36 & 27 & 41 & 146 & 39 & 124 \\
\hline Value Added (\$MM) & 0.2 & 0.1 & 1.2 & 0.7 & 3.5 & 6.0 & 7.2 & 3.5 & 2.6 & 2.1 & 3.0 & 13.0 & 3.7 & 11.3 \\
\hline Employee Comp. (\$MM) & 0.05 & 0.03 & 0.4 & 0.4 & 1.4 & 2.2 & 4.1 & 1.8 & 1.4 & 1.2 & 1.5 & 6.4 & 2.0 & 6.2 \\
\hline Induced & & & & & & & & & & & & & & \\
\hline Output (\$MM) & 0.5 & 2.3 & 2.2 & 4.4 & 1.6 & 4.8 & 8.4 & 4.9 & 5.1 & 5.7 & 1.3 & 10.2 & 5.9 & 15.0 \\
\hline Employment & 3 & 19 & 13 & 37 & 10 & 40 & 51 & 40 & 31 & 47 & 8 & 84 & 36 & 124 \\
\hline Value Added (\$MM) & 0.3 & 1.3 & 1.2 & 2.5 & 0.8 & 2.7 & 4.5 & 2.8 & 2.7 & 3.3 & 0.7 & 5.9 & 3.1 & 8.6 \\
\hline Employee Comp. (\$MM) & 0.1 & 0.7 & 0.4 & 1.3 & 0.3 & 1.4 & 1.6 & 1.4 & 1.0 & 1.7 & 0.2 & 3.0 & 1.1 & 4.4 \\
\hline Total & & & & & & & & & & & & & & \\
\hline Output (\$MM) & 4.2 & 6.0 & 21.8 & 19.2 & 28.6 & 36.5 & 123.7 & 34.3 & 61.3 & 27.3 & 46.5 & 102.1 & 104.9 & 144.0 \\
\hline Employment & 60 & 134 & 259 & 257 & 176 & 208 & 767 & 204 & 450 & 222 & 109 & 329 & 388 & 526 \\
\hline Value Added (\$MM) & 2.1 & 4.6 & 9.7 & 13.1 & 7.8 & 12.8 & 42.4 & 12.6 & 26.0 & 10.7 & 7.1 & 29.0 & 26.9 & 40.2 \\
\hline Employee Comp. (\$MM) & 0.6 & 3.3 & 2.9 & 2.4 & 4.1 & 6.2 & 30.0 & 7.8 & 17.3 & 10.4 & 4.2 & 16.7 & 21.3 & 26.4 \\
\hline SAM Multiplier & & & & & & & & & & & & & & \\
\hline Output (\$MM) & 1.23 & 1.67 & 1.33 & 1.43 & 1.46 & 1.66 & 1.24 & 1.49 & 1.21 & 1.54 & 1.24 & 1.52 & 1.15 & 1.33 \\
\hline Employment & 0.86 & 1.17 & 1.45 & 1.56 & 1.87 & 2.56 & 1.25 & 1.69 & 1.18 & 1.50 & 1.80 & 3.35 & 1.24 & 1.89 \\
\hline Value Added (\$MM) & 1.13 & 1.44 & 1.32 & 1.33 & 2.18 & 3.11 & 1.37 & 1.97 & 1.26 & 2.01 & 2.10 & 2.87 & 1.34 & 1.98 \\
\hline Employee Comp. (\$MM) & 1.20 & 1.27 & 1.42 & 3.25 & 1.67 & 2.34 & 1.22 & 1.70 & 1.16 & 1.37 & 1.73 & 2.26 & 1.17 & 1.66 \\
\hline
\end{tabular}




\subsubsection{Region 2 - North Central Region}

\section{The North Central Region FPI}

The North Central region consists of 13 counties situated in central West Virginia with just one county, Monongalia, sharing a border with another state, Pennsylvania. This region has relatively good transportation infrastructure when compared to the rest of the state with major interstates meeting in Monongalia county and US Highway 50 crossing four of the region's counties. Three state universities are also located in this region, which have historically provided the region with added economic activity and higher education outcomes and a source of high-skilled labor for the region's FPI. Like the Ohio River region, the North Central region has also been heavily impacted by Marcellus Shale natural gas exploration, particularly those counties west of Interstate 79, closer to Ohio. As with the Ohio River region, this has likely not benefitted the FPI in the region as the emerging natural gas industry has competed for labor, economic development, and infrastructure resources. In 2006, the FPI in this region directly contributed $\$ 535$ million in output, 2,221 jobs, $\$ 147.3$ million in value added and $\$ 100.8$ million in employee compensation (Table 23) which accounted for 19.1 percent, 14.8 percent, 16.4 percent, and 16.2 percent of that of the statewide industry, respectively. Location quotients of 0.52 for direct employment and 0.58 for direct value added show that the region's economy was much less specialized in the FPI than the state economy in 2006. Direct industry contributions of taxes for the year were \$5.6 million in state and local taxes and \$20.9 million in federal taxes. From 2006 to 2017, the FPI in the North Central region experienced decrease in both direct and total economic contributions of all measures which were found to be more severe than those of the industry statewide. The percentage decreases in direct industry output and employee compensation, which fell by 43.2 percent and 41.1 percent, respectively, were the worst of any 
region in the state over this period. Similar to the statewide industry, increases in induced contributions negated some of the impacts of the decreases in direct and indirect contributions. In 2017, the industry's direct contributions of output, employment, value added, and employee compensation accounted for 13.7 percent, 13.1 percent, 14.1 percent, and 14.7 percent of the totals of the industry statewide. In 2017, location quotients for the industry decreased to 0.48 for employment and 0.50 for value added showing that the regional economy had become even less concentrated in the industry than the state economy. Direct industry contributions of taxes also were lower than those in 2006 with \$3.9 million in state and local taxes and \$12.6 million in federal taxes.

Table 23. Contributions of the Region 2 forest products industry and associated SAM multipliers for years 2006 and 2017. Dollar amounts reported in 2017 dollars.

\begin{tabular}{|c|c|c|c|c|c|c|c|c|}
\hline \multirow[t]{2}{*}{ Contribution Type } & \multicolumn{2}{|c|}{ Output (\$MM) } & \multicolumn{2}{|c|}{ Employment } & \multicolumn{2}{|c|}{$\begin{array}{l}\text { Value Added } \\
\text { (\$MM) }\end{array}$} & \multicolumn{2}{|c|}{$\begin{array}{c}\text { Employee } \\
\text { Comp. }(\$ M M)\end{array}$} \\
\hline & 2006 & 2017 & 2006 & 2017 & 2006 & 2017 & 2006 & 2017 \\
\hline Direct & 535.0 & 303.7 & 2,221 & 1,334 & 147.3 & 105.9 & 100.8 & 59.4 \\
\hline Indirect & 131.4 & 89.9 & 825 & 571 & 48.6 & 47.4 & 23.3 & 22.1 \\
\hline Induced & 40.5 & 64.3 & 250 & 515 & 20.9 & 37.1 & 7.7 & 18.3 \\
\hline Total & 654.5 & 439.1 & 2,917 & 2,337 & 197.9 & 181.5 & 123.2 & 97.6 \\
\hline SAM Multiplier & 1.22 & 1.45 & 1.31 & 1.75 & 1.34 & 1.71 & 1.22 & 1.64 \\
\hline
\end{tabular}

\section{The North Central Region FPI Major Sectors}

The contributions of the region's individual FPI major sectors for the years 2006 and 2017 are presented in Table 24 and a comparison of the separate sectors' share of the region's overall industry direct output for 2006 and 2017 are shown in Figure 3. In 2006, the FPI in the North Central region was largely centered around the primary solid wood products sector. This sector's direct contributions of output, jobs, value added, and employment accounted for 42.3, 25.5, 43.5, and 43.3 percent of the industry total in the region, respectively. To a lesser extent, the region 
was also more highly concentrated in the wood furniture and pulp, paper, and paperboard sector than the statewide industry for this year. In 2006, the wood furniture sector provided the region with 17.1 percent of its direct FPI employment and 14 percent of its value added, or contribution to gross regional product. The pulp, paper, and paperboard industry provided 26 percent of industry direct output but just 8 percent of industry direct employment. The region's FPI was much less dependent on the secondary solid wood products sector than state-level industry in 2006 with sector providing just 8.9 percent of FPI direct output in the region, compared to 30.5 percent of that of the statewide industry. From 2006 to 2017, the industry's largest absolute losses of direct employment, value added, and employee compensation occurred in the primary solid wood products sector. Between these years, direct sector employment fell by 510 jobs, \$35.4 million in value added, and \$25.4 million in employee compensation, or 64.8 percent, 55.3 percent, and 58.1 percent from their 2006 levels, respectively. Despite these heavy losses, the sector still remained the largest contributor of direct output in the region, accounting for 42.5 percent of that of the industry's direct output. 
Figure 3. Forest products major sector share of overall FPI direct contributions of output for Region 2: 2006 vs 2017.

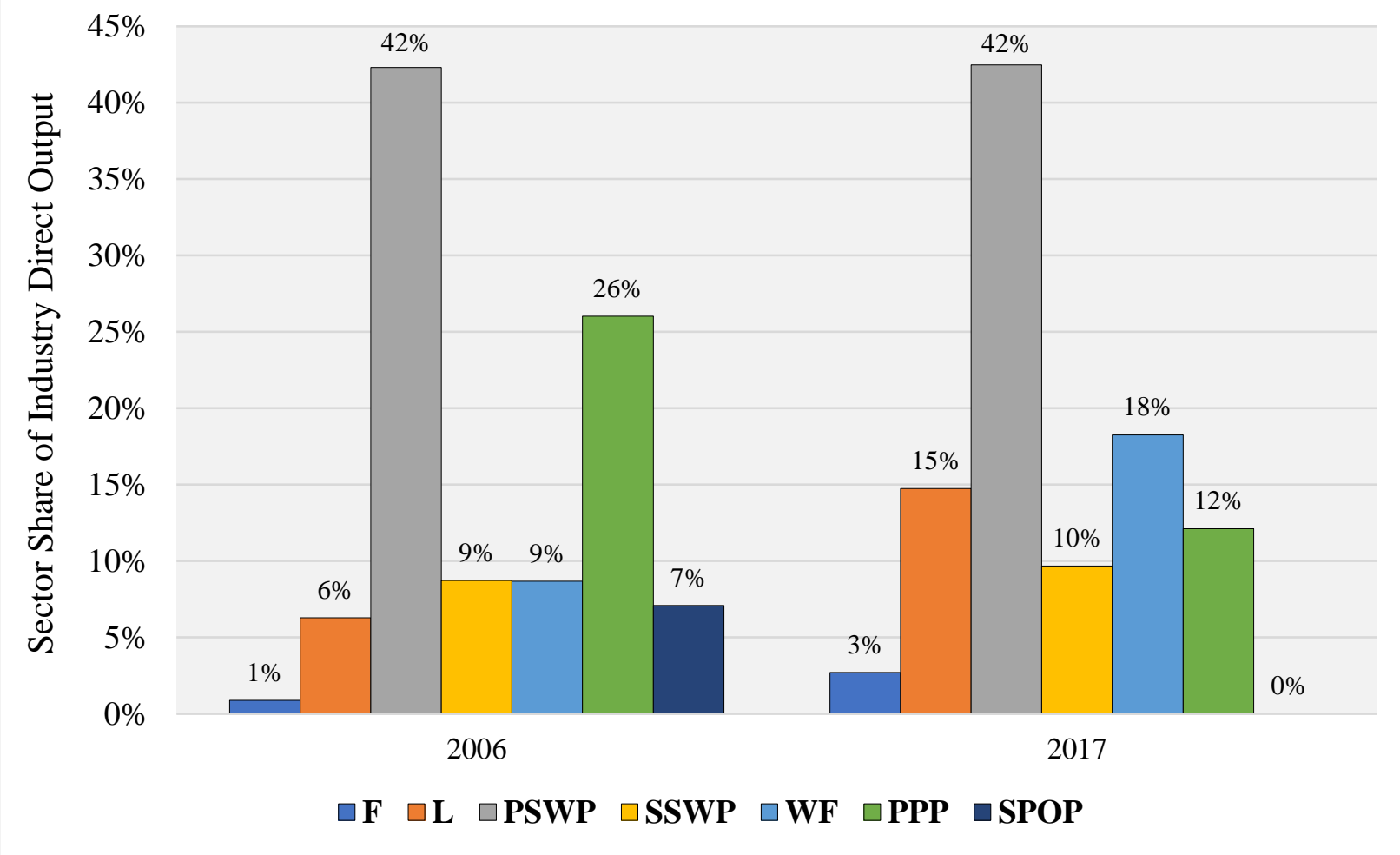

Meanwhile, some the largest percentage decreases of direct contributions in the industry were found in the region's pulp, paper, and paperboard sector which decreased by over 70 percent in terms of output, value added, and employee compensation, and by 66 percent in terms of employment. The regional industry's largest absolute decrease in output was found in this sector as well, with over \$102.4 million in direct output being lost between 2006 and 2017. By 2017, there was a complete loss of the region's secondary paperboard and other paper products sector which resulted in a loss of 127 direct jobs in the region. Alternately, the wood furniture sector was a relative bright spot for the region, as it experienced growth in direct contributions of output, employment, and employee compensation over this period. Despite a significant decrease in value added of 17 percent, the sector's share of the overall industry's direct contributions grew by all measures. By 2017, the sector accounted for 18.3 percent, 32 percent, 16.1 percent, and 
37.9 percent of the regional industry's direct output, employment, value added, and employee compensation, respectively. From 2006 to 2017, the North Central region was the only region in the state able to grow its wood furniture sector. Large growth was experienced in logging sector direct value added and output, despite decreases in employment and employee compensation. By 2017, the logging sector was the source of nearly 15 percent of FPI direct output in the region, an increase from just 6.3 percent in 2006. Immense percentage increases in forest sector contributions of all measures were also experienced, although the sector still remained a small portion of the region's FPI. These changes show a regional industry that has experienced some of the most severe losses in the FPI in the state from 2006 to 2017, largely due to the severe decreases in two of its most highly concentrated forest products sectors: primary solid wood products and pulp, paper, and paperboard. 
Table 24. Contributions of the Region 2 FPI major sectors and associated SAM multipliers for the year 2017. Dollar amounts reported in 2017 dollars.

\begin{tabular}{|c|c|c|c|c|c|c|c|c|c|c|c|c|c|c|}
\hline \multirow{2}{*}{ Contribution Type } & \multicolumn{2}{|c|}{$\mathbf{F}$} & \multicolumn{2}{|c|}{$\mathbf{L}$} & \multicolumn{2}{|c|}{ PSWP } & \multicolumn{2}{|c|}{ SSWP } & \multicolumn{2}{|c|}{ WF } & \multicolumn{2}{|c|}{ PPP } & \multicolumn{2}{|c|}{ SPOP } \\
\hline & 2006 & 2017 & 2006 & 2017 & 2006 & 2017 & 2006 & 2017 & 2006 & 2017 & 2006 & 2017 & 2006 & 2017 \\
\hline Direct & & & & & & & & & & & & & & \\
\hline Output (\$MM) & 4.8 & 8.2 & 33.6 & 44.8 & 226.3 & 128.9 & 46.7 & 29.4 & 46.4 & 55.5 & 139.2 & 36.8 & 38.0 & - \\
\hline Employment & 104 & 169 & 350 & 252 & 787 & 277 & 295 & 149 & 380 & 427 & 178 & 60 & 127 & - \\
\hline Value Added (\$MM) & 2.9 & 7.5 & 15.9 & 39.3 & 64.1 & 28.6 & 13.7 & 7.9 & 20.6 & 17.1 & 22.0 & 5.6 & 8.1 & - \\
\hline Employee Comp. (\$MM) & 1.2 & 4.1 & 4.6 & 3.8 & 43.7 & 18.3 & 10.7 & 6.2 & 16.4 & 22.5 & 16.8 & 4.4 & 7.4 & - \\
\hline Indirect & & & & & & & & & & & & & & \\
\hline Output (\$MM) & 0.4 & 0.3 & 6.5 & 2.7 & 78.1 & 45.5 & 11.3 & 10.0 & 7.8 & 15.4 & 33.7 & 16.3 & 3.6 & - \\
\hline Employment & 6 & 4 & 150 & 99 & 509 & 236 & 68 & 57 & 47 & 103 & 178 & 88 & 17 & - \\
\hline Value Added (\$MM) & 0.2 & 0.2 & 2.6 & 1.6 & 29.1 & 24.6 & 4.2 & 5.0 & 3.1 & 7.7 & 12.0 & 8.5 & 1.4 & - \\
\hline Employee Comp. (\$MM) & 0.05 & 0.10 & 0.9 & 0.8 & 13.2 & 10.5 & 2.4 & 2.6 & 1.7 & 4.2 & 5.9 & 4.0 & 0.8 & - \\
\hline Induced & & & & & & & & & & & & & & \\
\hline Output (\$MM) & 0.9 & 5.0 & 4.7 & 14.5 & 19.1 & 19.4 & 4.3 & 5.9 & 5.9 & 16.2 & 7.7 & 5.9 & 2.5 & - \\
\hline Employment & 5 & 40 & 29 & 117 & 118 & 156 & 26 & 47 & 36 & 129 & 48 & 48 & 16 & - \\
\hline Value Added (\$MM) & 0.4 & 2.9 & 2.5 & 8.4 & 9.9 & 11.2 & 2.2 & 3.4 & 3.0 & 9.3 & 4.0 & 3.4 & 1.3 & - \\
\hline Employee Comp. (\$MM) & 0.2 & 1.4 & 0.9 & 4.1 & 3.6 & 5.5 & 0.8 & 1.7 & 1.1 & 4.6 & 1.5 & 1.7 & 0.5 & - \\
\hline Total & & & & & & & & & & & & & & \\
\hline Output (\$MM) & 5.9 & 13.4 & 44.7 & 62.0 & 308.5 & 181.7 & 61.9 & 45.1 & 60.1 & 87.0 & 179.9 & 59.0 & 44.1 & - \\
\hline Employment & 114 & 211 & 528 & 468 & 1,354 & 643 & 387 & 252 & 464 & 660 & 402 & 195 & 160 & - \\
\hline Value Added (\$MM) & 3.5 & 10.5 & 20.9 & 49.2 & 99.0 & 62.3 & 20.1 & 16.2 & 26.7 & 34.2 & 37.9 & 17.5 & 10.9 & - \\
\hline Employee Comp. (\$MM) & 1.4 & 5.6 & 6.4 & 8.7 & 57.7 & 33.0 & 13.8 & 10.4 & 19.2 & 31.3 & 24.1 & 10.2 & 8.6 & - \\
\hline SAM Multiplier & & & & & & & & & & & & & & \\
\hline Output (\$MM) & 1.25 & 1.63 & 1.33 & 1.38 & 1.36 & 1.41 & 1.33 & 1.53 & 1.30 & 1.57 & 1.29 & 1.60 & 1.16 & - \\
\hline Employment & 1.10 & 1.25 & 1.51 & 1.86 & 1.72 & 2.32 & 1.31 & 1.69 & 1.22 & 1.54 & 2.26 & 3.24 & 1.26 & - \\
\hline Value Added (\$MM) & 1.21 & 1.40 & 1.32 & 1.25 & 1.55 & 2.17 & 1.46 & 2.06 & 1.30 & 2.00 & 1.72 & 3.14 & 1.34 & - \\
\hline Employee Comp. (\$MM) & 1.18 & 1.36 & 1.39 & 2.29 & 1.32 & 1.80 & 1.29 & 1.68 & 1.17 & 1.39 & 1.43 & 2.29 & 1.17 & - \\
\hline
\end{tabular}




\subsubsection{Region 3 - Highlands Region}

\section{The Highlands Region FPI}

Region 3, the Highlands region, consists of eleven counties, four of which share their eastern border with Virginia and one which shares borders with both Maryland and Pennsylvania. Most of the Monongahela National Forest is located within this region, as well as small portions of the George Washington National Forest. The West Virginia Hardwood Alliance Zone, which entails 8 of the 11 counties in the region, provides business development and expansion assistance to FPI firms and illustrates the importance of the hardwood forests to the region's economy. While the region has a historically strong forest products presence, the region's forests also play a role in the tourism and recreation activities which draw tourists from neighboring states to the region. Moving into the future, the ability of the FPI in the region to co-exist with and benefit from the region's tourism and outdoor recreation sectors is crucial. In 2006, this region's FPI was, by far, the largest of any of the regions analyzed, contributing 41.4 percent of the statewide industry's direct employment and 41.9 percent of the industry's statewide value added. The industry's economic contributions to the region in 2006 and 2017 are presented in Table 25. The region's industry location quotients were 1.46 for employment and 1.48 for value added, illustrating that the region's economy was much more highly concentrated in the FPI than was the state economy. In 2006, 51.1 percent of the statewide direct output of the logging sector took place within the region, and 61.6 percent of the statewide direct output of the secondary solid wood products sector. Industry direct contributions of taxes of the region were $\$ 11.4$ million in state and local taxes and \$51.6 million in federal taxes for the year. Between 2006 and 2017, the Highlands region's FPI fared much than the rest of the state, even with still considerable losses in all measures of direct contributions. Despite the regional industry's percentage loss of 30.4 
percent of employee compensation being the lowest of any region, the absolute loss was, by far, the highest, due to the large nature of the industry in the region. By measures of direct output and value added, the regional industry fared much better than the rest of the state, with losses of just 4.9 percent and 3 percent, respectively, while all other regions saw double-digit percentage decreases. By 2017, direct contributions of the region's FPI were 44.7 percent, 43.1 percent, 48.6 percent, and 44.1 percent of the statewide FPI contributions of output, employment, value added, and employee compensation, respectively. These direct contributions accounted for 1.8 percent of all employment in the region and 1.7 percent of the region's contribution to gross state product. Moreover, total contributions to the broader regional economy show the industry supported 2.8 percent of all jobs in the region and 2.4 percent of all value added. Location quotients for the industry grew from 2006 values to 1.57 for employment and 1.73 for value added, representing a regional economy that was, by far, the most heavily concentrated in the FPI, as compared to the state economy. SAM multipliers of all measures of contribution also grew over this period, reflecting an industry that has become more highly integrated into the regional economy. Direct contributions of taxes for the industry in the region decreased from 2006 to 2017 to $\$ 9.2$ million in state and local taxes and $\$ 37.1$ million in federal taxes.

Table 25. Contributions of the Region 3 forest products industry and associated SAM multipliers for years 2006 and 2017. Dollar amounts reported in 2017 dollars.

\begin{tabular}{|l|r|r|r|r|r|r|r|r|}
\hline Contribution Type & \multicolumn{2}{|c|}{ Output $\mathbf{( \$ M M )}$} & \multicolumn{2}{c|}{ Employment } & \multicolumn{2}{c|}{$\begin{array}{c}\text { Value Added } \\
\text { (\$MM) }\end{array}$} & \multicolumn{2}{c|}{$\begin{array}{c}\text { Employee } \\
\text { Comp. (\$MM) }\end{array}$} \\
\hline & \multicolumn{1}{|c|}{2006} & \multicolumn{1}{|c|}{2017} & \multicolumn{1}{|c|}{2006} & \multicolumn{1}{|c|}{2017} & \multicolumn{1}{c|}{2006} & \multicolumn{1}{c|}{2017} & 2006 & \multicolumn{1}{c|}{2017} \\
\cline { 2 - 9 } Direct & $1,042.1$ & 991.5 & 6,210 & 4,395 & 375.9 & 364.6 & 256.7 & 178.6 \\
Indirect & 266.0 & 343.1 & 1,799 & 2,003 & 106.2 & 179.3 & 54.5 & 63.8 \\
Induced & 68.4 & 148.7 & 393 & 1,363 & 35.4 & 81.5 & 10.5 & 37.4 \\
Total & $1,185.3$ & $1,305.2$ & 7,077 & 6,955 & 440.7 & 526.7 & 282.9 & 255.0 \\
\hline SAM Multiplier & 1.14 & 1.32 & 1.14 & 1.58 & 1.17 & 1.44 & 1.10 & 1.43 \\
\hline
\end{tabular}




\section{The Highlands Region FPI Major Sectors}

The contributions of the region's individual FPI major sectors for the years 2006 and 2017 are presented in Table 26 and a comparison of the separate sectors' share of the region's overall industry direct output for 2006 and 2017 are shown in Figure 4. In 2006, the FPI in the Highlands regions was highly concentrated in the secondary solid wood products sector, with the sector contributing over 50 percent of the regional industry's direct output and employee compensation, and over 45 percent of its direct employment and value added. These direct contributions of the secondary solid wood products in the region accounted for a majority of the contributions of the sector statewide. Similarly, logging sector direct contributions in the region accounted for over or just under 50 percent of all of that in the state, despite accounting for just 12.2 percent, 19.2 percent, 17.9 percent, and 9.6 percent of the industry's direct contributions of output, employment, value added, and employee compensation in the region, respectively. The region was also concentrated in the primary solid wood products sector in 2006, although less so than the industry statewide. While the region's wood furniture sector was quite large, the region was also less highly concentrated in the sector than the statewide industry. In 2006, there was no sector activity in the two pulp and paper-related sectors. From 2006 to 2017, much like the industry statewide, the FPI in the region experienced its largest absolute decreases in both the direct and total contributions of its secondary solid wood products sector. Over this period, the sector's direct contributions of all measures decreased by more than or just under 50 percent. This resulted in a loss of $\$ 259.1$ million in direct sector sales, 1,522 jobs, $\$ 106$ million of gross regional product, and $\$ 70.6$ million of employee compensation in the region. Even larger percentage losses were experienced in the wood furniture sector, which declined by 53 percent in terms of direct output, 58.4 percent in terms of direct employment, an immense 72.3 percent in 
direct value added, and 61.1 percent in employee compensation. The region's logging sector fared relatively better over this period growing immensely in terms of output and value added, while contracting by measures of direct employment and employee compensation. While the region's secondary solid wood products sector contracted, the region transitioned into its primary solid wood products sector, as the sector grew by all measures of contribution over this period. By 2017, the sector accounted for 46.1 percent of the regional industry's direct output, 37.4 percent of its direct employment. 24.3 percent of its direct value added, and 42.5 percent of its employee compensation.

Figure 4. Forest products major sector share of overall FPI direct contributions of output for Region 3: 2006 vs 2017.

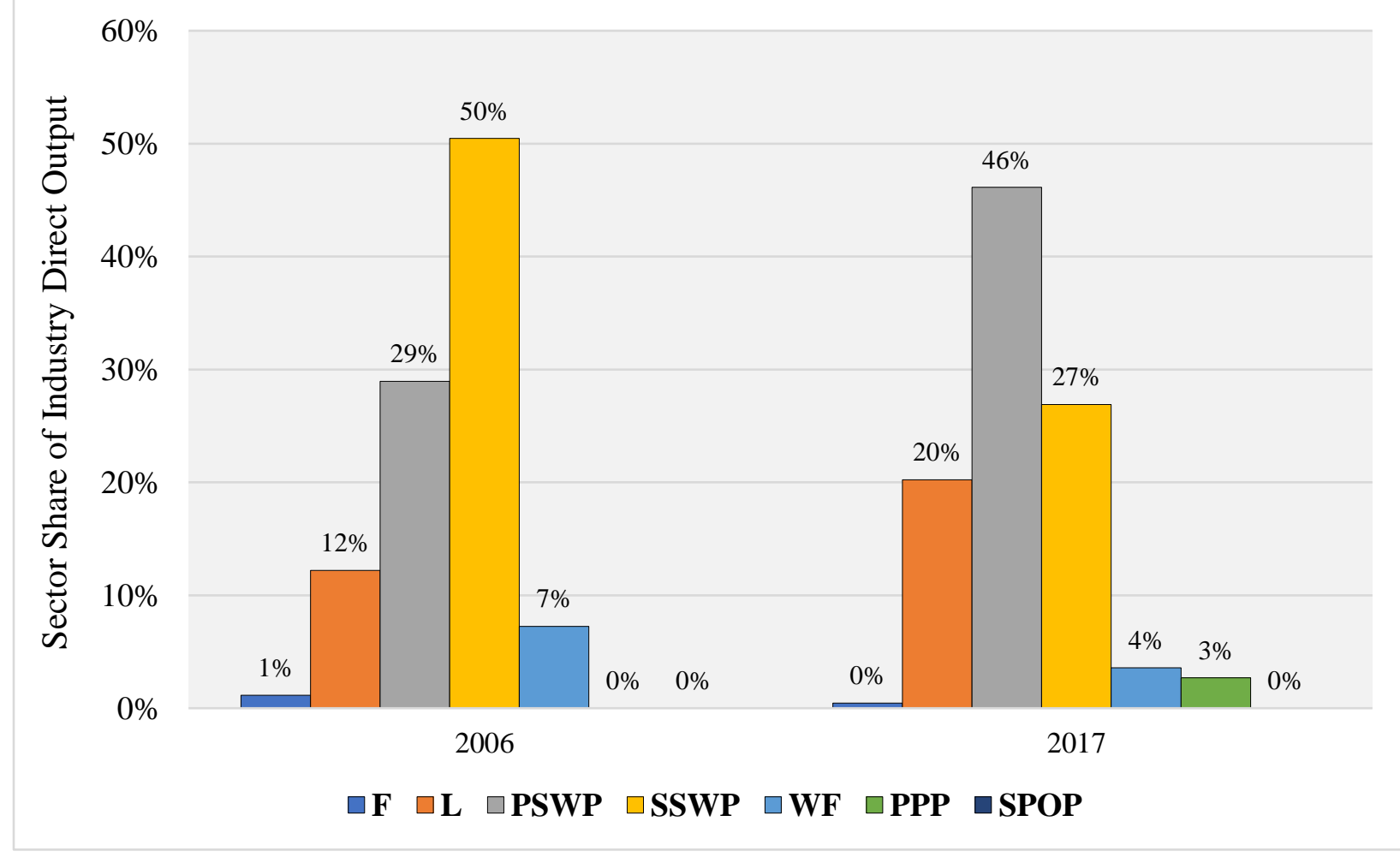

SAM multiplier values of the sector also grew particularly in the case of value added, reaching a 2017 value of 2.88. The region was also able to attract pulp, paper, and paperboard sector 
activity to the region over this period, although the sector made up a small portion of the region's overall industry in 2017. By 2017, the region's primary solid wood products, secondary solid wood products, and logging sectors' direct contributions accounted for well above or just under 50 percent of those of the industry statewide, reflecting the immense importance of this region to the statewide industry. The ability of the region to transition into its primary solid wood products sector while experiencing large decreases in its secondary solid wood products and wood furniture sectors helped the region fare better than the other regions in the state and boosted the statewide industry's contributions over this period. However, steps should be taken to revitalize the region's secondary solid wood products and wood furniture sectors as growth in these sectors would increase inter-sector FPI activity throughout the state. As the region is likely to continue to serve as the central hub of the state's FPI, steps should also be taken to provide the regional industry with a healthy and highly-skilled workforce. 
Table 26. Contributions of the Region 3 FPI major sectors and associated SAM multipliers for the year 2017. Dollar amounts reported in 2017 dollars.

\begin{tabular}{|c|c|c|c|c|c|c|c|c|c|c|c|c|c|c|}
\hline \multirow{2}{*}{ Contribution Type } & \multicolumn{2}{|c|}{$\mathbf{F}$} & \multicolumn{2}{|c|}{$\mathbf{L}$} & \multicolumn{2}{|c|}{ PSWP } & \multicolumn{2}{|c|}{ SSWP } & \multicolumn{2}{|c|}{ WF } & \multicolumn{2}{|c|}{ PPP } & \multicolumn{2}{|c|}{ SPOP } \\
\hline & 2006 & 2017 & 2006 & 2017 & 2006 & 2017 & 2006 & 2017 & 2006 & 2017 & 2006 & 2017 & 2006 & 2017 \\
\hline Direct & & & & & & & & & & & & & & \\
\hline Output (\$MM) & 11.9 & 4.4 & 127.1 & 200.7 & 301.6 & 457.3 & 525.9 & 266.8 & 75.6 & 35.5 & - & 26.8 & - & - \\
\hline Employment & 168 & 157 & 1,192 & 979 & 1,363 & 1,643 & 2,812 & 1,290 & 674 & 281 & - & 45 & - & - \\
\hline Value Added (\$MM) & 8.4 & 3.7 & 67.3 & 179.2 & 83.1 & 88.6 & 187.4 & 81.4 & 29.8 & 8.2 & - & 3.4 & - & - \\
\hline Employee Comp. (\$MM) & 3.3 & 3.2 & 24.7 & 21.2 & 66.3 & 75.9 & 135.9 & 65.3 & 26.5 & 10.3 & - & 2.6 & - & - \\
\hline Indirect & & & & & & & & & & & & & & \\
\hline Output (\$MM) & 0.6 & 0.2 & 14.6 & 7.2 & 134.4 & 235.8 & 145.6 & 104.3 & 11.1 & 9.2 & - & 11.4 & - & - \\
\hline Employment & 5 & 4 & 154 & 161 & 1,011 & 1,326 & 895 & 583 & 69 & 61 & - & 65 & - & - \\
\hline Value Added (\$MM) & 0.3 & 0.1 & 6.3 & 3.8 & 59.2 & 135.5 & 53.9 & 44.8 & 4.1 & 3.9 & - & 5.3 & - & - \\
\hline Employee Comp. (\$MM) & 0.07 & 0.07 & 2.5 & 2.0 & 26.7 & 41.6 & 30.4 & 20.4 & 2.5 & 2.0 & - & 2.3 & - & - \\
\hline Induced & & & & & & & & & & & & & & \\
\hline Output (\$MM) & 1.8 & 2.0 & 13.7 & 48.1 & 23.6 & 72.3 & 37.6 & 45.9 & 6.5 & 6.1 & - & 3.1 & - & - \\
\hline Employment & 10 & 18 & 78 & 442 & 136 & 663 & 216 & 420 & 37 & 56 & - & 28 & - & - \\
\hline Value Added (\$MM) & 0.9 & 1.1 & 7.1 & 26.4 & 12.2 & 39.6 & 19.5 & 25.1 & 3.4 & 3.3 & - & 1.7 & - & - \\
\hline Employee Comp. (\$MM) & 0.3 & 0.5 & 2.1 & 12.1 & 3.6 & 18.2 & 5.8 & 11.5 & 1.0 & 1.5 & - & 0.8 & - & - \\
\hline Total & & & & & & & & & & & & & & \\
\hline Output (\$MM) & 14.1 & 6.6 & 154.9 & 256.0 & 431.6 & 720.4 & 695.3 & 411.9 & 93.2 & 50.8 & - & 41.2 & - & - \\
\hline Employment & 182 & 177 & 1,419 & 1,581 & 2,385 & 3,466 & 3,849 & 2,269 & 781 & 397 & - & 138 & - & - \\
\hline Value Added (\$MM) & 9.5 & 4.9 & 80.4 & 209.4 & 146.9 & 255.3 & 256.0 & 149.9 & 37.3 & 15.5 & - & 10.4 & - & - \\
\hline Employee Comp. (\$MM) & 3.6 & 3.8 & 29.3 & 35.3 & 90.7 & 128.4 & 169.1 & 96.2 & 30.0 & 13.9 & - & 5.7 & - & - \\
\hline SAM Multiplier & & & & & & & & & & & & & & \\
\hline Output (\$MM) & 1.19 & 1.49 & 1.22 & 1.28 & 1.43 & 1.58 & 1.32 & 1.54 & 1.23 & 1.43 & - & 1.54 & - & - \\
\hline Employment & 1.08 & 1.13 & 1.19 & 1.62 & 1.75 & 2.11 & 1.37 & 1.76 & 1.16 & 1.41 & - & 3.05 & - & - \\
\hline Value Added (\$MM) & 1.14 & 1.32 & 1.19 & 1.17 & 1.77 & 2.88 & 1.37 & 1.84 & 1.25 & 1.88 & - & 3.06 & - & - \\
\hline Employee Comp. (\$MM) & 1.09 & 1.17 & 1.18 & 1.67 & 1.37 & 1.69 & 1.24 & 1.47 & 1.13 & 1.34 & - & 2.19 & - & - \\
\hline
\end{tabular}




\subsubsection{Region 4 - Eastern Panhandle Region}

\section{The Eastern Panhandle Region FPI}

Region 4, the Eastern Panhandle region, consists of seven counties which, as the name implies, make up the eastern panhandle of West Virginia in which all counties share at least one border with Maryland and/or Virginia. This region's economy, particularly in the counties farther east, has increasingly benefitted from its proximity to the greater Washington D.C. metro area. While the regional economy has been relatively strong in recent years, many of its economic development resources have gone toward attracting large businesses such as Proctor \& Gamble and Macy's. Thus, the strong economic performance of the region has not been experienced in the FPI specifically. As the D.C. metro area is likely to continue to expand into the region in future, the regional FPI's ability to adapt to expanding urbanization will play a large role in the industry's future. In 2006, the region's FPI was the second largest in the state, by all measures of direct contributions. The direct industry contributions in the region of output, employment, value added, and employee compensation accounted for 19.3 percent, 18.8 percent, 17.9 percent, and 18.5 percent of the totals of those of the statewide industry, respectively. The 2,823 jobs directly contributed by the FPI in the region accounted for 1.1 percent of all employment in the region, while the total contribution of the industry to the broader regional economy supported 1.2 percent of all jobs. Correspondingly, direct industry value added accounted for 0.8 percent of all of gross regional product while total industry contributions of value added accounted for 1 percent of that of the region. Location quotients were 0.67 for direct employment and 0.63 for direct value added, suggesting that the region's economy was less concentrated in the FPI overall than the state economy in 2006. SAM multiplier values were found to be lower than those of the regional industry averages for 2006 by every measure, suggesting that a relatively larger amount 
of the inter-industry activity and spending of personal income by FPI workers and proprietors occur outside of the region. Direct contributions of taxes by the industry for the year were $\$ 5.2$ million in state and local taxes and \$23.9 million in federal taxes. From 2006 to 2017 , the overall FPI in region experienced significant decreases in direct contributions of every measure (Table 27). The percentage losses in industry direct contributions were more severe than those of the statewide industry by every measure. Increases in associated SAM multiplier values reflect the large growth in induced contributions the industry made in the broader regional economy. Despite these increases, SAM multiplier values were still below those of the statewide industry for all measures. By 2017, the direct contributions of the regional industry in terms of output, jobs, value added, and employee compensation accounted for 15.8 percent, 18.8 percent, 14.5 percent and 18 percent of those of the statewide FPI, respectively. Industry direct employment accounted for 0.8 percent of all jobs in the region while industry direct contribution of value added accounted for 0.5 percent of gross regional product. Corresponding figures for total contributions of employment and value added were 1.2 percent and 0.8 percent, respectively. A marginal increase in the location quotient for the industry in terms of employment and a decrease in terms of value added, suggest the region's economy was still much less concentrated in the FPI than the overall state economy. In 2017 , the industry in the region directly contributed $\$ 3.6$ million in state and local taxes and \$14.7 million in federal taxes.

Table 27. Contributions of the Region 4 forest products industry and associated SAM multipliers for years 2006 and 2017. Dollar amounts reported in 2017 dollars.

\begin{tabular}{|l|r|r|r|r|r|r|r|r|}
\hline \multirow{2}{*}{ Contribution Type } & \multicolumn{2}{|c|}{ Output $\mathbf{( \$ M M )}$} & \multicolumn{2}{c|}{ Employment } & \multicolumn{2}{c|}{$\begin{array}{c}\text { Value Added } \\
\text { (\$MM) }\end{array}$} & \multicolumn{2}{c|}{$\begin{array}{c}\text { Employee } \\
\text { Comp. (\$MM) }\end{array}$} \\
\hline & \multicolumn{1}{|c|}{2006} & \multicolumn{1}{|c|}{2017} & \multicolumn{1}{|c|}{2006} & \multicolumn{1}{|c|}{2017} & \multicolumn{1}{c|}{2006} & \multicolumn{1}{c|}{2017} & \multicolumn{1}{c|}{2006} & 2017 \\
\cline { 2 - 9 } Direct & 540.5 & 350.2 & 2,823 & 1,914 & 160.6 & 108.8 & 114.7 & 72.8 \\
Indirect & 106.6 & 95.7 & 640 & 636 & 39.6 & 49.7 & 22.5 & 22.1 \\
Induced & 27.4 & 55.3 & 121 & 478 & 14.5 & 30.6 & 3.7 & 13.5 \\
Total & 611.9 & 475.8 & 3,185 & 2,905 & 194.3 & 175.8 & 128.3 & 104.9 \\
\hline SAM Multiplier & 1.13 & 1.36 & 1.13 & 1.52 & 1.21 & 1.62 & 1.12 & 1.44 \\
\hline
\end{tabular}




\section{The Eastern Panhandle Region FPI Major Sectors}

The contributions of the region's individual FPI major sectors for the years 2006 and 2017 are presented in Table 28 and a comparison of the separate sectors' share of the region's overall industry direct output for 2006 and 2017 are shown in Figure 5. In 2006, the region's FPI was largely concentrated in the primary solid wood products sector. The sector contributed over half of the industry's direct contributions of output, value added, and employee compensation in the region. The region was more highly concentrated in the sector than was the statewide industry, with approximately 30 percent of the state primary solid wood products sector's direct contributions occurring in the region in 2006. Alternately, the sector was much less concentrated in the secondary solid wood products and logging sectors than was the state for this year.

Additionally, there was no secondary paperboard and other paper products sector activity in the region in 2006. From 2006 to 2017, the largest losses in both relative and absolute terms were found in the region's largest sector in 2006, the primary solid wood products sector. Between these years, the sector's direct contributions of output, employment, value added, and employee compensation decreased by 67.4 percent, 79.2 percent, 74.8 percent, and 76 percent, respectively. 
Figure 5. Forest products major sector share of overall FPI direct contributions of output for Region 4: 2006 vs 2017.

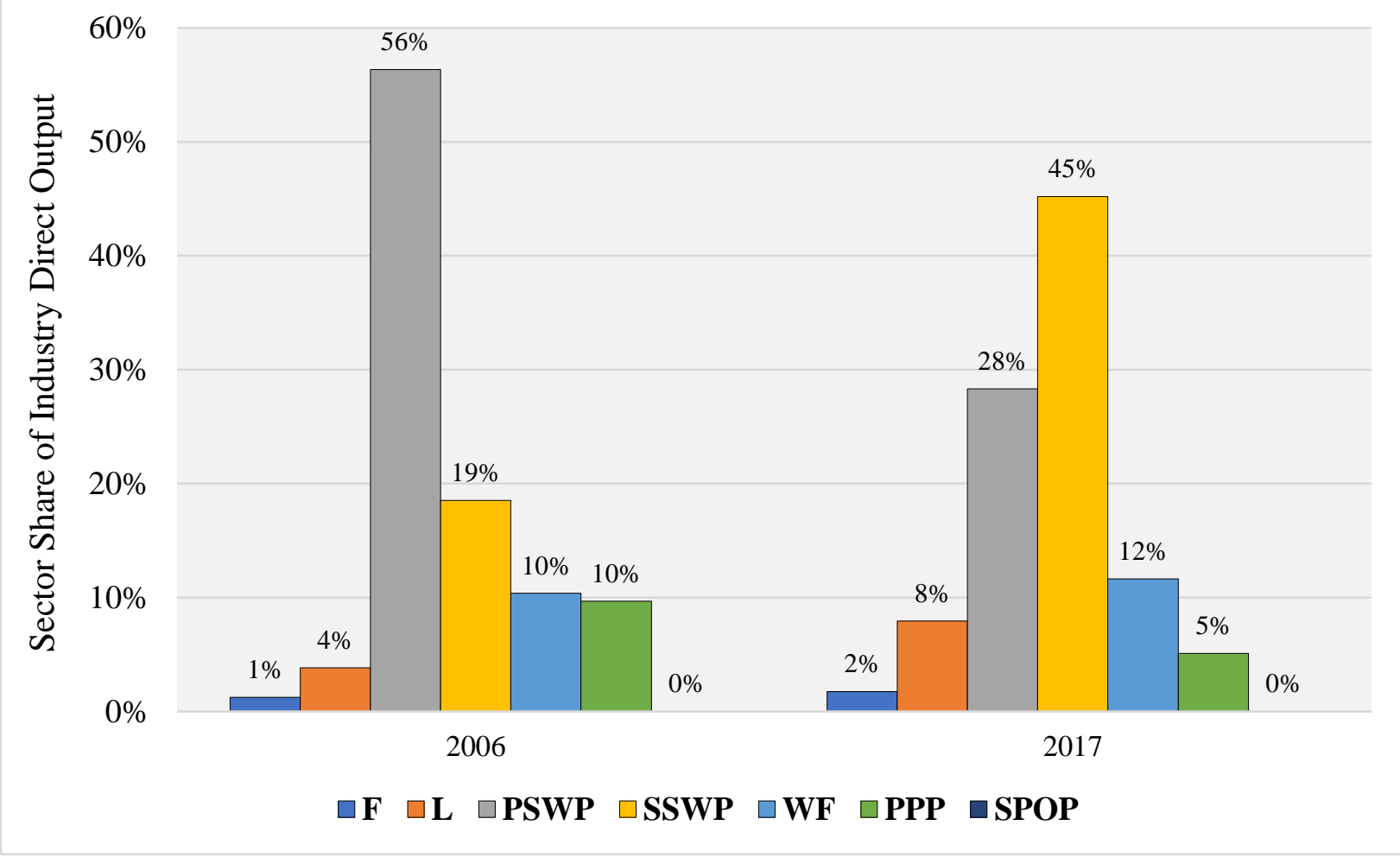

By 2017, the region's primary solid wood sector's direct output accounted for only 11.3 percent of the sector's statewide total, down from 29.3 percent in 2006. Alternately, the region's secondary solid wood products sector was able to grow over this period. This transition away from primary solid wood products and into secondary solid wood products was the opposite approach of that of the Highlands region between these years. This made the region the only one in the state to experience growth in its secondary solid wood products sector over this time. The increases in the sector, however, were not large enough to compensate for the losses experienced in the primary solid wood products sector. Decreases in contributions of the pulp, paper, and paperboard sector resulted the region accounting for just 11.9 percent of the sector's statewide direct output in 2017, down from 22.8 percent in 2006. Decreases were also experienced in the 
wood furniture sector, although they were less severe than those of the industry overall for every measure except value added, which was also the case across the rest of the regions in the state. By 2017, we find a regional industry that is much less concentrated in the primary solid wood products, while much more highly concentrated in secondary solid wood products than in 2006. Despite this transition, the losses of the FPI in the Eastern Panhandle region were some of the largest experienced in the state by both percentage and absolute decreases. However, as of 2017, the region continued to have the second largest FPI of all regions analyzed. 
Table 28. Contributions of the Region 4 FPI major sectors and associated SAM multipliers for the year 2017. Dollar amounts reported in 2017 dollars.

\begin{tabular}{|c|c|c|c|c|c|c|c|c|c|c|c|c|c|c|}
\hline \multirow{2}{*}{ Contribution Type } & \multicolumn{2}{|c|}{$\mathbf{F}$} & \multicolumn{2}{|c|}{$\mathbf{L}$} & \multicolumn{2}{|c|}{ PSWP } & \multicolumn{2}{|c|}{ SSWP } & \multicolumn{2}{|c|}{ WF } & \multicolumn{2}{|c|}{ PPP } & \multicolumn{2}{|c|}{ SPOP } \\
\hline & 2006 & 2017 & 2006 & 2017 & 2006 & 2017 & 2006 & 2017 & 2006 & 2017 & 2006 & 2017 & 2006 & 2017 \\
\hline Direct & & & & & & & & & & & & & & \\
\hline Output (\$MM) & 6.7 & 6.2 & 20.8 & 27.8 & 304.5 & 99.2 & 100.1 & 158.3 & 56.0 & 40.8 & 52.3 & 17.9 & - & - \\
\hline Employment & 134 & 225 & 222 & 152 & 1,336 & 278 & 592 & 869 & 442 & 366 & 99 & 25 & - & - \\
\hline Value Added (\$MM) & 4.0 & 5.1 & 9.5 & 24.5 & 81.9 & 20.7 & 34.0 & 46.8 & 23.3 & 9.7 & 7.9 & 2.1 & - & - \\
\hline Employee Comp. (\$MM) & 2.4 & 4.4 & 4.4 & 2.5 & 60.9 & 14.6 & 23.7 & 36.2 & 17.7 & 13.6 & 5.6 & 1.4 & - & - \\
\hline Indirect & & & & & & & & & & & & & & \\
\hline Output (\$MM) & 0.4 & 0.3 & 3.5 & 1.7 & 76.5 & 36.8 & 19.8 & 44.8 & 6.1 & 9.8 & 6.8 & 6.3 & - & - \\
\hline Employment & 6 & 6 & 56 & 37 & 484 & 233 & 103 & 289 & 36 & 71 & 27 & 37 & - & - \\
\hline Value Added (\$MM) & 0.2 & 0.2 & 1.4 & 1.0 & 28.7 & 21.1 & 7.0 & 21.9 & 2.4 & 4.7 & 2.5 & 3.2 & - & - \\
\hline Employee Comp. (\$MM) & 0.08 & 0.12 & 0.7 & 0.4 & 16.1 & 8.0 & 4.3 & 10.5 & 1.3 & 2.5 & 1.3 & 1.4 & - & - \\
\hline Induced & & & & & & & & & & & & & & \\
\hline Output (\$MM) & 0.7 & 2.8 & 1.8 & 7.7 & 15.7 & 14.1 & 6.0 & 25.7 & 4.1 & 7.6 & 1.5 & 2.0 & - & - \\
\hline Employment & 3 & 24 & 8 & 66 & 69 & 122 & 27 & 223 & 18 & 66 & 6 & 17 & - & - \\
\hline Value Added (\$MM) & 0.4 & 1.5 & 0.9 & 4.2 & 8.3 & 7.8 & 3.2 & 14.3 & 2.2 & 4.2 & 0.8 & 1.1 & - & - \\
\hline Employee Comp. (\$MM) & 0.1 & 0.7 & 0.2 & 1.9 & 2.1 & 3.5 & 0.8 & 6.3 & 0.6 & 1.9 & 0.2 & 0.5 & - & - \\
\hline Total & & & & & & & & & & & & & & \\
\hline Output (\$MM) & 7.8 & 9.2 & 26.0 & 37.2 & 366.9 & 146.0 & 125.1 & 227.5 & 66.2 & 58.3 & 60.6 & 26.2 & - & - \\
\hline Employment & 141 & 251 & 286 & 255 & 1,757 & 619 & 717 & 1,373 & 495 & 504 & 133 & 79 & - & - \\
\hline Value Added (\$MM) & 4.5 & 6.7 & 11.9 & 29.8 & 111.1 & 48.8 & 43.9 & 82.6 & 27.9 & 18.6 & 11.2 & 6.4 & - & - \\
\hline Employee Comp. (\$MM) & 2.6 & 5.2 & 5.4 & 4.8 & 73.4 & 25.4 & 28.7 & 52.7 & 19.6 & 18.0 & 7.1 & 3.3 & - & - \\
\hline SAM Multiplier & & & & & & & & & & & & & & \\
\hline Output (\$MM) & 1.15 & 1.49 & 1.25 & 1.34 & 1.20 & 1.47 & 1.25 & 1.44 & 1.18 & 1.43 & 1.16 & 1.46 & - & - \\
\hline Employment & 1.05 & 1.12 & 1.29 & 1.68 & 1.32 & 2.22 & 1.21 & 1.58 & 1.12 & 1.38 & 1.34 & 3.20 & - & - \\
\hline Value Added (\$MM) & 1.13 & 1.33 & 1.25 & 1.21 & 1.36 & 2.36 & 1.29 & 1.76 & 1.20 & 1.92 & 1.42 & 3.05 & - & - \\
\hline Employee Comp. (\$MM) & 1.06 & 1.17 & 1.21 & 1.89 & 1.20 & 1.74 & 1.21 & 1.46 & 1.11 & 1.32 & 1.27 & 2.39 & - & - \\
\hline
\end{tabular}




\subsubsection{Region 5 - Southern Region}

Region 5, the Southern region, is made up of twelve counties in Southwestern West Virginia, four of which share a border with either Kentucky or Virginia. Although much of the region is very rural and has immense forest resources, the regional economy benefits greatly from the urban center of Charleston, the state's capital. Historically, the region's economy has largely revolved around the coal industry which has been in steady decline over recent decades.

Particularly, with the slowdown in foreign demand for coal and the increase in natural gas energy production, the region's economy has suffered severely in recent years and has become more highly dependent on the economic activity derived from Charleston and the tourism industry. While the region has a large amount of forest resources, the particularly steep terrain of the region makes mechanized logging operations difficult which results in the use of less efficient manual timber felling. The economic contributions made by the overall FPI in the region for the years 2006 and 2017 are listed in Table 29. In 2006, the region had the second smallest FPI by all measure of direct contribution, larger than only the Ohio River region. The 2,049 jobs located directly in the FPI in the region accounted for 0.8 percent of all jobs in the region while the direct contribution of value added made by the industry of $\$ 125.9$ million accounted for 0.6 percent of that of the region. The total contributions made by the industry of employment and value added to the broader regional economy accounted for 1.0 percent and 0.9 percent of those of the region, respectively. Location quotients of 0.48 for direct employment and 0.50 for value added reveal that the region's economy was less concentrated in the FPI than was the economy of the state. SAM multiplier values for the overall industry of the region were found to be higher than the regional industry average which indicate that the industry in this region was more effective at spurring economic activity in the broader economy than other regions. Direct industry 
contributions of business taxes from the region were $\$ 4.2$ million in state and local taxes and \$16.9 million in federal taxes. From 2006 to 2017, direct contributions of the industry in the region were down by all measures. However, the percentage decreases in direct contributions were less than those of the statewide industry over this period for every measure except employee compensation. These relatively less sever decreases, paired with the immense decreases experienced in the Ohio River and North Central regions over this period, led to the Southern region becoming the $3^{\text {rd }}$ largest regional FPI in the state in 2017, behind only the Highlands and Eastern Panhandle regions. Increases in indirect and induced contributions resulted in an increase in total contributions of output and value added. This region was one of only two in the state to witness increases in multiple measures of industry total contribution. In both regions (the other being the Highlands region), the increases were in terms of output and value added. The discrepancy between regional industry production and jobs and employee compensation may be indicative of increased automation throughout the industry over this period. In 2017, the direct contributions of the region's FPI of output, employment, value added, and employee compensation accounted for 14.3 percent, 15.2 percent, 14.9 percent, and 12.9 percent of those of the statewide industry, respectively, which were all higher than corresponding 2006 values except in the case of employee compensation. The industry's total contribution of 2,579 jobs accounted for $1.1 \%$ of all jobs in the region while the industry's total contribution of value added made up 0.9 percent of the gross regional product in 2017. Location quotients for the industry increased from 2006 values to 0.55 for employment and 0.53 for value added showing that, while the region had become more heavily concentrated in the industry, the region's economy was still less dependent on the industry than the state economy. Direct 
industry contributions of taxes were lover than 2006 values with $\$ 3$ million in state and local taxes and \$11.1 million in federal taxes for the year.

Table 29. Contributions of the Region 5 forest products industry and associated SAM multipliers for years 2006 and 2017. Dollar amounts reported in 2017 dollars.

\begin{tabular}{|c|c|c|c|c|c|c|c|c|}
\hline \multirow[t]{2}{*}{ Contribution Type } & \multicolumn{2}{|c|}{ Output (\$MM) } & \multicolumn{2}{|c|}{ Employment } & \multicolumn{2}{|c|}{$\begin{array}{l}\text { Value Added } \\
\text { (\$MM) }\end{array}$} & \multicolumn{2}{|c|}{$\begin{array}{c}\text { Employee } \\
\text { Comp. }(\$ M M)\end{array}$} \\
\hline & 2006 & 2017 & 2006 & 2017 & 2006 & 2017 & 2006 & 2017 \\
\hline & & & & & 125.9 & 111.9 & 84.3 & 52.2 \\
\hline & 100 & 119 & & & 46.8 & 70.4 & 26.2 & 29.2 \\
\hline Induc & 44 & & & & 24.8 & 39.7 & 10.6 & 19.9 \\
\hline Total & 460.6 & 466.1 & 2,689 & 2,579 & 177.0 & 197.5 & 109.5 & 96.3 \\
\hline SAM Multiplier & 1.26 & 1.47 & 1.31 & 1.66 & 1.41 & 1.76 & 1.30 & 1.84 \\
\hline
\end{tabular}

The Southern Region FPI Major Sectors

The contributions of the region's individual FPI major sectors for the years 2006 and 2017 are presented in Table $\mathbf{3 0}$ and a comparison of the separate sectors' share of the region's overall industry direct output for 2006 and 2017 are shown in Figure 6. In 2006, the industry in the Southern region was centered around the primary solid wood products sector. The sector accounted for 51 percent, 32.8 percent, 42.1 percent, and 42.6 percent of the regional industry's direct contributions of output, employment, value added, and employee compensation, respectively. By all measures of direct contribution, the region was more heavily concentrated in the sector than the statewide industry, while the region was slightly less heavily concentrated in the secondary solid wood products sector than the state. Similarly, the region's industry was somewhat more highly concentrated in the logging and wood furniture sectors, while being less concentrated in the pulp and paper-related sectors. 
Figure 6. Forest products major sector share of overall FPI direct contributions of output for Region 5: 2006 vs 2017.

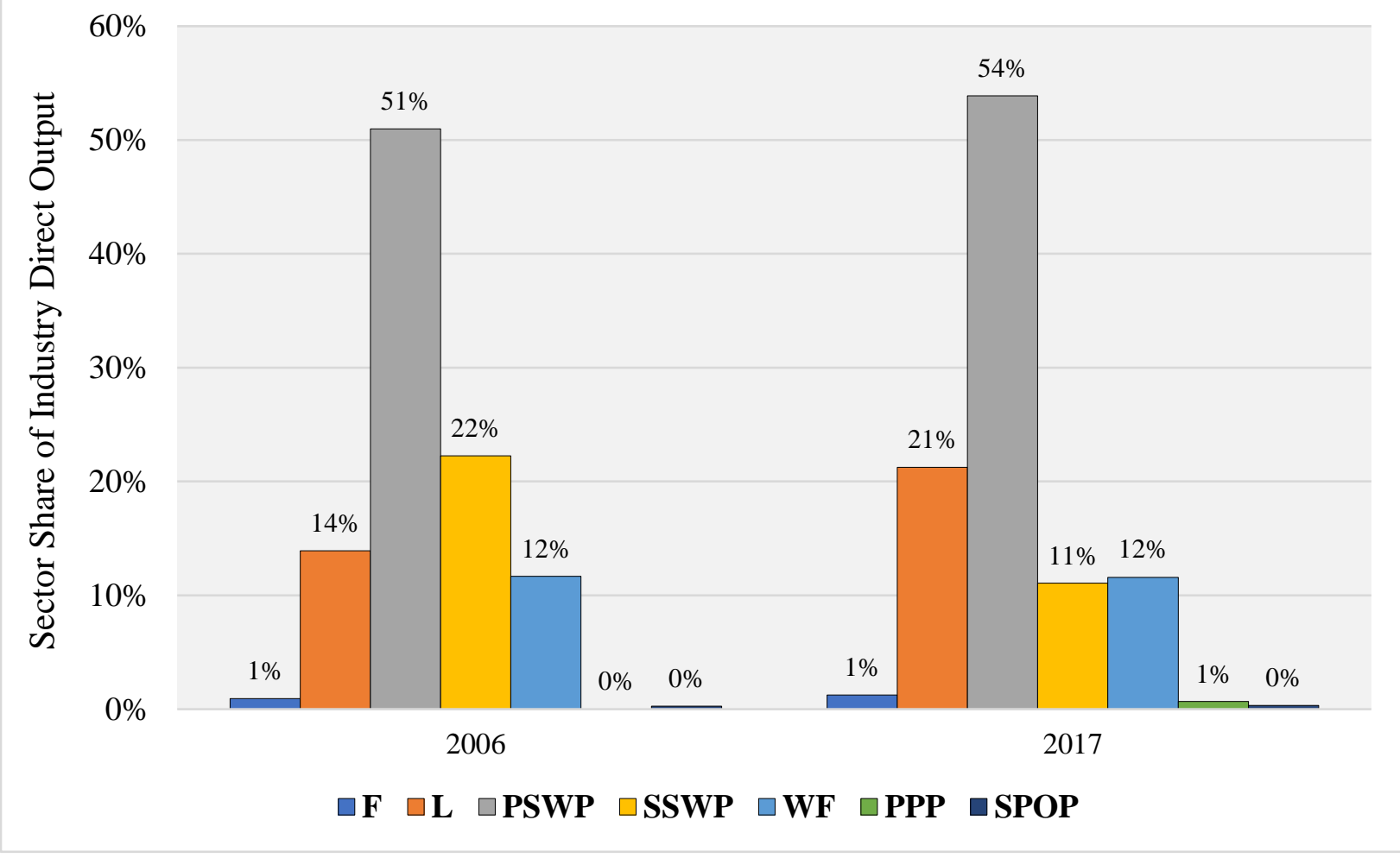

From 2006 to 2017, the largest percentage decreases in direct contributions were found in the secondary solid wood products sector. Each measure of direct contribution of the sector fell by no less than 56 percent over this period and were the largest absolute losses in terms of output and employment. The primary solid wood products sector was more resilient in terms of direct output and employment, however, the sector experienced severe decreases of 44.8 percent and 42.3 percent of direct contributions of value added and employee compensation, respectively, which resulted in the largest absolute decreases of those measures of any sector. Similar to the statewide sector, the region's logging sector experienced decreases in direct employment and employee compensation, though grew in terms of output and value added. The region's wood furniture sector fared somewhat better than the industry as a whole in terms of direct employment and employee compensation which still decreased by 11.9 percent and 16.9 percent, 
respectively. The forestry sector in the region grew immensely over this period, as it was the only sector to see growth in direct contributions of all measures and, in 2017, accounted for 8.2 percent of the region's direct FPI employment. Pulp, paper, and paperboard activity appeared in the region in 2017, which had not existed in 2006, and the secondary paperboard and other paper products sector fared better than the industry overall. However, these sectors each accounted for less than 1 percent of all measures of industry direct contributions in the region in 2017 . These changes show a regional industry that, largely, fared better than the state overall, and better than most other regions in the state. The region's increasing concentration in the logging and primary solid wood products sectors can serve as a foundation for growth in the industry in a region which badly needs the added economic activity. 
Table 30. Contributions of the Region 5 FPI major sectors and associated SAM multipliers for the year 2017. Dollar amounts reported in 2017 dollars.

\begin{tabular}{|c|c|c|c|c|c|c|c|c|c|c|c|c|c|c|}
\hline \multirow{2}{*}{ Contribution Type } & \multicolumn{2}{|c|}{$\mathbf{F}$} & \multicolumn{2}{|c|}{$\mathbf{L}$} & \multicolumn{2}{|c|}{ PSWP } & \multicolumn{2}{|c|}{ SSWP } & \multicolumn{2}{|c|}{ WF } & \multicolumn{2}{|c|}{ PPP } & \multicolumn{2}{|c|}{ SPOP } \\
\hline & 2006 & 2017 & 2006 & 2017 & 2006 & 2017 & 2006 & 2017 & 2006 & 2017 & 2006 & 2017 & 2006 & 2017 \\
\hline Direct & & & & & & & & & & & & & & \\
\hline Output (\$MM) & 3.4 & 3.9 & 50.7 & 67.5 & 185.8 & 171.4 & 81.0 & 35.2 & 42.5 & 36.9 & - & 2.1 & 0.9 & 1.0 \\
\hline Employment & 75 & 127 & 476 & 372 & 672 & 556 & 477 & 184 & 346 & 304 & - & 3 & 3 & 2 \\
\hline Value Added (\$MM) & 2.1 & 3.3 & 26.8 & 59.3 & 53.0 & 29.3 & 26.1 & 10.4 & 17.7 & 9.2 & - & 0.3 & 0.2 & 0.1 \\
\hline Employee Comp. (\$MM) & 0.9 & 3.2 & 13.9 & 8.0 & 35.9 & 20.7 & 18.8 & 8.0 & 14.6 & 12.2 & - & - & 0.2 & 0.1 \\
\hline Indirect & & & & & & & & & & & & & & \\
\hline Output (\$MM) & 0.3 & 0.3 & 9.0 & 2.9 & 70.9 & 93.1 & 21.7 & 13.7 & 7.4 & 11.2 & - & 1.0 & 0.1 & 0.3 \\
\hline Employment & 2 & 5 & 84 & 44 & 500 & 527 & 138 & 79 & 50 & 72 & - & 5 & 1 & 2 \\
\hline Value Added (\$MM) & 0.1 & 0.2 & 4.0 & 1.8 & 33.3 & 56.6 & 9.7 & 7.1 & 3.6 & 5.9 & - & 0.6 & 0.1 & 0.1 \\
\hline Employee Comp. (\$MM) & 0.05 & 0.15 & 1.7 & 1.1 & 18.5 & 21.9 & 5.8 & 3.6 & 2.0 & 3.1 & - & 0.3 & 0.0 & 0.1 \\
\hline Induced & & & & & & & & & & & & & & \\
\hline Output (\$MM) & 0.8 & 2.6 & 9.3 & 17.5 & 23.0 & 35.3 & 10.4 & 8.7 & 6.9 & 10.3 & - & 0.4 & 0.1 & 0.1 \\
\hline Employment & 6 & 20 & 65 & 138 & 159 & 278 & 72 & 69 & 48 & 81 & - & 3 & 0 & 1 \\
\hline Value Added (\$MM) & 0.5 & 1.5 & 5.3 & 10.3 & 13.0 & 20.8 & 5.8 & 5.1 & 3.9 & 6.1 & - & 0.2 & 0.0 & 0.1 \\
\hline Employee Comp. (\$MM) & 0.2 & 0.8 & 2.2 & 5.2 & 5.6 & 10.5 & 2.5 & 2.6 & 1.7 & 3.1 & - & 0.1 & 0.0 & 0.0 \\
\hline Total & & & & & & & & & & & & & & \\
\hline Output (\$MM) & 4.5 & 6.8 & 68.9 & 88.0 & 268.1 & 290.3 & 112.5 & 57.5 & 56.7 & 58.3 & - & 3.5 & 1.1 & 1.4 \\
\hline Employment & 83 & 148 & 624 & 555 & 1,282 & 1,325 & 684 & 331 & 443 & 458 & - & 11 & 3 & 5 \\
\hline Value Added (\$MM) & 2.7 & 4.9 & 36.1 & 71.5 & 96.3 & 105.2 & 41.4 & 22.6 & 25.1 & 21.3 & - & 1.1 & 0.2 & 0.4 \\
\hline Employee Comp. (\$MM) & 1.2 & 4.0 & 17.8 & 14.3 & 57.8 & 51.9 & 27.0 & 14.1 & 18.3 & 18.3 & - & 0.4 & 0.2 & 0.2 \\
\hline SAM Multiplier & & & & & & & & & & & & & & \\
\hline Output (\$MM) & 1.32 & 1.71 & 1.36 & 1.30 & 1.44 & 1.69 & 1.39 & 1.63 & 1.33 & 1.58 & - & 1.68 & 1.18 & 1.40 \\
\hline Employment & 1.10 & 1.17 & 1.31 & 1.49 & 1.91 & 2.38 & 1.43 & 1.80 & 1.28 & 1.50 & - & 3.90 & 1.13 & 2.15 \\
\hline Value Added (\$MM) & 1.29 & 1.50 & 1.34 & 1.20 & 1.82 & 3.59 & 1.59 & 2.17 & 1.42 & 2.30 & - & 4.09 & 1.46 & 2.56 \\
\hline Employee Comp. (\$MM) & 1.26 & 1.26 & 1.28 & 1.78 & 1.61 & 2.50 & 1.44 & 1.77 & 1.25 & 1.50 & - & - & 1.21 & 2.05 \\
\hline
\end{tabular}




\section{CHAPTER V: CONCLUSIONS \& RECOMMENDATIONS}

The West Virginia FPI has undergone significant changes since the last assessment of the industry's economic contribution in 2005. Due to the continuing pressures of global competition, increasing automation, and the immense repercussions of the recession of the mid-to-late 2000s, the same could be said for many industries in the state. In order to gain insight into how the FPI has weathered this turbulent economic period, a new assessment was needed, not just of the industry as it currently exists, but of the historical performance of the industry. To accomplish this, the state's FPI and its major component sectors were examined using the most highly recommended methods for conducting economic contribution analysis with the latest data available. This methodology was then applied consistently to previous years. In the examination of the changes in the industry's economic contributions to the state as a whole, and the separate regions within the state, a comprehensive analysis of the industry's contribution to the state has been presented.

In 2017, the FPI was found to be a significant industry to the state's economy directly contributing 1.1 percent of all employment and 1.0 percent of gross state product. Furthermore, FPI activity supported 2.2 percent of all employment and 1.8 percent of gross state product in the broader state economy through its total contributions. From 2010 to 2015 and from 2015 to 2017, the industry's share of the state's employment and gross state product increased, indicating the industry has outperformed the overall state economy over those years. The jobs, revenue, and employee compensation that the industry provides to the state are crucial to the state and its residents. However, the overall changes in the economic contributions of West Virginia's FPI from 2006 to 2017 reflect an industry that, largely, failed to return to the levels of total 
contributions the industry provided to the state in 2006. Certainly, in terms of total sales, jobs, and employee pay and benefits, the industry supported less in the state economy in 2017 than it did in 2006. However, in terms of valued added, or contribution to gross state product, the industry did show improvement over 2006 levels. Though, closer examination of the data has shown that these gains arose as a result of increases of induced contributions, and, to a lesser extent, indirect contributions that were spurred by the industry, but took place in the broader economy. This growth in non-direct industry contributions relative to direct contributions was reflected by growth in multiplier values and was a common thread found across the years, sectors, regions, and measures of contribution analyzed. This trend illustrates that, although direct industry economic activity had declined, the inter-industry activity and spending of personal income by workers and proprietors that arose due to the industry's operations increased within the state. While the added activity in the broader economy is, of course, beneficial to the state, it is important not to lose sight of the fact that the underlying direct contributions of the FPI in 2017 were still well below those experienced in 2006. The failure of the industry to return to 2006 levels of economic contribution is partially reflective of the fact that the demand for products used in housing construction was over-inflated in 2006, which came to a halt with the collapse of the housing market. However, it also suggests that longer-term pressures on the industry continue to negatively affect industry economic contribution. The offshoring of valueadded hardwood industries, paired with the continued increase in automation, have continued to produce disruptions for the Eastern US hardwood industry over the past two decades (Luppold and Bumgardner, 2017). In addition to these longer-term trends, new challenges have emerged such as the uncertainty many forest products firms face about the future accessibility to the foreign markets upon which they have been increasingly dependent. Additionally, state-specific 
challenges such as poor human capital outcomes and competition for resources from emerging industries like those related to the Marcellus Shale natural gas boom are also likely cause for lack of growth in the industry's direct economic contributions in the state. However, the growth of the industry's non-direct support of the broader state economy, relative to the size of the industry itself, is something that should be leveraged. This growth, which is represented by the industry's increasing multiplier values, should be viewed as an opportunity as any growth in the industry would not only benefit FPI businesses and their workers, but would also benefit the broader state economy. The multiplier values that were found for the industry reflect a large potential economic advantage over other industries such as tourism and outdoor recreation. The ability of the FPI to not only co-exist with these industries, but to complement them is a key advantage of the industry. Those policymakers, economic development officials, entrepreneurs, and others who are searching for potential sources of economic growth in the state would do well to consider the state's abundant forest resources.

In the assessment of the individual sectors of the statewide FPI, it was shown that the two sectors most closely tied to the housing market, the secondary solid wood products and wood furniture sectors, experienced the largest relative decreases in direct contributions from 2006 to 2010. Despite a partial recovery in the sectors from 2010 to 2015, by 2017 the largest percentage decreases in direct contribution from 2006 levels were found in these sectors. It should be noted that, preceding the housing market collapse of the mid-2000s, the wood furniture sector had already been in decline since the late 1990s (Luppold and Bumgardner, 2017). Therefore, those losses in the sector previous to 2006 were not captured by this analysis. Although the primary solid wood products sector also experienced immense decreases in direct 
contributions between 2006 and 2017, it was found to be somewhat more resilient and, as of 2017, was the largest source of direct contributions of the industry by all measures analyzed. The industry's transition away from the more value-added sectors of the industry and into primary solid wood products may be illustrative of the industry becoming more reliant on exporting its forest resources to be used in value-added processes outside of the state. In order for the state to realize the full economic potential of its forest resources, an effort must be made to cultivate and grow new and existing activity within the secondary solid wood products and wood furniture sectors. These sectors not only produce large numbers of relatively high paying jobs as compared to other FPI sectors, but they also provide in-state demand for the state's primary forest resources. The pulp and paper related sectors, which have traditionally not been a feature of the industry in the state, although small, were reflective of the industry as a whole between 2006 and 2017. These sectors experienced substantial decreases in direct contributions and partially offsetting increases in indirect and induced contributions, resulting in mixed changes in total economic contributions of the sectors. It can be noted here as well that the primary pulp, paper, and paperboard sector fared somewhat better than the more value-added sector of secondary paperboard and other paper products. A combination of increases and decreases in separate measures of direct contributions made it difficult to identify trends in the logging and forestry sectors in the state over this period. While logging sector output and value added have made significant gains since 2006, employment and employee compensation suffered substantial losses. It has been shown that a potential cause for the downturn in logging employment in the state may be the emergence of the natural gas industry's demands for labor due to Marcellus Shale exploration (Grushecky and Wang, 2013). Another cause may come in the form of 
increasing worker compensation costs which has put downward pressure on logging employment (Castro, 2018).

The regional analysis of the state identified differences in the changes the industry has undergone in the separate regions of the state from 2006 to 2017. The relative successes of the Highlands and Southern regions' forest products industries from 2006 to 2017 are crucial to note, as these regions are in the most desperate need of economic diversity. While economic development efforts in other regions of the state are largely concentrated in attracting downstream natural gas activities, the focus in the Southern and Highlands region have centered around tourism and retaining as much of the state's diminishing coal industry as possible. The Highlands region was found to serve as the state's forest products hub and bolstered much of the statewide industry's direct contributions from 2006 to 2017 . In 2006, the region was the source of over 50 percent of both the secondary solid wood products and logging sectors' direct contributions in the state, and by 2017 it was also the source of over 50 percent of all primary solid wood products sector direct contributions in the state. As an increasingly important piece of the statewide industry, efforts should be made in the region to induce further FPI activity. The Southern region was the only other region besides the Highlands region to witness industry total contributions of sales and gross regional product increase from 2006 to 2017. This region has faced severe economic hardships in recent decades, as its economy is closely tied to the coal industry. As coal production in the region is unlikely to return to previous levels, it is becoming increasingly important for the region to attract new economic activity in order to diversify its economy. During this economic transition, the region is likely to attract federal funds that could then be administered by the state and regional governments in order to induce economic growth. 
Policymakers and economic development personnel should recognize the relative health of the FPI in the region and consider the industry a potentially smart investment. The ability of the region's FPI to avoid some of the more severe decreases experienced in other regions in the state suggests the industry may be able to provide much-needed economic stability to the region. While the forest products industries in the other regions of the state were found to have fared somewhat worse than the Southern and Highlands region, there were instances of the regional industries bucking the trends found in the statewide industry. The decreases in the secondary solid wood products sector that were experienced in the statewide industry were found in all regions except the Eastern Panhandle region. Likewise, the North Central region was the only region in the state to grow its wood furniture sector. The Ohio River region, the smallest regional industry analyzed, was the only region able to grow its pulp, paper and paperboard sector and, as of 2017, was the only region to have a substantial secondary paperboard and other paper products sector. These exceptions are notable because, in these cases, the regions were able to sustain or grow forest product sectors that were, in all other regions of the state, in decline. While economic development efforts in these regions in the near future are not likely to be targeted at forest products sectors, efforts should be made in the regions to retain these sectors, as the regions have proven to have the resources such as transportation infrastructure, business development resources, access to capital, and workforce needed for the sectors to succeed. The diversity among the regions of West Virginia is an immense resource for the state and the continued existence of these sectors will provide diversity and resilience to the broader statewide FPI into the future. 
In order to grow West Virginia's FPI, concerted efforts must be made by the state's policymakers, economic development authorities, industry advocates, and entrepreneurs. The results of this research suggest that the Southern and Highlands regions of the state are most primed for growth in their forest products industries and should be the primary targets of these efforts. Not only did these regions' forest products industries fare relatively better than those of the rest of the state over the study period, they also are the regions in most desperate need of new economic activity. The FPI in these regions present an immense opportunity to diversify their economies, provide badly-needed jobs, and would serve as a strong foundation upon which to build broader forest products activity in the state. Within these regions, efforts should also be centered around the value-added sectors of the industry, particularly the secondary solid wood products and wood furniture sectors. The losses of these sectors in the state not only affect those firms and workers of the particular sectors but are felt throughout the industry through the loss of potential intrastate activity that could be occurring among the individual forest products sectors. The increasing reliance of the industry on exporting the state's forest resources for value-added processing outside of the state is a major leakage of potential economic activity. Investments made to induce growth in the value-added wood product manufacturing sectors of the industry would produce a greater return through the broader industry-wide activity that would be spurred. These efforts must first be made by economic development authorities within the regions themselves. They must work alongside industry groups and business leaders to identify the needs of the firms that currently exist, and the needs of entrepreneurs attempting to start new forest products businesses in those regions. Once these needs are identified, coordinated efforts must be made by regional and state officials and policymakers. Direct business assistance through general business support, financing, tax incentives, or state procurement programs that directly 
support state businesses are potential tools to be used to promote growth of the industry. Workforce training and placement intermediaries are also vital to provide a skilled labor base for the industry. Finally, the state's forest resources must be promoted to the broader public through educational outreach and marketed as a renewable and abundant resource for the state. As the transition away from carbon-based energy production continues into the future, forest resources should be front and center in any consideration of a large "green" infrastructure program. Specifically, growth in the Southern region's FPI could serve to alleviate the economic hardships of the transition in a region that will be one of the most harshly affected. Wood technologies such as cross laminated timber use in energy efficient residential and commercial buildings and wood-based biomass energy are just two examples of possible targets for development by such a program. Continued research into the economic contribution of the state's FPI is also needed in order to track industry performance and the effectiveness of these efforts. These analyses are crucial as industry professionals and policymakers should not rely on anecdotal or incomplete information about the health of the industry. The state would be well-served to continue efforts to measure the economic contributions of the industry as new data becomes available and methodological advances are made. In doing so, the state's FPI can only be better served by the state's forestry interests through more well-informed decision making. 


\section{APPENDIX}

Appendix A. West Virginia State Forest Products Industry Economic Contribution for years 2006, 2010, 2015, and 2017.

\begin{tabular}{|c|c|c|c|c|c|c|c|c|c|}
\hline \multicolumn{3}{|c|}{ West Virginia } & \multicolumn{2}{|r|}{ Output } & \multirow{2}{*}{$\frac{\text { Employment }}{15,018}$} & \multicolumn{2}{|c|}{ Value Added } & \multicolumn{2}{|c|}{$\begin{array}{c}\text { Employee } \\
\text { Compensation }\end{array}$} \\
\hline \multirow{20}{*}{$\begin{array}{c}\text { Forest } \\
\text { Products } \\
\text { Industry }\end{array}$} & \multirow{5}{*}{2006} & Direct & $\$$ & $2,799,967,217$ & & $\$$ & $897,751,838$ & $\$$ & $621,522,302$ \\
\hline & & Indirect & $\$$ & $862,446,920$ & 5,632 & $\$$ & $361,413,287$ & $\$$ & $192,945,481$ \\
\hline & & Induced & $\$$ & $411,787,576$ & 3,030 & $\$$ & $231,538,523$ & $\$$ & $106,270,585$ \\
\hline & & Total & $\$$ & $3,654,473,707$ & 20,745 & $\$$ & $1,330,064,782$ & $\$$ & $836,673,679$ \\
\hline & & SAM Multiplier & & 1.31 & 1.38 & & 1.48 & & 1.35 \\
\hline & \multirow{5}{*}{2010} & Direct & $\$$ & $1,788,770,514$ & 9,681 & $\$$ & $521,762,591$ & $\$$ & $395,127,996$ \\
\hline & & Indirect & $\$$ & $660,440,821$ & 5,059 & $\$$ & $307,863,288$ & $\$$ & $164,906,428$ \\
\hline & & Induced & $\$$ & $427,383,173$ & 3,547 & $\$$ & $257,441,725$ & $\$$ & $128,927,933$ \\
\hline & & Total & $\$$ & $2,644,013,370$ & 16,608 & $\$$ & $999,897,300$ & $\$$ & $640,850,667$ \\
\hline & & SAM Multiplier & & 1.48 & 1.72 & & 1.92 & & 1.62 \\
\hline & \multirow{5}{*}{2015} & Direct & $\$$ & $2,122,769,342$ & 10,175 & $\$$ & $554,569,397$ & $\$$ & $389,304,152$ \\
\hline & & Indirect & $\$$ & $824,812,112$ & 6,074 & $\$$ & $371,077,081$ & $\$$ & $204,668,822$ \\
\hline & & Induced & $\$$ & $562,094,972$ & 4,797 & $\$$ & $331,494,233$ & $\$$ & $173,316,619$ \\
\hline & & Total & $\$$ & $3,241,902,339$ & 19,029 & $\$$ & $1,166,223,601$ & $\$$ & $715,979,215$ \\
\hline & & SAM Multiplier & & 1.53 & 1.87 & & 2.10 & & 1.84 \\
\hline & \multirow{5}{*}{2017} & Direct & $\$$ & $2,218,669,819$ & 10,198 & $\$$ & $750,464,767$ & $\$$ & $404,549,420$ \\
\hline & & Indirect & $\$$ & $856,867,562$ & 5,025 & $\$$ & $460,000,842$ & $\$$ & $197,579,740$ \\
\hline & & Induced & $\$$ & $638,237,137$ & 5,447 & $\$$ & $382,031,713$ & $\$$ & $203,109,174$ \\
\hline & & Total & & $3,406,759,133$ & 19,219 & $\$$ & $1,429,888,912$ & $\$$ & $764,370,245$ \\
\hline & & SAM Multiplier & & 1.54 & 1.88 & & 1.91 & & 1.89 \\
\hline
\end{tabular}




\begin{tabular}{|c|c|c|c|c|c|c|c|c|c|}
\hline \multicolumn{3}{|c|}{ West Virginia } & \multicolumn{2}{|r|}{ Output } & \multirow{2}{*}{$\begin{array}{r}\text { Employment } \\
551\end{array}$} & \multicolumn{2}{|c|}{ Value Added } & \multicolumn{2}{|c|}{$\begin{array}{c}\text { Employee } \\
\text { Compensation }\end{array}$} \\
\hline \multirow{20}{*}{ Forestry } & \multirow{5}{*}{2006} & Direct & $\$$ & $30,156,744$ & & $\$$ & $19,260,227$ & $\$$ & $8,316,402$ \\
\hline & & Indirect & $\$$ & $2,906,760$ & 29 & $\$$ & $1,442,986$ & $\$$ & 496,810 \\
\hline & & Induced & $\$$ & $8,795,580$ & 64 & $\$$ & $4,916,176$ & $\$$ & $2,222,275$ \\
\hline & & Total & $\$$ & $41,431,133$ & 636 & $\$$ & $25,339,294$ & $\$$ & $10,913,221$ \\
\hline & & SAM Multiplier & & 1.37 & 1.15 & & 1.32 & & 1.31 \\
\hline & \multirow{5}{*}{2010} & Direct & $\$$ & $25,154,815$ & 534 & $\$$ & $17,208,210$ & $\$$ & $6,582,514$ \\
\hline & & Indirect & $\$$ & $2,706,014$ & 32 & $\$$ & $1,546,167$ & $\$$ & 675,644 \\
\hline & & Induced & $\$$ & $9,319,447$ & 77 & $\$$ & $5,607,554$ & $\$$ & $2,800,106$ \\
\hline & & Total & $\$$ & $36,562,791$ & 628 & $\$$ & $23,918,157$ & $\$$ & $9,926,200$ \\
\hline & & SAM Multiplier & & 1.45 & 1.18 & & 1.39 & & 1.51 \\
\hline & \multirow{5}{*}{2015} & Direct & $\$$ & $24,827,023$ & 497 & $\$$ & $17,517,882$ & $\$$ & $4,483,213$ \\
\hline & & Indirect & $\$$ & $2,494,249$ & 24 & $\$$ & $1,246,878$ & $\$$ & 596,794 \\
\hline & & Induced & $\$$ & $9,681,331$ & 83 & $\$$ & $5,712,187$ & $\$$ & $2,979,801$ \\
\hline & & Total & $\$$ & $36,676,762$ & 596 & $\$$ & $24,228,349$ & $\$$ & $7,996,163$ \\
\hline & & SAM Multiplier & & 1.48 & 1.20 & & 1.38 & & 1.78 \\
\hline & \multirow{5}{*}{2017} & Direct & $\$$ & $26,350,462$ & 792 & $\$$ & $22,729,836$ & $\$$ & $17,608,202$ \\
\hline & & Indirect & $\$$ & $1,751,881$ & 19 & $\$$ & 956,516 & $\$$ & 539,953 \\
\hline & & Induced & $\$$ & $20,868,169$ & 176 & $\$$ & $12,341,673$ & $\$$ & $6,449,446$ \\
\hline & & Total & $\$$ & $48,696,610$ & 977 & $\$$ & $35,788,742$ & $\$$ & $24,394,102$ \\
\hline & & SAM Multiplier & & 1.85 & 1.23 & & 1.57 & & 1.39 \\
\hline \multicolumn{3}{|c|}{ West Virginia } & \multicolumn{2}{|r|}{ Output } & Employment & \multicolumn{2}{|c|}{ Value Added } & \multicolumn{2}{|c|}{$\begin{array}{c}\text { Employee } \\
\text { Compensation }\end{array}$} \\
\hline \multirow{20}{*}{ Logging } & \multirow{5}{*}{2006} & Direct & $\$$ & $248,695,005$ & 2,419 & $\$$ & $126,867,043$ & $\$$ & $49,683,280$ \\
\hline & & Indirect & $\$$ & $50,028,527$ & 647 & $\$$ & $21,682,809$ & $\$$ & $9,269,958$ \\
\hline & & Induced & $\$$ & $60,949,147$ & 454 & $\$$ & $34,475,225$ & $\$$ & $15,994,804$ \\
\hline & & Total & $\$$ & $358,832,531$ & 3,173 & $\$$ & $182,668,344$ & $\$$ & $74,808,341$ \\
\hline & & SAM Multiplier & & 1.44 & 1.31 & & 1.44 & & 1.51 \\
\hline & \multirow{5}{*}{2010} & Direct & $\$$ & $143,064,926$ & 1,493 & $\$$ & $81,066,622$ & $\$$ & $32,222,021$ \\
\hline & & Indirect & $\$$ & $40,716,754$ & 1,161 & $\$$ & $21,231,970$ & $\$$ & $9,352,891$ \\
\hline & & Induced & $\$$ & $65,819,205$ & 548 & $\$$ & $39,630,500$ & $\$$ & $19,810,690$ \\
\hline & & Total & $\$$ & $249,316,864$ & 3,200 & $\$$ & $141,748,807$ & $\$$ & $61,313,942$ \\
\hline & & SAM Multiplier & & 1.74 & 2.14 & & 1.75 & & 1.90 \\
\hline & \multirow{5}{*}{2015} & Direct & $\$$ & $145,287,055$ & 1,940 & $\$$ & $80,701,483$ & $\$$ & $39,065,119$ \\
\hline & & Indirect & $\$$ & $35,506,508$ & 947 & $\$$ & $16,700,144$ & $\$$ & $7,307,301$ \\
\hline & & Induced & $\$$ & $74,781,562$ & 636 & $\$$ & $43,968,490$ & $\$$ & $22,814,684$ \\
\hline & & Total & $\$$ & $255,362,270$ & 3,521 & $\$$ & $141,240,892$ & $\$$ & $69,124,548$ \\
\hline & & SAM Multiplier & & 1.76 & 1.81 & & 1.75 & & 1.77 \\
\hline & \multirow{5}{*}{2017} & Direct & $\$$ & $354,326,691$ & 1,919 & $\$$ & $312,182,430$ & $\$$ & $36,309,479$ \\
\hline & & Indirect & $\$$ & $19,285,590$ & 453 & $\$$ & $10,838,512$ & $\$$ & $5,481,937$ \\
\hline & & Induced & $\$$ & $138,113,873$ & 1,173 & $\$$ & $82,291,431$ & $\$$ & $43,323,954$ \\
\hline & & Total & $\$$ & $511,545,210$ & 3,544 & $\$$ & $405,152,947$ & $\$$ & $85,096,827$ \\
\hline & & SAM Multiplier & & 1.44 & 1.85 & & 1.30 & & 2.34 \\
\hline
\end{tabular}




\begin{tabular}{|c|c|c|c|c|c|c|c|c|c|}
\hline \multicolumn{3}{|c|}{ West Virginia } & \multicolumn{2}{|r|}{ Output } & \multirow{2}{*}{$\begin{array}{r}\text { Employment } \\
4,252\end{array}$} & \multicolumn{2}{|c|}{ Value Added } & \multicolumn{2}{|c|}{$\begin{array}{c}\text { Employee } \\
\text { Compensation }\end{array}$} \\
\hline \multirow{20}{*}{$\begin{array}{c}\text { Primary } \\
\text { Solid Wood } \\
\text { Products }\end{array}$} & \multirow{5}{*}{2006} & Direct & 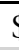 & $1,037,780,138$ & & $\$$ & $285,634,757$ & $\$$ & $209,269,745$ \\
\hline & & Indirect & $\$$ & $479,663,327$ & 3,357 & $\$$ & $207,286,909$ & $\$$ & $103,701,207$ \\
\hline & & Induced & 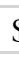 & $175,173,107$ & 1,296 & $\$$ & $98,821,934$ & $\$$ & $45,672,284$ \\
\hline & & Total & s & $1,597,012,438$ & 8,493 & $\$$ & $566,471,748$ & $\$$ & $340,067,277$ \\
\hline & & SAM Multiplier & & 1.54 & 2.00 & & 1.98 & & 1.63 \\
\hline & \multirow{5}{*}{2010} & Direct & $\$$ & $747,859,229$ & 2,990 & $\$$ & $166,944,479$ & $\$$ & $140,227,407$ \\
\hline & & Indirect & $s$ & $365,191,908$ & 2,905 & $\$$ & $174,081,892$ & $\$$ & $89,798,786$ \\
\hline & & Induced & 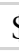 & $189,305,807$ & 1,577 & $\$$ & $114,333,314$ & $\$$ & $57,555,245$ \\
\hline & & Total & 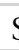 & $1,239,205,850$ & 7,202 & $\$$ & $441,757,052$ & $\$$ & $276,154,619$ \\
\hline & & SAM Multiplier & & 1.66 & 2.41 & & 2.65 & & 1.97 \\
\hline & \multirow{5}{*}{2015} & Direct & s & $909,964,718$ & 3,006 & $\$$ & $181,411,212$ & $\$$ & $130,907,703$ \\
\hline & & Indirect & 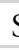 & $459,901,007$ & 3,645 & $\$$ & $212,037,781$ & $\$$ & $114,715,201$ \\
\hline & & Induced & & $253,773,791$ & 2,173 & $\$$ & $150,082,097$ & $\$$ & $78,797,062$ \\
\hline & & Total & & $1,545,937,292$ & 8,542 & $\$$ & $529,093,113$ & $\$$ & $313,396,720$ \\
\hline & & SAM Multiplier & & 1.70 & 2.84 & & 2.92 & & 2.39 \\
\hline & \multirow{5}{*}{2017} & Direct & s & $878,920,059$ & 2,836 & $\$$ & $171,284,294$ & $\$$ & $132,275,242$ \\
\hline & & Indirect & s & $494,223,271$ & 2,776 & $\$$ & $285,654,387$ & $\$$ & $106,380,786$ \\
\hline & & Induced & $\$$ & $263,230,480$ & 2,257 & $\$$ & $158,206,457$ & $\$$ & $84,575,822$ \\
\hline & & Total & & $1,561,150,928$ & 7,598 & $\$$ & $601,335,996$ & $\$$ & $311,901,259$ \\
\hline & & SAM Multiplier & & 1.78 & 2.68 & & 3.51 & & 2.36 \\
\hline
\end{tabular}

\begin{tabular}{|c|c|c|c|c|c|c|c|c|c|}
\hline \multicolumn{3}{|c|}{ West Virginia } & \multicolumn{2}{|r|}{ Output } & \multirow{2}{*}{$\frac{\text { Employment }}{4,792}$} & \multicolumn{2}{|c|}{ Value Added } & \multicolumn{2}{|c|}{$\begin{array}{c}\text { Employee } \\
\text { Compensation }\end{array}$} \\
\hline \multirow{20}{*}{$\begin{array}{c}\text { Secondary } \\
\text { Solid Wood } \\
\text { Products }\end{array}$} & \multirow{5}{*}{2006} & Direct & $\$$ & $853,125,517$ & & $\$$ & $292,300,229$ & $\$$ & $213,610,448$ \\
\hline & & Indirect & $\$$ & $290,181,777$ & 1,763 & $\$$ & $116,892,097$ & $\$$ & $68,187,151$ \\
\hline & & Induced & $\$$ & $146,720,043$ & 1,075 & $\$$ & $82,271,404$ & $\$$ & $37,547,817$ \\
\hline & & Total & $\$$ & $1,274,512,326$ & 7,544 & $\$$ & $486,220,519$ & $\$$ & $315,928,460$ \\
\hline & & SAM Multiplier & & 1.49 & 1.57 & & 1.66 & & 1.48 \\
\hline & \multirow{5}{*}{2010} & Direct & $\$$ & $436,110,524$ & 2,721 & $\$$ & $140,201,961$ & $\$$ & $120,535,278$ \\
\hline & & Indirect & $\$$ & $177,365,145$ & 1,181 & $\$$ & $78,615,853$ & $\$$ & $45,451,155$ \\
\hline & & Induced & $\$$ & $125,854,111$ & 1,040 & $\$$ & $75,590,206$ & $\$$ & $37,643,422$ \\
\hline & & Total & $\$$ & $734,479,956$ & 4,912 & $\$$ & $292,860,852$ & $\$$ & $202,400,582$ \\
\hline & & SAM Multiplier & & 1.68 & 1.81 & & 2.09 & & 1.68 \\
\hline & \multirow{5}{*}{2015} & Direct & $\$$ & $548,057,227$ & 2,747 & $\$$ & $169,809,705$ & $\$$ & $120,924,258$ \\
\hline & & Indirect & $\$$ & $227,613,756$ & 1,459 & $\$$ & $97,053,619$ & $\$$ & $56,067,141$ \\
\hline & & Induced & $\$$ & $170,126,528$ & 1,448 & $\$$ & $100,079,283$ & $\$$ & $52,138,916$ \\
\hline & & Total & $\$$ & $939,083,337$ & 5,621 & $\$$ & $364,813,648$ & $\$$ & $227,778,624$ \\
\hline & & SAM Multiplier & & 1.71 & 2.05 & & 2.15 & & 1.88 \\
\hline & \multirow{5}{*}{2017} & Direct & $\$$ & $512,662,138$ & 2,613 & $\$$ & $152,836,775$ & $\$$ & $120,323,988$ \\
\hline & & Indirect & $\$$ & $231,918,807$ & 1,299 & $\$$ & $111,555,312$ & $\$$ & $55,565,885$ \\
\hline & & Induced & $\$$ & $168,976,892$ & 1,438 & $\$$ & $100,924,380$ & $\$$ & $53,543,658$ \\
\hline & & Total & $\$$ & $907,002,236$ & 5,316 & $\$$ & $363,435,465$ & $\$$ & $228,059,367$ \\
\hline & & SAM Multiplier & & 1.77 & 2.03 & & 2.38 & & 1.90 \\
\hline
\end{tabular}




\begin{tabular}{|c|c|c|c|c|c|c|c|c|c|}
\hline \multicolumn{3}{|c|}{ West Virginia } & \multicolumn{2}{|r|}{ Output } & \multirow{2}{*}{$\begin{array}{r}\text { Employment } \\
2,224\end{array}$} & \multicolumn{2}{|c|}{ Value Added } & \multicolumn{2}{|c|}{$\begin{array}{c}\text { Employee } \\
\text { Compensation }\end{array}$} \\
\hline \multirow{20}{*}{$\begin{array}{l}\text { Wood } \\
\text { Furniture }\end{array}$} & \multirow{5}{*}{2006} & Direct & $\$$ & $271,057,920$ & & $\$$ & $111,992,028$ & $\$$ & $90,106,790$ \\
\hline & & Indirect & $\$$ & $59,020,415$ & 371 & $\$$ & $25,516,181$ & $\$$ & $14,488,954$ \\
\hline & & Induced & $\$$ & $53,214,472$ & 387 & $\$$ & $29,728,029$ & $\$$ & $13,457,450$ \\
\hline & & Total & $\$$ & $383,239,808$ & 2,982 & $\$$ & $167,216,272$ & $\$$ & $118,033,921$ \\
\hline & & SAM Multiplier & & 1.41 & 1.34 & & 1.49 & & 1.31 \\
\hline & \multirow{5}{*}{2010} & Direct & $\$$ & $134,430,879$ & 1,302 & $\$$ & $59,545,155$ & $\$$ & $54,401,969$ \\
\hline & & Indirect & $\$$ & $37,125,996$ & 257 & $\$$ & $17,787,831$ & $\$$ & $9,930,064$ \\
\hline & & Induced & $\$$ & $48,006,106$ & 394 & $\$$ & $28,730,382$ & $\$$ & $14,205,157$ \\
\hline & & Total & $\$$ & $219,542,078$ & 1,953 & $\$$ & $106,017,862$ & $\$$ & $78,494,671$ \\
\hline & & SAM Multiplier & & 1.63 & 1.50 & & 1.78 & & 1.44 \\
\hline & \multirow{5}{*}{2015} & Direct & $\$$ & $166,191,498$ & 1,408 & $\$$ & $48,102,501$ & $\$$ & $55,538,944$ \\
\hline & & Indirect & $\$$ & $51,550,164$ & 336 & $\$$ & $23,475,857$ & $\$$ & $13,387,665$ \\
\hline & & Induced & $\$$ & $62,174,723$ & 525 & $\$$ & $36,360,557$ & $\$$ & $18,767,567$ \\
\hline & & Total & $\$$ & $279,817,249$ & 2,270 & $\$$ & $107,900,259$ & $\$$ & $87,649,977$ \\
\hline & & SAM Multiplier & & 1.68 & 1.61 & & 2.24 & & 1.58 \\
\hline & \multirow{5}{*}{2017} & Direct & $\$$ & $186,334,926$ & 1,527 & $\$$ & $49,522,152$ & $\$$ & $66,181,317$ \\
\hline & & Indirect & $\$$ & $62,533,493$ & 394 & $\$$ & $30,405,453$ & $\$$ & $16,355,901$ \\
\hline & & Induced & $\$$ & $70,867,535$ & 599 & $\$$ & $42,086,717$ & $\$$ & $22,166,510$ \\
\hline & & Total & $\$$ & $319,668,183$ & 2,519 & $\$$ & $121,995,965$ & $\$$ & $104,680,057$ \\
\hline & & SAM Multiplier & & 1.72 & 1.65 & & 2.46 & & 1.58 \\
\hline
\end{tabular}

\begin{tabular}{|c|c|c|c|c|c|c|c|c|c|}
\hline \multicolumn{3}{|c|}{ West Virginia } & \multicolumn{2}{|r|}{ Output } & \multirow{2}{*}{$\frac{\text { Employment }}{337}$} & \multicolumn{2}{|c|}{ Value Added } & \multicolumn{2}{|c|}{$\begin{array}{c}\text { Employee } \\
\text { Compensation }\end{array}$} \\
\hline \multirow{20}{*}{$\begin{array}{c}\text { Pulp, Paper, } \\
\text { and } \\
\text { Paperboard }\end{array}$} & \multirow{5}{*}{2006} & Direct & $\$$ & $228,997,650$ & & $\$$ & $33,259,747$ & $\$$ & $24,822,034$ \\
\hline & & Indirect & $\$$ & $66,392,294$ & 332 & $\$$ & $25,924,910$ & $\$$ & $13,785,844$ \\
\hline & & Induced & $\$$ & $20,314,173$ & 152 & $\$$ & $11,558,097$ & $\$$ & $5,440,217$ \\
\hline & & Total & $\$$ & $314,810,723$ & 753 & $\$$ & $66,026,119$ & $\$$ & $40,438,009$ \\
\hline & & SAM Multiplier & & 1.37 & 2.23 & & 1.99 & & 1.63 \\
\hline & \multirow{5}{*}{2010} & Direct & $\$$ & $209,475,060$ & 300 & $\$$ & $36,078,344$ & $\$$ & $22,718,029$ \\
\hline & & Indirect & $\$$ & $86,377,976$ & 514 & $\$$ & $38,961,031$ & $\$$ & $20,844,774$ \\
\hline & & Induced & $\$$ & $36,963,726$ & 310 & $\$$ & $22,425,829$ & $\$$ & $11,390,594$ \\
\hline & & Total & $\$$ & $332,743,855$ & 1,124 & $\$$ & $97,428,621$ & $\$$ & $54,929,380$ \\
\hline & & SAM Multiplier & & 1.59 & 3.74 & & 2.70 & & 2.42 \\
\hline & \multirow{5}{*}{2015} & Direct & $\$$ & $193,663,195$ & 260 & $\$$ & $30,248,584$ & $\$$ & $19,509,017$ \\
\hline & & Indirect & $\$$ & $91,238,544$ & 527 & $\$$ & $40,064,873$ & $\$$ & $21,647,621$ \\
\hline & & Induced & $\$$ & $44,221,646$ & 381 & $\$$ & $26,288,750$ & $\$$ & $13,920,860$ \\
\hline & & Total & $\$$ & $328,335,361$ & 1,167 & $\$$ & $96,450,239$ & $\$$ & $54,975,367$ \\
\hline & & SAM Multiplier & & 1.70 & 4.49 & & 3.19 & & 2.82 \\
\hline & \multirow{5}{*}{2017} & Direct & $\$$ & $150,747,921$ & 232 & $\$$ & $21,441,537$ & $\$$ & $15,819,519$ \\
\hline & & Indirect & $\$$ & $79,460,496$ & 410 & $\$$ & $40,452,514$ & $\$$ & $19,071,038$ \\
\hline & & Induced & $\$$ & $39,178,455$ & 339 & $\$$ & $23,706,469$ & $\$$ & $12,794,750$ \\
\hline & & Total & $\$$ & $269,168,035$ & 980 & $\$$ & $85,568,300$ & $\$$ & $47,659,712$ \\
\hline & & SAM Multiplier & & 1.79 & 4.23 & & 3.99 & & 3.01 \\
\hline
\end{tabular}




\begin{tabular}{|c|c|c|c|c|c|c|c|c|c|}
\hline \multicolumn{3}{|c|}{ West Virginia } & \multicolumn{2}{|r|}{ Output } & \multirow{2}{*}{$\begin{array}{r}\text { Employment } \\
443\end{array}$} & \multicolumn{2}{|c|}{ Value Added } & \multicolumn{2}{|c|}{$\begin{array}{c}\text { Employee } \\
\text { Compensation }\end{array}$} \\
\hline \multirow{20}{*}{$\begin{array}{c}\text { Secondary } \\
\text { Paperboard } \\
\text { and other } \\
\text { Paper } \\
\text { Products }\end{array}$} & \multirow{5}{*}{2006} & Direct & $\$$ & $130,154,242$ & & $\$$ & $28,437,808$ & $\$$ & $25,713,603$ \\
\hline & & Indirect & $\$$ & $14,911,771$ & 77 & $\$$ & $6,736,700$ & $\$$ & $3,762,254$ \\
\hline & & Induced & $\$$ & $14,363,258$ & 105 & $\$$ & $8,049,453$ & $\$$ & $3,670,116$ \\
\hline & & Total & $\$$ & $159,346,256$ & 625 & $\$$ & $43,211,696$ & $\$$ & $33,134,239$ \\
\hline & & SAM Multiplier & & 1.22 & 1.41 & & 1.52 & & 1.29 \\
\hline & \multirow{5}{*}{2010} & Direct & $\$$ & $92,675,081$ & 339 & $\$$ & $20,717,820$ & $\$$ & $18,440,778$ \\
\hline & & Indirect & $\$$ & $15,710,771$ & 91 & $\$$ & $8,114,895$ & $\$$ & $4,463,528$ \\
\hline & & Induced & $\$$ & $16,612,584$ & 137 & $\$$ & $9,987,062$ & $\$$ & $4,983,337$ \\
\hline & & Total & $\$$ & $124,961,562$ & 568 & $\$$ & $38,797,774$ & $\$$ & $27,867,972$ \\
\hline & & SAM Multiplier & & 1.35 & 1.67 & & 1.87 & & 1.51 \\
\hline & \multirow{5}{*}{2015} & Direct & $\$$ & $134,778,626$ & 315 & $\$$ & $26,778,029$ & $\$$ & $18,875,899$ \\
\hline & & Indirect & $\$$ & $26,126,136$ & 155 & $\$$ & $12,981,746$ & $\$$ & $7,312,818$ \\
\hline & & Induced & $\$$ & $24,908,327$ & 213 & $\$$ & $14,697,974$ & $\$$ & $7,697,177$ \\
\hline & & Total & $\$$ & $185,744,076$ & 683 & $\$$ & $54,428,405$ & $\$$ & $33,864,191$ \\
\hline & & SAM Multiplier & & 1.38 & 2.17 & & 2.03 & & 1.79 \\
\hline & \multirow{5}{*}{2017} & Direct & $\$$ & $109,327,621$ & 281 & $\$$ & $20,467,743$ & $\$$ & $16,031,673$ \\
\hline & & Indirect & $\$$ & $23,440,392$ & 139 & $\$$ & $12,530,011$ & $\$$ & $6,824,269$ \\
\hline & & Induced & $\$$ & $22,092,928$ & 190 & $\$$ & $13,287,792$ & $\$$ & $7,117,916$ \\
\hline & & Total & $\$$ & $154,778,361$ & 609 & $\$$ & $46,271,066$ & $\$$ & $29,962,271$ \\
\hline & & SAM Multiplier & & 1.42 & 2.17 & & 2.26 & & 1.87 \\
\hline
\end{tabular}


Appendix B. West Virginia Forest Products Industry Regional Economic Contribution for years 2006 and 2017.

Region 1 - Ohio River Region: Brooke, Cabell, Hancock, Jackson, Marshall, Mason, Ohio, Pleasants, Putnam, Tyler, Wetzel, and Wood counties

\begin{tabular}{|c|c|c|c|c|c|c|c|c|c|}
\hline \multicolumn{3}{|c|}{ Region 1 - Ohio River Region } & \multicolumn{2}{|r|}{ Output } & \multirow{2}{*}{$\begin{array}{r}\text { Employment } \\
1,714\end{array}$} & \multicolumn{2}{|c|}{ Value Added } & \multicolumn{2}{|c|}{$\begin{array}{c}\text { Employee } \\
\text { Compensation } \\
\end{array}$} \\
\hline \multirow{10}{*}{$\begin{array}{l}\text { Forest } \\
\text { Products } \\
\text { Industry }\end{array}$} & \multirow{5}{*}{2006} & Direct & $\$$ & $318,095,497$ & & $\$$ & $88,073,178$ & $\$$ & $64,976,283$ \\
\hline & & Indirect & $\$$ & $47,318,770$ & 333 & $\$$ & $20,373,991$ & $\$$ & $10,529,134$ \\
\hline & & Induced & $\$$ & $23,824,589$ & 146 & $\$$ & $12,668,157$ & $\$$ & $4,649,687$ \\
\hline & & Total & $\$$ & $378,099,463$ & 2,096 & $\$$ & $117,271,121$ & $\$$ & $78,630,151$ \\
\hline & & SAM Multiplier & & 1.19 & 1.22 & & 1.33 & & 1.21 \\
\hline & \multirow{5}{*}{2017} & Direct & $\$$ & $255,213,915$ & 1,005 & $\$$ & $59,259,397$ & $\$$ & $41,537,312$ \\
\hline & & Indirect & $\$$ & $66,389,346$ & 462 & $\$$ & $36,046,697$ & $\$$ & $17,911,549$ \\
\hline & & Induced & $\$$ & $45,514,136$ & 376 & $\$$ & $26,097,101$ & $\$$ & $13,168,871$ \\
\hline & & Total & $\$$ & $360,434,413$ & 1,776 & $\$$ & $117,576,344$ & $\$$ & $72,021,735$ \\
\hline & & SAM Multiplier & & 1.41 & 1.77 & & 1.98 & & 1.73 \\
\hline
\end{tabular}

\begin{tabular}{|c|c|c|c|c|c|c|c|c|c|}
\hline \multicolumn{3}{|c|}{ Region 1 - Ohio River Region } & \multicolumn{2}{|c|}{ Output } & \multirow{2}{*}{$\begin{array}{r}\text { Employment } \\
70\end{array}$} & \multicolumn{2}{|c|}{ Value Added } & \multicolumn{2}{|c|}{$\begin{array}{c}\text { Employee } \\
\text { Compensation } \\
\end{array}$} \\
\hline \multirow{10}{*}{ Forestry } & \multirow{5}{*}{2006} & Direct & $\$$ & $3,429,731$ & & $\$$ & $1,886,448$ & $\$$ & 494,963 \\
\hline & & Indirect & $\$$ & 318,248 & 5 & $\$$ & 150,079 & $\$$ & 47,665 \\
\hline & & Induced & $\$$ & 529,714 & 3 & $\$$ & 282,109 & $\$$ & 103,232 \\
\hline & & Total & $\$$ & $4,214,597$ & 60 & $\$$ & $2,127,176$ & $\$$ & 594,012 \\
\hline & & SAM Multiplier & & 1.23 & 0.86 & & 1.13 & & 1.20 \\
\hline & \multirow{5}{*}{2017} & Direct & $\$$ & $3,606,358$ & 114 & $\$$ & $3,168,117$ & $\$$ & $2,624,915$ \\
\hline & & Indirect & $\$$ & 115,490 & 1 & $\$$ & 66,390 & $\$$ & 34,673 \\
\hline & & Induced & $\$$ & $2,306,918$ & 19 & $\$$ & $1,323,127$ & $\$$ & 667,166 \\
\hline & & Total & $\$$ & $6,028,607$ & 134 & $\$$ & $4,557,495$ & $\$$ & $3,326,637$ \\
\hline & & SAM Multiplier & & 1.67 & 1.17 & & 1.44 & & 1.27 \\
\hline
\end{tabular}




\begin{tabular}{|c|c|c|c|c|c|c|c|c|c|}
\hline \multicolumn{3}{|c|}{ Region 1 - Ohio River Region } & \multicolumn{2}{|c|}{ Output } & \multirow{2}{*}{$\begin{array}{r}\text { Employment } \\
179\end{array}$} & \multicolumn{2}{|c|}{ Value Added } & \multicolumn{2}{|c|}{$\begin{array}{c}\text { Employee } \\
\text { Compensation }\end{array}$} \\
\hline \multirow{10}{*}{ Logging } & \multirow{5}{*}{2006} & Direct & $\$$ & $16,452,132$ & & $\$$ & $7,346,210$ & $\$$ & $2,046,790$ \\
\hline & & Indirect & $\$$ & $3,205,916$ & 67 & $\$$ & $1,207,994$ & $\$$ & 435,219 \\
\hline & & Induced & $\$$ & $2,182,044$ & 13 & $\$$ & $1,161,910$ & $\$$ & 425,301 \\
\hline & & Total & $\$$ & $21,822,676$ & 259 & $\$$ & $9,712,506$ & $\$$ & $2,906,306$ \\
\hline & & SAM Multiplier & & 1.33 & 1.45 & & 1.32 & & 1.42 \\
\hline & \multirow{5}{*}{2017} & Direct & $\$$ & $13,451,591$ & 164 & $\$$ & $9,838,057$ & $\$$ & 738,378 \\
\hline & & Indirect & $\$$ & $1,366,985$ & 56 & $\$$ & 708,355 & $\$$ & 390,146 \\
\hline & & Induced & $\$$ & $4,405,644$ & 37 & $\$$ & $2,531,045$ & $\$$ & $1,272,356$ \\
\hline & & Total & $\$$ & $19,222,295$ & 257 & $\$$ & $13,076,049$ & $\$$ & $2,400,775$ \\
\hline & & SAM Multiplier & & 1.43 & 1.56 & & 1.33 & & 3.25 \\
\hline
\end{tabular}

\begin{tabular}{|c|c|c|c|c|c|c|c|c|c|}
\hline \multicolumn{3}{|c|}{ Region 1 - Ohio River Region } & \multicolumn{2}{|c|}{ Output } & \multirow{2}{*}{$\begin{array}{r}\text { Employment } \\
94\end{array}$} & \multicolumn{2}{|c|}{ Value Added } & \multicolumn{2}{|c|}{$\begin{array}{c}\text { Employee } \\
\text { Compensation } \\
\end{array}$} \\
\hline \multirow{10}{*}{$\begin{array}{c}\text { Primary } \\
\text { Solid Wood } \\
\text { Products }\end{array}$} & \multirow{5}{*}{2006} & Direct & $\$$ & $19,594,629$ & & $\$$ & $3,554,471$ & $\$$ & $2,462,769$ \\
\hline & & Indirect & $\$$ & $7,984,755$ & 75 & $\$$ & $3,469,097$ & $\$$ & $1,411,724$ \\
\hline & & Induced & $\$$ & $1,553,538$ & 10 & $\$$ & 826,450 & $\$$ & 303,062 \\
\hline & & Total & $\$$ & $28,593,009$ & 176 & $\$$ & $7,753,878$ & $\$$ & $4,110,944$ \\
\hline & & SAM Multiplier & & 1.46 & 1.87 & & 2.18 & & 1.67 \\
\hline & \multirow{5}{*}{2017} & Direct & $\$$ & $22,015,272$ & 81 & $\$$ & $4,106,306$ & $\$$ & $2,664,518$ \\
\hline & & Indirect & $\$$ & $10,082,199$ & 89 & $\$$ & $5,992,244$ & $\$$ & $2,233,751$ \\
\hline & & Induced & $\$$ & $4,792,009$ & 40 & $\$$ & $2,749,136$ & $\$$ & $1,385,753$ \\
\hline & & Total & $\$$ & $36,486,681$ & 208 & $\$$ & $12,772,556$ & $\$$ & $6,235,270$ \\
\hline & & SAM Multiplier & & 1.66 & 2.56 & & 3.11 & & 2.34 \\
\hline
\end{tabular}

\begin{tabular}{|c|c|c|c|c|c|c|c|c|c|}
\hline \multicolumn{3}{|c|}{ Region 1 - Ohio River Region } & \multicolumn{2}{|r|}{ Output } & \multirow{2}{*}{$\begin{array}{r}\text { Employment } \\
616\end{array}$} & \multicolumn{2}{|c|}{ Value Added } & \multicolumn{2}{|c|}{$\begin{array}{c}\text { Employee } \\
\text { Compensation }\end{array}$} \\
\hline \multirow{10}{*}{$\begin{array}{c}\text { Secondary } \\
\text { Solid Wood } \\
\text { Products }\end{array}$} & \multirow{5}{*}{2006} & Direct & $\$$ & $99,396,476$ & & $\$$ & $31,076,741$ & $\$$ & $24,500,149$ \\
\hline & & Indirect & $\$$ & $16,894,167$ & 106 & $\$$ & $7,187,869$ & $\$$ & $4,057,173$ \\
\hline & & Induced & $\$$ & $8,401,025$ & 51 & $\$$ & $4,466,176$ & $\$$ & $1,639,861$ \\
\hline & & Total & $\$$ & $123,724,996$ & 767 & $\$$ & $42,446,960$ & $\$$ & $29,983,169$ \\
\hline & & SAM Multiplier & & 1.24 & 1.25 & & 1.37 & & 1.22 \\
\hline & \multirow{5}{*}{2017} & Direct & $\$$ & $23,029,116$ & 121 & $\$$ & $6,406,060$ & $\$$ & $4,601,353$ \\
\hline & & Indirect & $\$$ & 6,481,463 & 44 & $\$$ & $3,460,065$ & $\$$ & $1,818,639$ \\
\hline & & Induced & $\$$ & $4,857,496$ & 40 & $\$$ & $2,785,110$ & $\$$ & $1,405,487$ \\
\hline & & Total & $\$$ & $34,277,152$ & 204 & $\$$ & $12,624,130$ & $\$$ & $7,806,307$ \\
\hline & & SAM Multiplier & & 1.49 & 1.69 & & 1.97 & & 1.70 \\
\hline
\end{tabular}




\begin{tabular}{|c|c|c|c|c|c|c|c|c|c|}
\hline \multicolumn{3}{|c|}{ Region 1 - Ohio River Region } & \multicolumn{2}{|c|}{ Output } & \multirow{2}{*}{$\begin{array}{r}\text { Employment } \\
382\end{array}$} & \multicolumn{2}{|c|}{ Value Added } & \multicolumn{2}{|c|}{$\begin{array}{c}\text { Employee } \\
\text { Compensation }\end{array}$} \\
\hline \multirow{10}{*}{$\begin{array}{l}\text { Wood } \\
\text { Furniture }\end{array}$} & \multirow{5}{*}{2006} & Direct & $\$$ & $50,547,863$ & & $\$$ & $20,712,811$ & $\$$ & $14,900,229$ \\
\hline & & Indirect & $\$$ & $5,646,763$ & 36 & $\$$ & $2,629,775$ & $\$$ & $1,427,838$ \\
\hline & & Induced & $\$$ & $5,087,286$ & 31 & $\$$ & $2,704,839$ & $\$$ & 992,919 \\
\hline & & Total & $\$$ & $61,282,082$ & 450 & $\$$ & $26,049,270$ & $\$$ & $17,322,014$ \\
\hline & & SAM Multiplier & & 1.21 & 1.18 & & 1.26 & & 1.16 \\
\hline & \multirow{5}{*}{2017} & Direct & $\$$ & $17,672,511$ & 148 & $\$$ & $5,295,558$ & $\$$ & $7,595,944$ \\
\hline & & Indirect & $\$$ & $3,870,734$ & 27 & $\$$ & $2,078,035$ & $\$$ & $1,150,941$ \\
\hline & & Induced & $\$$ & $5,731,911$ & 47 & $\$$ & $3,285,233$ & $\$$ & $1,658,769$ \\
\hline & & Total & $\$$ & $27,274,444$ & 222 & $\$$ & $10,658,612$ & $\$$ & $10,405,371$ \\
\hline & & SAM Multiplier & & 1.54 & 1.50 & & 2.01 & & 1.37 \\
\hline
\end{tabular}

\begin{tabular}{|c|c|c|c|c|c|c|c|c|c|}
\hline \multicolumn{3}{|c|}{ Region 1 - Ohio River Region } & \multicolumn{2}{|r|}{ Output } & \multirow{2}{*}{$\frac{\text { Employment }}{60}$} & \multicolumn{2}{|c|}{ Value Added } & \multicolumn{2}{|c|}{$\begin{array}{c}\text { Employee } \\
\text { Compensation } \\
\end{array}$} \\
\hline \multirow{10}{*}{$\begin{array}{c}\text { Pulp, Paper, } \\
\text { and } \\
\text { Paperboard }\end{array}$} & \multirow{5}{*}{2006} & Direct & $\$$ & $37,439,817$ & & $\$$ & $3,370,165$ & $\$$ & $2,409,218$ \\
\hline & & Indirect & $\$$ & $7,808,095$ & 41 & $\$$ & $3,026,700$ & $\$$ & $1,501,756$ \\
\hline & & Induced & $\$$ & $1,261,830$ & 8 & $\$$ & 670,945 & $\$$ & 246,266 \\
\hline & & Total & $\$$ & $46,492,170$ & 109 & $\$$ & $7,067,114$ & $\$$ & $4,156,676$ \\
\hline & & SAM Multiplier & & 1.24 & 1.80 & & 2.10 & & 1.73 \\
\hline & \multirow{5}{*}{2017} & Direct & $\$$ & $67,114,838$ & 98 & $\$$ & $10,122,283$ & $\$$ & $7,395,956$ \\
\hline & & Indirect & $\$$ & $24,765,291$ & 146 & $\$$ & $13,037,959$ & $\$$ & $6,362,732$ \\
\hline & & Induced & $\$$ & $10,220,076$ & 84 & $\$$ & $5,859,276$ & $\$$ & $2,957,777$ \\
\hline & & Total & $\$$ & $102,064,439$ & 329 & $\$$ & $29,013,868$ & $\$$ & $16,711,986$ \\
\hline & & SAM Multiplier & & 1.52 & 3.35 & & 2.87 & & 2.26 \\
\hline
\end{tabular}

\begin{tabular}{|c|c|c|c|c|c|c|c|c|c|}
\hline \multicolumn{3}{|c|}{ Region 1 - Ohio River Region } & \multicolumn{2}{|r|}{ Output } & \multirow{2}{*}{$\begin{array}{r}\text { Employment } \\
313\end{array}$} & \multicolumn{2}{|c|}{ Value Added } & \multicolumn{2}{|c|}{$\begin{array}{c}\text { Employee } \\
\text { Compensation }\end{array}$} \\
\hline \multirow{10}{*}{$\begin{array}{c}\text { Secondary } \\
\text { Paperboard } \\
\text { and other } \\
\text { Paper } \\
\text { Products }\end{array}$} & \multirow{5}{*}{2006} & Direct & $\$$ & $91,234,849$ & & $\$$ & $20,126,332$ & $\$$ & $18,162,165$ \\
\hline & & Indirect & $\$$ & 7,861,139 & 39 & $\$$ & $3,681,383$ & $\$$ & $2,028,547$ \\
\hline & & Induced & $\$$ & $5,856,543$ & 36 & $\$$ & $3,113,307$ & $\$$ & $1,143,240$ \\
\hline & & Total & $\$$ & $104,871,467$ & 388 & $\$$ & $26,907,964$ & $\$$ & $21,321,639$ \\
\hline & & SAM Multiplier & & 1.15 & 1.24 & & 1.34 & & 1.17 \\
\hline & \multirow{5}{*}{2017} & Direct & $\$$ & $108,324,230$ & 278 & $\$$ & $20,323,016$ & $\$$ & $15,916,248$ \\
\hline & & Indirect & $\$$ & $20,747,688$ & 124 & $\$$ & $11,281,947$ & $\$$ & $6,184,867$ \\
\hline & & Induced & $\$$ & $15,049,452$ & 124 & $\$$ & $8,626,326$ & $\$$ & $4,355,808$ \\
\hline & & Total & $\$$ & $143,972,255$ & 526 & $\$$ & $40,204,852$ & $\$$ & $26,435,821$ \\
\hline & & SAM Multiplier & & 1.33 & 1.89 & & 1.98 & & 1.66 \\
\hline
\end{tabular}


Region 2 - North Central Region: Braxton, Calhoun, Clay, Doddridge, Gilmer, Harrison, Lewis, Marion, Monongalia, Ritchie, Roane, Taylor, and Wirt counties

\begin{tabular}{|c|c|c|c|c|c|c|c|c|c|}
\hline \multicolumn{3}{|c|}{ Region 2 - North Central Region } & \multicolumn{2}{|r|}{ Output } & \multirow{2}{*}{$\begin{array}{r}\text { Employment } \\
2,221\end{array}$} & \multicolumn{2}{|c|}{ Value Added } & \multicolumn{2}{|c|}{$\begin{array}{c}\text { Employee } \\
\text { Compensation }\end{array}$} \\
\hline \multirow{10}{*}{$\begin{array}{l}\text { Forest } \\
\text { Products } \\
\text { Industry }\end{array}$} & \multirow{5}{*}{2006} & Direct & $\$$ & $534,959,971$ & & $\$$ & $147,293,866$ & $\$$ & $100,773,763$ \\
\hline & & Indirect & $\$$ & $131,442,904$ & 825 & $\$$ & $48,577,231$ & $\$$ & $23,341,252$ \\
\hline & & Induced & $\$$ & $40,457,456$ & 250 & $\$$ & $20,935,130$ & $\$$ & $7,674,495$ \\
\hline & & Total & $\$$ & $654,532,965$ & 2,917 & $\$$ & $197,919,669$ & $\$$ & $123,186,221$ \\
\hline & & SAM Multiplier & & 1.22 & 1.31 & & 1.34 & & 1.22 \\
\hline & \multirow{5}{*}{2017} & Direct & $\$$ & $303,670,004$ & 1,334 & $\$$ & $105,893,808$ & $\$$ & $59,386,532$ \\
\hline & & Indirect & $\$$ & $89,908,186$ & 571 & $\$$ & $47,384,655$ & $\$$ & $22,129,621$ \\
\hline & & Induced & $\$$ & $64,319,909$ & 515 & $\$$ & $37,131,201$ & $\$$ & $18,345,264$ \\
\hline & & Total & $\$$ & $439,139,809$ & 2,337 & $\$$ & $181,521,106$ & $\$$ & $97,554,353$ \\
\hline & & SAM Multiplier & & 1.45 & 1.75 & & 1.71 & & 1.64 \\
\hline
\end{tabular}

\begin{tabular}{|c|c|c|c|c|c|c|c|c|c|}
\hline \multicolumn{3}{|c|}{ Region 2 - North Central Region } & \multicolumn{2}{|c|}{ Output } & \multirow{2}{*}{$\begin{array}{r}\text { Employment } \\
104\end{array}$} & \multicolumn{2}{|c|}{ Value Added } & \multicolumn{2}{|c|}{$\begin{array}{c}\text { Employee } \\
\text { Compensation }\end{array}$} \\
\hline \multirow{10}{*}{ Forestry } & \multirow{5}{*}{2006} & Direct & $\$$ & $4,754,874$ & & $\$$ & $2,900,357$ & $\$$ & $1,151,257$ \\
\hline & & Indirect & $\$$ & 363,046 & 6 & $\$$ & 174,729 & $\$$ & 48,905 \\
\hline & & Induced & $\$$ & 854,079 & 5 & $\$$ & 443,052 & $\$$ & 161,729 \\
\hline & & Total & $\$$ & $5,939,789$ & 114 & $\$$ & $3,498,521$ & $\$$ & $1,354,020$ \\
\hline & & SAM Multiplier & & 1.25 & 1.10 & & 1.21 & & 1.18 \\
\hline & \multirow{5}{*}{2017} & Direct & $\$$ & $8,220,524$ & 169 & $\$$ & $7,482,207$ & $\$$ & $4,125,082$ \\
\hline & & Indirect & $\$$ & 271,305 & 4 & $\$$ & 177,258 & $\$$ & 95,441 \\
\hline & & Induced & $\$$ & $4,970,989$ & 40 & $\$$ & $2,871,563$ & $\$$ & $1,416,262$ \\
\hline & & Total & $\$$ & $13,399,224$ & 211 & $\$$ & $10,472,547$ & $\$$ & $5,603,921$ \\
\hline & & SAM Multiplier & & 1.63 & 1.25 & & 1.40 & & 1.36 \\
\hline
\end{tabular}

\begin{tabular}{|c|c|c|c|c|c|c|c|c|c|}
\hline \multicolumn{3}{|c|}{ Region 2 - North Central Region } & \multicolumn{2}{|c|}{ Output } & \multirow{2}{*}{$\begin{array}{r}\text { Employment } \\
350\end{array}$} & \multicolumn{2}{|c|}{ Value Added } & \multicolumn{2}{|c|}{$\begin{array}{c}\text { Employee } \\
\text { Compensation }\end{array}$} \\
\hline \multirow{10}{*}{ Logging } & \multirow{5}{*}{2006} & Direct & $\$$ & $33,588,392$ & & $\$$ & $15,884,035$ & $\$$ & $4,618,423$ \\
\hline & & Indirect & $\$$ & $6,508,536$ & 150 & $\$$ & $2,614,609$ & $\$$ & 934,830 \\
\hline & & Induced & $\$$ & $4,725,902$ & 29 & $\$$ & $2,452,476$ & $\$$ & 894,663 \\
\hline & & Total & $\$$ & $44,732,762$ & 528 & $\$$ & $20,917,528$ & $\$$ & $6,438,149$ \\
\hline & & SAM Multiplier & & 1.33 & 1.51 & & 1.32 & & 1.39 \\
\hline & \multirow{5}{*}{2017} & Direct & $\$$ & $44,813,755$ & 252 & $\$$ & $39,270,391$ & $\$$ & $3,803,112$ \\
\hline & & Indirect & $\$$ & $2,699,106$ & 99 & $\$$ & $1,582,653$ & $\$$ & 775,470 \\
\hline & & Induced & $\$$ & $14,512,465$ & 117 & $\$$ & $8,390,321$ & $\$$ & $4,130,554$ \\
\hline & & Total & $\$$ & $62,019,252$ & 468 & $\$$ & $49,238,044$ & $\$$ & $8,708,621$ \\
\hline & & SAM Multiplier & & 1.38 & 1.86 & & 1.25 & & 2.29 \\
\hline
\end{tabular}




\begin{tabular}{|c|c|c|c|c|c|c|c|c|c|}
\hline \multicolumn{3}{|c|}{ Region 2 - North Central Region } & \multicolumn{2}{|r|}{ Output } & \multirow{2}{*}{$\begin{array}{r}\text { Employment } \\
787\end{array}$} & \multicolumn{2}{|c|}{ Value Added } & \multicolumn{2}{|c|}{$\begin{array}{c}\text { Employee } \\
\text { Compensation }\end{array}$} \\
\hline \multirow{10}{*}{$\begin{array}{c}\text { Primary } \\
\text { Solid Wood } \\
\text { Products }\end{array}$} & \multirow{5}{*}{2006} & Direct & $\$$ & $226,289,850$ & & $\$$ & $64,070,906$ & $\$$ & $43,678,833$ \\
\hline & & Indirect & $\$$ & $78,125,713$ & 509 & $\$$ & $29,085,680$ & $\$$ & $13,239,114$ \\
\hline & & Induced & $\$$ & $19,114,136$ & 118 & $\$$ & $9,891,335$ & $\$$ & $3,625,695$ \\
\hline & & Total & $\$$ & $308,463,764$ & 1,354 & $\$$ & $99,033,252$ & $\$$ & $57,734,528$ \\
\hline & & SAM Multiplier & & 1.36 & 1.72 & & 1.55 & & 1.32 \\
\hline & \multirow{5}{*}{2017} & Direct & $\$$ & $128,949,221$ & 277 & $\$$ & $28,623,199$ & $\$$ & $18,321,717$ \\
\hline & & Indirect & $\$$ & $45,516,534$ & 236 & $\$$ & $24,647,951$ & $\$$ & $10,481,027$ \\
\hline & & Induced & $\$$ & $19,437,591$ & 156 & $\$$ & $11,217,866$ & $\$$ & $5,546,531$ \\
\hline & & Total & $\$$ & $181,677,005$ & 643 & $\$$ & $62,252,856$ & $\$$ & $33,031,464$ \\
\hline & & SAM Multiplier & & 1.41 & 2.32 & & 2.17 & & 1.80 \\
\hline
\end{tabular}

\begin{tabular}{|c|c|c|c|c|c|c|c|c|c|}
\hline \multicolumn{3}{|c|}{ Region 2 - North Central Region } & \multicolumn{2}{|r|}{ Output } & \multirow{2}{*}{$\frac{\text { Employment }}{295}$} & \multicolumn{2}{|c|}{ Value Added } & \multicolumn{2}{|c|}{$\begin{array}{c}\text { Employee } \\
\text { Compensation }\end{array}$} \\
\hline \multirow{10}{*}{$\begin{array}{c}\text { Secondary } \\
\text { Solid Wood } \\
\text { Products }\end{array}$} & \multirow{5}{*}{2006} & Direct & $\$$ & $46,700,891$ & & $\$$ & $13,718,287$ & $\$$ & $10,694,755$ \\
\hline & & Indirect & $\$$ & $11,339,012$ & 68 & $\$$ & $4,239,482$ & $\$$ & $2,357,403$ \\
\hline & & Induced & $\$$ & $4,274,297$ & 26 & $\$$ & $2,211,127$ & $\$$ & 810,976 \\
\hline & & Total & $\$$ & $61,920,487$ & 387 & $\$$ & $20,059,877$ & $\$$ & $13,787,994$ \\
\hline & & SAM Multiplier & & 1.33 & 1.31 & & 1.46 & & 1.29 \\
\hline & \multirow{5}{*}{2017} & Direct & $\$$ & $29,379,803$ & 149 & $\$$ & $7,867,923$ & $\$$ & $6,213,035$ \\
\hline & & Indirect & $\$$ & $9,963,599$ & 57 & $\$$ & $4,986,347$ & $\$$ & $2,573,026$ \\
\hline & & Induced & $\$$ & $5,933,979$ & 47 & $\$$ & $3,424,313$ & $\$$ & $1,693,369$ \\
\hline & & Total & $\$$ & $45,084,403$ & 252 & $\$$ & $16,226,661$ & $\$$ & $10,445,986$ \\
\hline & & SAM Multiplier & & 1.53 & 1.69 & & 2.06 & & 1.68 \\
\hline
\end{tabular}

\begin{tabular}{|c|c|c|c|c|c|c|c|c|c|}
\hline \multicolumn{3}{|c|}{ Region 2 - North Central Region } & \multicolumn{2}{|c|}{ Output } & \multirow{2}{*}{$\begin{array}{r}\text { Employment } \\
380\end{array}$} & \multicolumn{2}{|c|}{ Value Added } & \multicolumn{2}{|c|}{$\begin{array}{c}\text { Employee } \\
\text { Compensation }\end{array}$} \\
\hline \multirow{10}{*}{$\begin{array}{c}\text { Wood } \\
\text { Furniture }\end{array}$} & \multirow{5}{*}{2006} & Direct & $\$$ & $46,391,137$ & & $\$$ & $20,590,974$ & $\$$ & $16,398,222$ \\
\hline & & Indirect & $\$$ & $7,839,116$ & 47 & $\$$ & $3,081,309$ & $\$$ & $1,666,131$ \\
\hline & & Induced & $\$$ & $5,866,563$ & 36 & $\$$ & $3,034,595$ & $\$$ & $1,113,139$ \\
\hline & & Total & $\$$ & $60,105,812$ & 464 & $\$$ & $26,709,274$ & $\$$ & $19,179,120$ \\
\hline & & SAM Multiplier & & 1.30 & 1.22 & & 1.30 & & 1.17 \\
\hline & \multirow{5}{*}{2017} & Direct & $\$$ & $55,475,839$ & 427 & $\$$ & $17,081,154$ & $\$$ & $22,480,335$ \\
\hline & & Indirect & $\$$ & $15,386,109$ & 103 & $\$$ & $7,744,565$ & $\$$ & $4,163,649$ \\
\hline & & Induced & $\$$ & $16,190,190$ & 129 & $\$$ & $9,340,352$ & $\$$ & $4,621,499$ \\
\hline & & Total & $\$$ & $87,040,802$ & 660 & $\$$ & $34,162,642$ & $\$$ & $31,261,046$ \\
\hline & & SAM Multiplier & & 1.57 & 1.54 & & 2.00 & & 1.39 \\
\hline
\end{tabular}




\begin{tabular}{|c|c|c|c|c|c|c|c|c|c|}
\hline \multicolumn{3}{|c|}{ Region 2 - North Central Region } & \multicolumn{2}{|r|}{ Output } & \multirow{2}{*}{$\begin{array}{r}\text { Employment } \\
178\end{array}$} & \multicolumn{2}{|c|}{ Value Added } & \multicolumn{2}{|c|}{$\begin{array}{c}\text { Employee } \\
\text { Compensation }\end{array}$} \\
\hline \multirow{10}{*}{$\begin{array}{c}\text { Pulp, Paper, } \\
\text { and } \\
\text { Paperboard }\end{array}$} & \multirow{5}{*}{2006} & Direct & $\$$ & $139,244,995$ & & $\$$ & $21,984,981$ & $\$$ & $16,838,209$ \\
\hline & & Indirect & $\$$ & $33,717,677$ & 178 & $\$$ & $11,988,524$ & $\$$ & $5,928,121$ \\
\hline & & Induced & $\$$ & $7,725,786$ & 48 & $\$$ & $3,997,042$ & $\$$ & $1,465,697$ \\
\hline & & Total & $\$$ & $179,924,610$ & 402 & $\$$ & $37,854,019$ & $\$$ & $24,142,778$ \\
\hline & & SAM Multiplier & & 1.29 & 2.26 & & 1.72 & & 1.43 \\
\hline & \multirow{5}{*}{2017} & Direct & $\$$ & $36,830,863$ & 60 & $\$$ & $5,568,934$ & $\$$ & $4,443,251$ \\
\hline & & Indirect & $\$$ & $16,294,342$ & 88 & $\$$ & $8,491,978$ & $\$$ & $4,046,812$ \\
\hline & & Induced & $\$$ & $5,936,593$ & 48 & $\$$ & $3,425,688$ & $\$$ & $1,694,691$ \\
\hline & & Total & $\$$ & $58,969,394$ & 195 & $\$$ & $17,472,302$ & $\$$ & $10,173,322$ \\
\hline & & SAM Multiplier & & 1.60 & 3.24 & & 3.14 & & 2.29 \\
\hline
\end{tabular}

\begin{tabular}{|c|c|c|c|c|c|c|c|c|c|}
\hline \multicolumn{3}{|c|}{ Region 2 - North Central Region } & \multicolumn{2}{|c|}{ Output } & \multirow{2}{*}{$\begin{array}{r}\text { Employment } \\
127\end{array}$} & \multicolumn{2}{|c|}{ Value Added } & \multicolumn{2}{|c|}{$\begin{array}{c}\text { Employee } \\
\text { Compensation } \\
\end{array}$} \\
\hline \multirow{10}{*}{$\begin{array}{c}\text { Secondary } \\
\text { Paperboard } \\
\text { and other } \\
\text { Paper } \\
\text { Products }\end{array}$} & \multirow{5}{*}{2006} & Direct & $\$$ & $37,989,832$ & & $\$$ & $8,144,325$ & $\$$ & $7,394,063$ \\
\hline & & Indirect & $\$$ & $3,594,532$ & 17 & $\$$ & $1,436,701$ & $\$$ & 763,000 \\
\hline & & Induced & $\$$ & $2,549,992$ & 16 & $\$$ & $1,318,769$ & $\$$ & 483,911 \\
\hline & & Total & $\$$ & $44,109,861$ & 160 & $\$$ & $10,895,640$ & $\$$ & $8,637,083$ \\
\hline & & SAM Multiplier & & 1.16 & 1.26 & & 1.34 & & 1.17 \\
\hline & \multirow{5}{*}{2017} & Direct & $\$$ & - & - & $\$$ & - & $\$$ & - \\
\hline & & Indirect & $\$$ & - & - & $\$$ & - & $\$$ & - \\
\hline & & Induced & $\$$ & - & - & $\$$ & - & $\$$ & - \\
\hline & & Total & $\$$ & - & - & $\$$ & - & $\$$ & - \\
\hline & & SAM Multiplier & & & & & & & \\
\hline
\end{tabular}


Region 3 - Highlands Region: Barbour, Greenbrier, Monroe, Nicholas, Pendleton, Pocahontas, Preston, Randolph, Tucker, Upshur, and Webster counties

\begin{tabular}{|c|c|c|c|c|c|c|c|c|c|}
\hline \multicolumn{3}{|c|}{ Region 3 - Highlands Region } & \multicolumn{2}{|r|}{ Output } & \multirow{2}{*}{$\frac{\text { Employment }}{6,210}$} & \multicolumn{2}{|c|}{ Value Added } & \multicolumn{2}{|c|}{$\begin{array}{c}\text { Employee } \\
\text { Compensation }\end{array}$} \\
\hline \multirow{10}{*}{$\begin{array}{l}\text { Forest } \\
\text { Products } \\
\text { Industry }\end{array}$} & \multirow{5}{*}{2006} & Direct & $\$$ & $1,042,080,710$ & & $\$$ & $375,917,108$ & $\$$ & $256,688,499$ \\
\hline & & Indirect & $\$$ & $266,042,204$ & 1,799 & $\$$ & $106,216,727$ & $\$$ & $54,542,389$ \\
\hline & & Induced & $\$$ & $68,442,514$ & 393 & $\$$ & $35,412,621$ & $\$$ & $10,471,935$ \\
\hline & & Total & $\$$ & $1,185,316,170$ & 7,077 & $\$$ & $440,656,430$ & $\$$ & $282,886,988$ \\
\hline & & SAM Multiplier & & 1.14 & 1.14 & & 1.17 & & 1.10 \\
\hline & \multirow{5}{*}{2017} & Direct & $\$$ & $991,504,755$ & 4,395 & $\$$ & $364,553,708$ & $\$$ & $178,581,244$ \\
\hline & & Indirect & $\$$ & $343,074,368$ & 2,003 & $\$$ & $179,272,142$ & $\$$ & $63,775,215$ \\
\hline & & Induced & $\$$ & $148,717,973$ & 1,363 & $\$$ & $81,543,627$ & $\$$ & $37,376,267$ \\
\hline & & Total & & $1,305,154,155$ & 6,955 & $\$$ & $526,727,699$ & $\$$ & $255,032,811$ \\
\hline & & SAM Multiplier & & 1.32 & 1.58 & & 1.44 & & 1.43 \\
\hline
\end{tabular}

\begin{tabular}{|c|c|c|c|c|c|c|c|c|c|}
\hline \multicolumn{3}{|c|}{ Region 3 - Highlands Region } & \multicolumn{2}{|c|}{ Output } & \multirow{2}{*}{$\begin{array}{r}\text { Employment } \\
168\end{array}$} & \multicolumn{2}{|c|}{ Value Added } & \multicolumn{2}{|c|}{$\begin{array}{c}\text { Employee } \\
\text { Compensation }\end{array}$} \\
\hline \multirow{10}{*}{ Forestry } & \multirow{5}{*}{2006} & Direct & $\$$ & $11,884,278$ & & $\$$ & $8,373,275$ & $\$$ & $3,276,766$ \\
\hline & & Indirect & $\$$ & 578,220 & 5 & $\$$ & 291,245 & $\$$ & 68,519 \\
\hline & & Induced & $\$$ & $1,768,210$ & 10 & $\$$ & 917,657 & $\$$ & 269,353 \\
\hline & & Total & $\$$ & $14,121,100$ & 182 & $\$$ & $9,504,084$ & $\$$ & $3,584,528$ \\
\hline & & SAM Multiplier & & 1.19 & 1.08 & & 1.14 & & 1.09 \\
\hline & \multirow{5}{*}{2017} & Direct & $\$$ & $4,426,815$ & 157 & $\$$ & $3,711,620$ & $\$$ & $3,224,002$ \\
\hline & & Indirect & $\$$ & 207,544 & 4 & $\$$ & 108,904 & $\$$ & 70,239 \\
\hline & & Induced & $\$$ & $2,013,936$ & 18 & $\$$ & $1,104,139$ & $\$$ & 505,881 \\
\hline & & Total & $\$$ & $6,605,331$ & 177 & $\$$ & $4,888,665$ & $\$$ & $3,762,658$ \\
\hline & & SAM Multiplier & & 1.49 & 1.13 & & 1.32 & & 1.17 \\
\hline
\end{tabular}

\begin{tabular}{|c|c|c|c|c|c|c|c|c|c|}
\hline \multicolumn{3}{|c|}{ Region 3 - Highlands Region } & \multicolumn{2}{|r|}{ Output } & \multirow{2}{*}{$\begin{array}{r}\text { Employment } \\
1,192\end{array}$} & \multicolumn{2}{|c|}{ Value Added } & \multicolumn{2}{|c|}{$\begin{array}{c}\text { Employee } \\
\text { Compensation }\end{array}$} \\
\hline \multirow{10}{*}{ Logging } & \multirow{5}{*}{2006} & Direct & $\$$ & $127,134,390$ & & $\$$ & $67,280,292$ & $\$$ & $24,716,407$ \\
\hline & & Indirect & $\$$ & $14,631,858$ & 154 & $\$$ & $6,255,199$ & $\$$ & $2,547,311$ \\
\hline & & Induced & $\$$ & $13,658,988$ & 78 & $\$$ & $7,087,507$ & $\$$ & $2,081,184$ \\
\hline & & Total & $\$$ & $154,910,592$ & 1,419 & $\$$ & $80,388,726$ & $\$$ & $29,258,838$ \\
\hline & & SAM Multiplier & & 1.22 & 1.19 & & 1.19 & & 1.18 \\
\hline & \multirow{5}{*}{2017} & Direct & $\$$ & $200,706,223$ & 979 & $\$$ & $179,225,465$ & $\$$ & $21,201,233$ \\
\hline & & Indirect & $\$$ & $7,220,745$ & 161 & $\$$ & $3,825,303$ & $\$$ & $2,041,939$ \\
\hline & & Induced & $\$$ & $48,142,131$ & 442 & $\$$ & $26,428,323$ & $\$$ & $12,079,968$ \\
\hline & & Total & $\$$ & $255,952,001$ & 1,581 & $\$$ & $209,374,528$ & $\$$ & $35,310,771$ \\
\hline & & SAM Multiplier & & 1.28 & 1.62 & & 1.17 & & 1.67 \\
\hline
\end{tabular}




\begin{tabular}{|c|c|c|c|c|c|c|c|c|c|}
\hline \multicolumn{3}{|c|}{ Region 3 - Highlands Region } & \multicolumn{2}{|r|}{ Output } & \multirow{2}{*}{$\begin{array}{r}\text { Employment } \\
1,363\end{array}$} & \multicolumn{2}{|c|}{ Value Added } & \multicolumn{2}{|c|}{$\begin{array}{c}\text { Employee } \\
\text { Compensation }\end{array}$} \\
\hline \multirow{10}{*}{$\begin{array}{c}\text { Primary } \\
\text { Solid Wood } \\
\text { Products }\end{array}$} & \multirow{5}{*}{2006} & Direct & $\$$ & $301,579,358$ & & $\$$ & $83,078,559$ & $\$$ & $66,255,439$ \\
\hline & & Indirect & $\$$ & $134,417,742$ & 1,011 & $\$$ & $59,216,419$ & $\$$ & $26,698,079$ \\
\hline & & Induced & $\$$ & $23,647,481$ & 136 & $\$$ & $12,240,603$ & $\$$ & $3,615,899$ \\
\hline & & Total & $\$$ & $431,594,114$ & 2,385 & $\$$ & $146,906,495$ & $\$$ & $90,709,304$ \\
\hline & & SAM Multiplier & & 1.43 & 1.75 & & 1.77 & & 1.37 \\
\hline & \multirow{5}{*}{2017} & Direct & $\$$ & $457,325,438$ & 1,643 & $\$$ & $88,627,456$ & $\$$ & $75,906,690$ \\
\hline & & Indirect & $\$$ & $235,821,550$ & 1,326 & $\$$ & $135,506,935$ & $\$$ & $41,648,151$ \\
\hline & & Induced & $\$$ & $72,301,051$ & 663 & $\$$ & $39,640,609$ & $\$$ & $18,172,531$ \\
\hline & & Total & $\$$ & $720,372,888$ & 3,466 & $\$$ & $255,303,311$ & $\$$ & $128,389,523$ \\
\hline & & SAM Multiplier & & 1.58 & 2.11 & & 2.88 & & 1.69 \\
\hline
\end{tabular}

\begin{tabular}{|c|c|c|c|c|c|c|c|c|c|}
\hline \multicolumn{3}{|c|}{ Region 3 - Highlands Region } & \multicolumn{2}{|r|}{ Output } & \multirow{2}{*}{$\begin{array}{r}\text { Employment } \\
2,812\end{array}$} & \multicolumn{2}{|c|}{ Value Added } & \multicolumn{2}{|c|}{$\begin{array}{c}\text { Employee } \\
\text { Compensation } \\
\end{array}$} \\
\hline \multirow{10}{*}{$\begin{array}{c}\text { Secondary } \\
\text { Solid Wood } \\
\text { Products }\end{array}$} & \multirow{5}{*}{2006} & Direct & $\$$ & $525,877,216$ & & $\$$ & $187,406,466$ & $\$$ & $135,937,345$ \\
\hline & & Indirect & $\$$ & $145,583,858$ & 895 & $\$$ & $53,929,493$ & $\$$ & $30,427,635$ \\
\hline & & Induced & $\$$ & $37,642,712$ & 216 & $\$$ & $19,466,529$ & $\$$ & $5,763,779$ \\
\hline & & Total & $\$$ & $695,346,077$ & 3,849 & $\$$ & $256,025,278$ & $\$$ & $169,100,421$ \\
\hline & & SAM Multiplier & & 1.32 & 1.37 & & 1.37 & & 1.24 \\
\hline & \multirow{5}{*}{2017} & Direct & $\$$ & $266,756,648$ & 1,290 & $\$$ & $81,359,770$ & $\$$ & $65,332,489$ \\
\hline & & Indirect & $\$$ & $104,262,249$ & 583 & $\$$ & $44,827,429$ & $\$$ & $20,439,089$ \\
\hline & & Induced & $\$$ & $45,876,313$ & 420 & $\$$ & $25,142,740$ & $\$$ & $11,537,328$ \\
\hline & & Total & $\$$ & $411,943,122$ & 2,269 & $\$$ & $149,894,765$ & $\$$ & $96,245,110$ \\
\hline & & SAM Multiplier & & 1.54 & 1.76 & & 1.84 & & 1.47 \\
\hline
\end{tabular}

\begin{tabular}{|c|c|c|c|c|c|c|c|c|c|}
\hline \multicolumn{3}{|c|}{ Region 3 - Highlands Region } & \multicolumn{2}{|c|}{ Output } & \multirow{2}{*}{$\begin{array}{r}\text { Employment } \\
674\end{array}$} & \multicolumn{2}{|c|}{ Value Added } & \multicolumn{2}{|c|}{$\begin{array}{c}\text { Employee } \\
\text { Compensation }\end{array}$} \\
\hline \multirow{10}{*}{$\begin{array}{l}\text { Wood } \\
\text { Furniture }\end{array}$} & \multirow{5}{*}{2006} & Direct & $\$$ & $75,605,467$ & & $\$$ & $29,778,516$ & $\$$ & $26,502,542$ \\
\hline & & Indirect & $\$$ & $11,086,594$ & 69 & $\$$ & $4,146,450$ & $\$$ & $2,522,715$ \\
\hline & & Induced & $\$$ & $6,514,342$ & 37 & $\$$ & $3,368,258$ & $\$$ & 997,705 \\
\hline & & Total & $\$$ & $93,202,893$ & 781 & $\$$ & $37,291,395$ & $\$$ & $30,021,612$ \\
\hline & & SAM Multiplier & & 1.23 & 1.16 & & 1.25 & & 1.13 \\
\hline & \multirow{5}{*}{2017} & Direct & $\$$ & $35,496,794$ & 281 & $\$$ & $8,240,531$ & $\$$ & $10,321,243$ \\
\hline & & Indirect & $\$$ & $9,177,575$ & 61 & $\$$ & $3,900,946$ & $\$$ & $2,024,254$ \\
\hline & & Induced & $\$$ & $6,096,894$ & 56 & $\$$ & $3,340,853$ & $\$$ & $1,533,034$ \\
\hline & & Total & $\$$ & $50,766,252$ & 397 & $\$$ & $15,481,193$ & $\$$ & $13,877,132$ \\
\hline & & SAM Multiplier & & 1.43 & 1.41 & & 1.88 & & 1.34 \\
\hline
\end{tabular}




\begin{tabular}{|c|c|c|c|c|c|c|c|c|c|}
\hline \multicolumn{3}{|c|}{ Region 3 - Highlands Region } & \multicolumn{2}{|c|}{ Output } & \multirow{2}{*}{$\begin{array}{c}\text { Employment } \\
-\end{array}$} & \multicolumn{2}{|c|}{ Value Added } & \multicolumn{2}{|c|}{$\begin{array}{c}\text { Employee } \\
\text { Compensation }\end{array}$} \\
\hline \multirow{10}{*}{$\begin{array}{c}\text { Pulp, Paper, } \\
\text { and } \\
\text { Paperboard }\end{array}$} & \multirow{5}{*}{2006} & Direct & $\$$ & - & & $\$$ & - & $\$$ & - \\
\hline & & Indirect & $\$$ & - & - & $\$$ & - & $\$$ & - \\
\hline & & Induced & $\$$ & - & - & $\$$ & - & $\$$ & - \\
\hline & & Total & $\$$ & - & - & $\$$ & - & $\$$ & - \\
\hline & & SAM Multiplier & & & & & & & \\
\hline & \multirow{5}{*}{2017} & Direct & $\$$ & $26,792,837$ & 45 & $\$$ & $3,388,866$ & $\$$ & $2,595,587$ \\
\hline & & Indirect & $\$$ & $11,357,440$ & 65 & $\$$ & $5,298,058$ & $\$$ & $2,321,143$ \\
\hline & & Induced & $\$$ & $3,054,468$ & 28 & $\$$ & $1,674,221$ & $\$$ & 768,489 \\
\hline & & Total & $\$$ & $41,169,091$ & 138 & $\$$ & $10,356,659$ & $\$$ & $5,681,671$ \\
\hline & & SAM Multiplier & & 1.54 & 3.05 & & 3.06 & & 2.19 \\
\hline
\end{tabular}

\begin{tabular}{|c|c|c|c|c|c|c|c|c|c|}
\hline \multirow{10}{*}{$\begin{array}{c}\text { Secondary } \\
\text { Paperboard } \\
\text { and other } \\
\text { Paper } \\
\text { Products }\end{array}$} & \multirow{5}{*}{2006} & Direct & $\$$ & - & - & $\$$ & - & $\$$ & - \\
\hline & & Indirect & $\$$ & - & - & $\$$ & - & $\$$ & - \\
\hline & & Induced & $\$$ & - & - & $\$$ & - & $\$$ & - \\
\hline & & Total & $\$$ & - & - & $\$$ & - & $\$$ & - \\
\hline & & SAM Multiplier & & & & & & & \\
\hline & \multirow{5}{*}{2017} & Direct & $\$$ & - & - & $\$$ & - & $\$$ & - \\
\hline & & Indirect & $\$$ & - & - & $\$$ & - & $\$$ & - \\
\hline & & Induced & $\$$ & - & - & $\$$ & - & $\$$ & - \\
\hline & & Total & $\$$ & - & - & $\$$ & - & $\$$ & - \\
\hline & & SAM Multiplier & & & & & & & \\
\hline
\end{tabular}




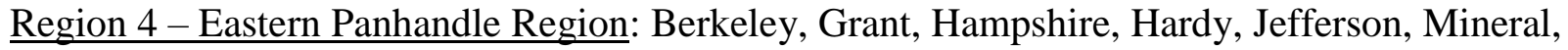
and Morgan counties

\begin{tabular}{|c|c|c|c|c|c|c|c|c|c|}
\hline \multicolumn{3}{|c|}{ Region 4 - Eastern Panhandle Region } & \multicolumn{2}{|r|}{ Output } & \multirow{2}{*}{$\begin{array}{r}\text { Employment } \\
2,823\end{array}$} & \multicolumn{2}{|c|}{ Value Added } & \multicolumn{2}{|c|}{$\begin{array}{c}\text { Employee } \\
\text { Compensation }\end{array}$} \\
\hline \multirow{10}{*}{$\begin{array}{c}\text { Forest } \\
\text { Products } \\
\text { Industry }\end{array}$} & \multirow{5}{*}{2006} & Direct & $\$$ & $540,495,590$ & & $\$$ & $160,599,560$ & $\$$ & $114,748,353$ \\
\hline & & Indirect & $\$$ & $106,562,835$ & 640 & $\$$ & $39,625,345$ & $\$$ & $22,494,354$ \\
\hline & & Induced & $\$$ & $27,378,892$ & 121 & $\$$ & $14,540,684$ & $\$$ & $3,693,886$ \\
\hline & & Total & $\$$ & $611,932,475$ & 3,185 & $\$$ & $194,349,901$ & $\$$ & $128,276,627$ \\
\hline & & SAM Multiplier & & 1.13 & 1.13 & & 1.21 & & 1.12 \\
\hline & \multirow{5}{*}{2017} & Direct & $\$$ & $350,231,869$ & 1,914 & $\$$ & $108,814,789$ & $\$$ & $72,832,057$ \\
\hline & & Indirect & $\$$ & $95,738,403$ & 636 & $\$$ & $49,734,752$ & $\$$ & $22,124,843$ \\
\hline & & Induced & $\$$ & $55,282,743$ & 478 & $\$$ & $30,610,804$ & $\$$ & $13,549,405$ \\
\hline & & Total & $\$$ & $475,807,068$ & 2,905 & $\$$ & $175,786,366$ & $\$$ & $104,926,537$ \\
\hline & & SAM Multiplier & & 1.36 & 1.52 & & 1.62 & & 1.44 \\
\hline
\end{tabular}

\begin{tabular}{|c|c|c|c|c|c|c|c|c|c|}
\hline \multicolumn{3}{|c|}{ Region 4 - Eastern Panhandle Region } & \multicolumn{2}{|c|}{ Output } & \multirow{2}{*}{$\begin{array}{r}\text { Employment } \\
134\end{array}$} & \multicolumn{2}{|c|}{ Value Added } & \multicolumn{2}{|c|}{$\begin{array}{c}\text { Employee } \\
\text { Compensation } \\
\end{array}$} \\
\hline \multirow{10}{*}{ Forestry } & \multirow{5}{*}{2006} & Direct & $\$$ & $6,727,351$ & & $\$$ & $4,011,743$ & $\$$ & $2,445,990$ \\
\hline & & Indirect & $\$$ & 389,434 & 6 & $\$$ & 191,039 & $\$$ & 75,689 \\
\hline & & Induced & $\$$ & 721,986 & 3 & $\$$ & 383,804 & $\$$ & 97,369 \\
\hline & & Total & $\$$ & $7,751,687$ & 141 & $\$$ & $4,533,430$ & $\$$ & $2,585,054$ \\
\hline & & SAM Multiplier & & 1.15 & 1.05 & & 1.13 & & 1.06 \\
\hline & \multirow{5}{*}{2017} & Direct & $\$$ & $6,151,674$ & 225 & $\$$ & $5,070,084$ & $\$$ & $4,445,518$ \\
\hline & & Indirect & $\$$ & 321,258 & 6 & $\$$ & 177,081 & $\$$ & 120,828 \\
\hline & & Induced & $\$$ & $2,773,982$ & 24 & $\$$ & $1,536,107$ & $\$$ & 679,573 \\
\hline & & Total & $\$$ & $9,173,202$ & 251 & $\$$ & $6,721,959$ & $\$$ & $5,180,984$ \\
\hline & & SAM Multiplier & & 1.49 & 1.12 & & 1.33 & & 1.17 \\
\hline
\end{tabular}

\begin{tabular}{|c|c|c|c|c|c|c|c|c|c|}
\hline \multicolumn{3}{|c|}{ Region 4 - Eastern Panhandle Region } & \multicolumn{2}{|c|}{ Output } & \multirow{2}{*}{$\frac{\text { Employment }}{222}$} & \multicolumn{2}{|c|}{ Value Added } & \multicolumn{2}{|c|}{$\begin{array}{c}\text { Employee } \\
\text { Compensation } \\
\end{array}$} \\
\hline \multirow{10}{*}{ Logging } & \multirow{5}{*}{2006} & Direct & $\$$ & $20,783,002$ & & $\$$ & $9,537,831$ & $\$$ & $4,437,998$ \\
\hline & & Indirect & $\$$ & $3,482,091$ & 56 & $\$$ & $1,425,507$ & $\$$ & 690,833 \\
\hline & & Induced & $\$$ & $1,770,433$ & 8 & $\$$ & 941,595 & $\$$ & 238,718 \\
\hline & & Total & $\$$ & $26,009,348$ & 286 & $\$$ & $11,898,332$ & $\$$ & $5,364,478$ \\
\hline & & SAM Multiplier & & 1.25 & 1.29 & & 1.25 & & 1.21 \\
\hline & \multirow{5}{*}{2017} & Direct & $\$$ & $27,830,706$ & 152 & $\$$ & $24,502,959$ & $\$$ & $2,546,538$ \\
\hline & & Indirect & $\$$ & $1,741,495$ & 37 & $\$$ & $1,005,309$ & $\$$ & 397,608 \\
\hline & & Induced & $\$$ & $7,662,049$ & 66 & $\$$ & $4,248,828$ & $\$$ & $1,874,132$ \\
\hline & & Total & $\$$ & $37,230,780$ & 255 & $\$$ & $29,754,041$ & $\$$ & $4,817,960$ \\
\hline & & SAM Multiplier & & 1.34 & 1.68 & & 1.21 & & 1.89 \\
\hline
\end{tabular}




\begin{tabular}{|c|c|c|c|c|c|c|c|c|c|}
\hline \multicolumn{3}{|c|}{ Region 4 - Eastern Panhandle Region } & \multicolumn{2}{|r|}{ Output } & \multirow{2}{*}{$\begin{array}{r}\text { Employment } \\
1,336\end{array}$} & \multicolumn{2}{|c|}{ Value Added } & \multicolumn{2}{|c|}{$\begin{array}{c}\text { Employee } \\
\text { Compensation }\end{array}$} \\
\hline \multirow{10}{*}{$\begin{array}{c}\text { Primary } \\
\text { Solid Wood } \\
\text { Products }\end{array}$} & \multirow{5}{*}{2006} & Direct & $\$$ & $304,540,093$ & & $\$$ & $81,897,712$ & $\$$ & $60,930,187$ \\
\hline & & Indirect & $\$$ & $76,497,796$ & 484 & $\$$ & $28,670,002$ & $\$$ & $16,102,321$ \\
\hline & & Induced & $\$$ & $15,665,138$ & 69 & $\$$ & $8,319,636$ & $\$$ & $2,113,494$ \\
\hline & & Total & $\$$ & $366,912,683$ & 1,757 & $\$$ & $111,143,785$ & $\$$ & $73,411,438$ \\
\hline & & SAM Multiplier & & 1.20 & 1.32 & & 1.36 & & 1.20 \\
\hline & \multirow{5}{*}{2017} & Direct & $\$$ & $99,213,517$ & 278 & $\$$ & $20,662,188$ & $\$$ & $14,635,272$ \\
\hline & & Indirect & $\$$ & $36,777,506$ & 233 & $\$$ & $21,123,026$ & $\$$ & $8,046,015$ \\
\hline & & Induced & $\$$ & $14,097,454$ & 122 & $\$$ & $7,806,941$ & $\$$ & $3,454,639$ \\
\hline & & Total & $\$$ & $145,980,692$ & 619 & $\$$ & $48,750,957$ & $\$$ & $25,425,534$ \\
\hline & & SAM Multiplier & & 1.47 & 2.22 & & 2.36 & & 1.74 \\
\hline
\end{tabular}

\begin{tabular}{|c|c|c|c|c|c|c|c|c|c|}
\hline \multicolumn{3}{|c|}{ Region 4 - Eastern Panhandle Region } & \multicolumn{2}{|r|}{ Output } & \multirow{2}{*}{$\frac{\text { Employment }}{592}$} & \multicolumn{2}{|c|}{ Value Added } & \multicolumn{2}{|c|}{$\begin{array}{c}\text { Employee } \\
\text { Compensation } \\
\end{array}$} \\
\hline \multirow{10}{*}{$\begin{array}{c}\text { Secondary } \\
\text { Solid Wood } \\
\text { Products }\end{array}$} & \multirow{5}{*}{2006} & Direct & $\$$ & $100,113,092$ & & $\$$ & $33,995,863$ & $\$$ & $23,701,467$ \\
\hline & & Indirect & $\$$ & $19,796,028$ & 103 & $\$$ & $6,983,328$ & $\$$ & $4,337,264$ \\
\hline & & Induced & $\$$ & $6,037,503$ & 27 & $\$$ & $3,206,302$ & $\$$ & 814,580 \\
\hline & & Total & $\$$ & $125,091,175$ & 717 & $\$$ & $43,877,378$ & $\$$ & $28,669,229$ \\
\hline & & SAM Multiplier & & 1.25 & 1.21 & & 1.29 & & 1.21 \\
\hline & \multirow{5}{*}{2017} & Direct & $\$$ & $158,314,132$ & 869 & $\$$ & $46,813,470$ & $\$$ & $36,202,560$ \\
\hline & & Indirect & $\$$ & $44,834,237$ & 289 & $\$$ & $21,914,573$ & $\$$ & $10,531,827$ \\
\hline & & Induced & $\$$ & $25,748,506$ & 223 & $\$$ & $14,255,135$ & $\$$ & $6,311,998$ \\
\hline & & Total & $\$$ & $227,503,392$ & 1,373 & $\$$ & $82,582,203$ & $\$$ & $52,739,666$ \\
\hline & & SAM Multiplier & & 1.44 & 1.58 & & 1.76 & & 1.46 \\
\hline
\end{tabular}

\begin{tabular}{|c|c|c|c|c|c|c|c|c|c|}
\hline \multicolumn{3}{|c|}{ Region 4 - Eastern Panhandle Region } & \multicolumn{2}{|c|}{ Output } & \multirow{2}{*}{$\begin{array}{r}\text { Employment } \\
442\end{array}$} & \multicolumn{2}{|c|}{ Value Added } & \multicolumn{2}{|c|}{$\begin{array}{c}\text { Employee } \\
\text { Compensation }\end{array}$} \\
\hline \multirow{10}{*}{$\begin{array}{c}\text { Wood } \\
\text { Furniture }\end{array}$} & \multirow{5}{*}{2006} & Direct & $\$$ & $56,019,216$ & & $\$$ & $23,251,812$ & $\$$ & $17,658,104$ \\
\hline & & Indirect & $\$$ & $6,143,556$ & 36 & $\$$ & $2,439,275$ & $\$$ & $1,342,318$ \\
\hline & & Induced & $\$$ & $4,078,729$ & 18 & $\$$ & $2,165,983$ & $\$$ & 550,311 \\
\hline & & Total & $\$$ & $66,249,042$ & 495 & $\$$ & $27,860,054$ & $\$$ & $19,552,804$ \\
\hline & & SAM Multiplier & & 1.18 & 1.12 & & 1.20 & & 1.11 \\
\hline & \multirow{5}{*}{2017} & Direct & $\$$ & $40,819,104$ & 366 & $\$$ & $9,662,704$ & $\$$ & $13,617,443$ \\
\hline & & Indirect & $\$$ & $9,835,635$ & 71 & $\$$ & $4,694,830$ & $\$$ & $2,486,993$ \\
\hline & & Induced & $\$$ & $7,645,743$ & 66 & $\$$ & $4,231,504$ & $\$$ & $1,874,658$ \\
\hline & & Total & $\$$ & $58,296,274$ & 504 & $\$$ & $18,588,006$ & $\$$ & $17,977,669$ \\
\hline & & SAM Multiplier & & 1.43 & 1.38 & & 1.92 & & 1.32 \\
\hline
\end{tabular}




\begin{tabular}{|c|c|c|c|c|c|c|c|c|c|}
\hline \multicolumn{3}{|c|}{ Region 4 - Eastern Panhandle Region } & \multicolumn{2}{|c|}{ Output } & \multirow{2}{*}{$\begin{array}{r}\text { Employment } \\
99\end{array}$} & \multicolumn{2}{|c|}{ Value Added } & \multicolumn{2}{|c|}{$\begin{array}{c}\text { Employee } \\
\text { Compensation }\end{array}$} \\
\hline \multirow{10}{*}{$\begin{array}{c}\text { Pulp, Paper, } \\
\text { and } \\
\text { Paperboard }\end{array}$} & \multirow{5}{*}{2006} & Direct & $\$$ & $52,312,837$ & & $\$$ & $7,904,600$ & $\$$ & $5,574,607$ \\
\hline & & Indirect & $\$$ & $6,845,096$ & 27 & $\$$ & $2,501,067$ & $\$$ & $1,301,387$ \\
\hline & & Induced & $\$$ & $1,466,077$ & 6 & $\$$ & 778,479 & $\$$ & 197,818 \\
\hline & & Total & $\$$ & $60,618,871$ & 133 & $\$$ & $11,185,716$ & $\$$ & $7,074,920$ \\
\hline & & SAM Multiplier & & 1.16 & 1.34 & & 1.42 & & 1.27 \\
\hline & \multirow{5}{*}{2017} & Direct & $\$$ & $17,902,737$ & 25 & $\$$ & $2,103,385$ & $\$$ & $1,384,725$ \\
\hline & & Indirect & $\$$ & $6,276,771$ & 37 & $\$$ & $3,201,804$ & $\$$ & $1,431,547$ \\
\hline & & Induced & $\$$ & $2,009,580$ & 17 & $\$$ & $1,112,375$ & $\$$ & 493,480 \\
\hline & & Total & $\$$ & $26,187,464$ & 79 & $\$$ & $6,417,374$ & $\$$ & $3,309,626$ \\
\hline & & SAM Multiplier & & 1.46 & 3.20 & & 3.05 & & 2.39 \\
\hline
\end{tabular}

\begin{tabular}{|c|c|c|c|c|c|c|c|c|c|}
\hline \multicolumn{3}{|c|}{ Region 4 - Eastern Panhandle Region } & \multicolumn{2}{|c|}{ Output } & \multirow{2}{*}{$\begin{array}{r}\text { Employment } \\
-\end{array}$} & \multicolumn{2}{|c|}{ Value Added } & \multicolumn{2}{|c|}{$\begin{array}{c}\text { Employee } \\
\text { Compensation }\end{array}$} \\
\hline \multirow{10}{*}{$\begin{array}{c}\text { Secondary } \\
\text { Paperboard } \\
\text { and other } \\
\text { Paper } \\
\text { Products }\end{array}$} & \multirow{5}{*}{2006} & Direct & $\$$ & - & & $\$$ & - & $\$$ & - \\
\hline & & Indirect & $\$$ & - & - & $\$$ & - & $\$$ & - \\
\hline & & Induced & $\$$ & - & - & $\$$ & - & $\$$ & - \\
\hline & & Total & $\$$ & - & - & $\$$ & - & $\$$ & - \\
\hline & & SAM Multiplier & & & & & & & \\
\hline & \multirow{5}{*}{2017} & Direct & $\$$ & - & - & $\$$ & - & $\$$ & - \\
\hline & & Indirect & $\$$ & - & - & $\$$ & - & $\$$ & - \\
\hline & & Induced & $\$$ & - & - & $\$$ & - & $\$$ & - \\
\hline & & Total & $\$$ & - & - & $\$$ & - & $\$$ & - \\
\hline & & SAM Multiplier & & & & & & & \\
\hline
\end{tabular}


Region 5 - Southern Region: Boone, Fayette, Kanawha, Lincoln, Logan, McDowell, Mercer, Mingo, Raleigh, Summers, Wayne, and Wyoming counties

\begin{tabular}{|c|c|c|c|c|c|c|c|c|c|}
\hline \multicolumn{3}{|c|}{ Region 5 - Southern Region } & \multicolumn{2}{|r|}{ Output } & \multirow{2}{*}{$\frac{\text { Employment }}{2,049}$} & \multicolumn{2}{|c|}{ Value Added } & \multicolumn{2}{|c|}{$\begin{array}{c}\text { Employee } \\
\text { Compensation }\end{array}$} \\
\hline \multirow{10}{*}{$\begin{array}{c}\text { Forest } \\
\text { Products } \\
\text { Industry }\end{array}$} & \multirow{5}{*}{2006} & Direct & $\$$ & $364,335,429$ & & $\$$ & $125,868,129$ & $\$$ & $84,335,405$ \\
\hline & & Indirect & $\$$ & $100,683,794$ & 702 & $\$$ & $46,842,816$ & $\$$ & $26,234,924$ \\
\hline & & Induced & $\$$ & $44,006,369$ & 305 & $\$$ & $24,843,405$ & $\$$ & $10,620,398$ \\
\hline & & Total & $\$$ & $460,614,165$ & 2,689 & $\$$ & $176,957,273$ & $\$$ & $109,544,875$ \\
\hline & & SAM Multiplier & & 1.26 & 1.31 & & 1.41 & & 1.30 \\
\hline & \multirow{5}{*}{2017} & Direct & $\$$ & $318,049,227$ & 1,550 & $\$$ & $111,943,057$ & $\$$ & $52,212,276$ \\
\hline & & Indirect & $\$$ & $119,332,972$ & 704 & $\$$ & $70,365,520$ & $\$$ & $29,240,391$ \\
\hline & & Induced & $\$$ & $67,358,013$ & 530 & $\$$ & $39,706,247$ & $\$$ & $19,922,501$ \\
\hline & & Total & $\$$ & $466,123,428$ & 2,579 & $\$$ & $197,538,491$ & $\$$ & $96,312,825$ \\
\hline & & SAM Multiplier & & 1.47 & 1.66 & & 1.76 & & 1.84 \\
\hline
\end{tabular}

\begin{tabular}{|c|c|c|c|c|c|c|c|c|c|}
\hline \multicolumn{3}{|c|}{ Region 1 - Ohio River Region } & \multicolumn{2}{|c|}{ Output } & \multirow{2}{*}{$\begin{array}{r}\text { Employment } \\
75\end{array}$} & \multicolumn{2}{|c|}{ Value Added } & \multicolumn{2}{|c|}{$\begin{array}{c}\text { Employee } \\
\text { Compensation } \\
\end{array}$} \\
\hline \multirow{10}{*}{ Forestry } & \multirow{5}{*}{2006} & Direct & $\$$ & $3,360,509$ & & $\$$ & $2,088,403$ & $\$$ & 947,427 \\
\hline & & Indirect & $\$$ & 282,382 & 2 & $\$$ & 142,655 & $\$$ & 53,063 \\
\hline & & Induced & $\$$ & 808,414 & 6 & $\$$ & 455,465 & $\$$ & 194,599 \\
\hline & & Total & $\$$ & $4,450,923$ & 83 & $\$$ & $2,686,626$ & $\$$ & $1,195,134$ \\
\hline & & SAM Multiplier & & 1.32 & 1.10 & & 1.29 & & 1.26 \\
\hline & \multirow{5}{*}{2017} & Direct & $\$$ & $3,945,094$ & 127 & $\$$ & $3,297,807$ & $\$$ & $3,188,684$ \\
\hline & & Indirect & $\$$ & 348,381 & 5 & $\$$ & 207,092 & $\$$ & 145,658 \\
\hline & & Induced & $\$$ & $2,550,375$ & 20 & $\$$ & $1,503,098$ & $\$$ & 754,387 \\
\hline & & Total & $\$$ & $6,757,498$ & 148 & $\$$ & $4,933,790$ & $\$$ & $4,006,197$ \\
\hline & & SAM Multiplier & & 1.71 & 1.17 & & 1.50 & & 1.26 \\
\hline
\end{tabular}

\begin{tabular}{|c|c|c|c|c|c|c|c|c|c|}
\hline \multicolumn{3}{|c|}{ Region 5 - Southern Region } & \multicolumn{2}{|r|}{ Output } & \multirow{2}{*}{$\frac{\text { Employment }}{476}$} & \multicolumn{2}{|c|}{ Value Added } & \multicolumn{2}{|c|}{$\begin{array}{c}\text { Employee } \\
\text { Compensation } \\
\end{array}$} \\
\hline \multirow{10}{*}{ Logging } & \multirow{5}{*}{2006} & Direct & $\$$ & $50,737,100$ & & $\$$ & $26,818,680$ & $\$$ & $13,863,666$ \\
\hline & & Indirect & $\$$ & $8,967,074$ & 84 & $\$$ & $4,026,456$ & $\$$ & $1,701,966$ \\
\hline & & Induced & $\$$ & $9,331,569$ & 65 & $\$$ & $5,261,940$ & $\$$ & $2,248,715$ \\
\hline & & Total & $\$$ & $68,902,650$ & 624 & $\$$ & $36,051,927$ & $\$$ & $17,785,838$ \\
\hline & & SAM Multiplier & & 1.36 & 1.31 & & 1.34 & & 1.28 \\
\hline & \multirow{5}{*}{2017} & Direct & $\$$ & $67,524,391$ & 372 & $\$$ & $59,345,550$ & $\$$ & $8,020,218$ \\
\hline & & Indirect & $\$$ & $2,947,088$ & 44 & $\$$ & $1,834,815$ & $\$$ & $1,088,670$ \\
\hline & & Induced & $\$$ & $17,518,004$ & 138 & $\$$ & $10,335,971$ & $\$$ & $5,174,172$ \\
\hline & & Total & $\$$ & $87,970,629$ & 555 & $\$$ & $71,499,766$ & $\$$ & $14,280,821$ \\
\hline & & SAM Multiplier & & 1.30 & 1.49 & & 1.20 & & 1.78 \\
\hline
\end{tabular}




\begin{tabular}{|c|c|c|c|c|c|c|c|c|c|}
\hline \multicolumn{3}{|c|}{ Region 5 - Southern Region } & \multicolumn{2}{|r|}{ Output } & \multirow{2}{*}{$\frac{\text { Employment }}{672}$} & \multicolumn{2}{|c|}{ Value Added } & \multicolumn{2}{|c|}{$\begin{array}{c}\text { Employee } \\
\text { Compensation }\end{array}$} \\
\hline \multirow{10}{*}{$\begin{array}{c}\text { Primary } \\
\text { Solid Wood } \\
\text { Products }\end{array}$} & \multirow{5}{*}{2006} & Direct & $\$$ & $185,776,190$ & & $\$$ & $53,033,108$ & $\$$ & $35,942,512$ \\
\hline & & Indirect & $\$$ & $70,909,459$ & 500 & $\$$ & $33,334,416$ & $\$$ & $18,535,509$ \\
\hline & & Induced & $\$$ & $23,009,159$ & 159 & $\$$ & $12,990,245$ & $\$$ & $5,553,323$ \\
\hline & & Total & $\$$ & $268,081,403$ & 1,282 & $\$$ & $96,298,970$ & $\$$ & $57,836,913$ \\
\hline & & SAM Multiplier & & 1.44 & 1.91 & & 1.82 & & 1.61 \\
\hline & \multirow{5}{*}{2017} & Direct & $\$$ & $171,416,592$ & 556 & $\$$ & $29,265,144$ & $\$$ & $20,747,043$ \\
\hline & & Indirect & $\$$ & $93,116,480$ & 527 & $\$$ & $56,593,221$ & $\$$ & $21,911,756$ \\
\hline & & Induced & $\$$ & $35,333,853$ & 278 & $\$$ & $20,827,364$ & $\$$ & $10,451,919$ \\
\hline & & Total & $\$$ & $290,305,039$ & 1,325 & $\$$ & $105,162,922$ & $\$$ & $51,940,559$ \\
\hline & & SAM Multiplier & & 1.69 & 2.38 & & 3.59 & & 2.50 \\
\hline
\end{tabular}

\begin{tabular}{|c|c|c|c|c|c|c|c|c|c|}
\hline \multicolumn{3}{|c|}{ Region 5 - Southern Region } & \multicolumn{2}{|r|}{ Output } & \multirow{2}{*}{$\frac{\text { Employment }}{477}$} & \multicolumn{2}{|c|}{ Value Added } & \multicolumn{2}{|c|}{$\begin{array}{c}\text { Employee } \\
\text { Compensation } \\
\end{array}$} \\
\hline \multirow{10}{*}{$\begin{array}{c}\text { Secondary } \\
\text { Solid Wood } \\
\text { Products }\end{array}$} & \multirow{5}{*}{2006} & Direct & $\$$ & $81,037,841$ & & $\$$ & $26,102,867$ & $\$$ & $18,776,727$ \\
\hline & & Indirect & $\$$ & $21,723,054$ & 138 & $\$$ & $9,680,887$ & $\$$ & $5,833,781$ \\
\hline & & Induced & $\$$ & $10,354,177$ & 72 & $\$$ & $5,846,707$ & $\$$ & $2,499,591$ \\
\hline & & Total & $\$$ & $112,509,343$ & 684 & $\$$ & $41,438,519$ & $\$$ & $26,974,927$ \\
\hline & & SAM Multiplier & & 1.39 & 1.43 & & 1.59 & & 1.44 \\
\hline & \multirow{5}{*}{2017} & Direct & $\$$ & $35,182,430$ & 184 & $\$$ & $10,389,554$ & $\$$ & $7,974,554$ \\
\hline & & Indirect & $\$$ & $13,699,627$ & 79 & $\$$ & $7,072,647$ & $\$$ & $3,601,811$ \\
\hline & & Induced & $\$$ & $8,711,214$ & 69 & $\$$ & $5,133,620$ & $\$$ & $2,577,670$ \\
\hline & & Total & $\$$ & $57,500,780$ & 331 & $\$$ & $22,568,189$ & $\$$ & $14,133,478$ \\
\hline & & SAM Multiplier & & 1.63 & 1.80 & & 2.17 & & 1.77 \\
\hline
\end{tabular}

\begin{tabular}{|c|c|c|c|c|c|c|c|c|c|}
\hline \multicolumn{3}{|c|}{ Region 5 - Southern Region } & \multicolumn{2}{|c|}{ Output } & \multirow{2}{*}{$\begin{array}{r}\text { Employment } \\
346\end{array}$} & \multicolumn{2}{|c|}{ Value Added } & \multicolumn{2}{|c|}{$\begin{array}{c}\text { Employee } \\
\text { Compensation }\end{array}$} \\
\hline \multirow{10}{*}{$\begin{array}{l}\text { Wood } \\
\text { Furniture }\end{array}$} & \multirow{5}{*}{2006} & Direct & $\$$ & $42,494,229$ & & $\$$ & $17,657,919$ & $\$$ & $14,647,697$ \\
\hline & & Indirect & $\$$ & $7,351,674$ & 50 & $\$$ & $3,604,764$ & $\$$ & $1,990,297$ \\
\hline & & Induced & $\$$ & $6,861,979$ & 48 & $\$$ & $3,875,234$ & $\$$ & $1,656,801$ \\
\hline & & Total & $\$$ & $56,711,565$ & 443 & $\$$ & $25,139,801$ & $\$$ & $18,296,342$ \\
\hline & & SAM Multiplier & & 1.33 & 1.28 & & 1.42 & & 1.25 \\
\hline & \multirow{5}{*}{2017} & Direct & $\$$ & $36,870,680$ & 304 & $\$$ & $9,242,205$ & $\$$ & $12,166,352$ \\
\hline & & Indirect & $\$$ & $11,171,523$ & 72 & $\$$ & $5,948,952$ & $\$$ & $3,067,459$ \\
\hline & & Induced & $\$$ & $10,310,511$ & 81 & $\$$ & $6,074,761$ & $\$$ & $3,051,708$ \\
\hline & & Total & $\$$ & $58,345,632$ & 458 & $\$$ & $21,264,158$ & $\$$ & $18,283,205$ \\
\hline & & SAM Multiplier & & 1.58 & 1.50 & & 2.30 & & 1.50 \\
\hline
\end{tabular}




\begin{tabular}{|c|c|c|c|c|c|c|c|c|c|}
\hline \multicolumn{3}{|c|}{ Region 5 - Southern Region } & \multicolumn{2}{|c|}{ Output } & \multirow{2}{*}{$\begin{array}{c}\text { Employment } \\
-\end{array}$} & \multicolumn{2}{|c|}{ Value Added } & \multicolumn{2}{|c|}{$\begin{array}{c}\text { Employee } \\
\text { Compensation }\end{array}$} \\
\hline \multirow{10}{*}{$\begin{array}{l}\text { Pulp, Paper, } \\
\text { and } \\
\text { Paperboard }\end{array}$} & \multirow{5}{*}{2006} & Direct & $\$$ & - & & $\$$ & - & $\$$ & - \\
\hline & & Indirect & $\$$ & - & - & $\$$ & - & $\$$ & - \\
\hline & & Induced & $\$$ & - & - & $\$$ & - & $\$$ & - \\
\hline & & Total & $\$$ & - & - & $\$$ & - & $\$$ & - \\
\hline & & SAM Multiplier & & & & & & & \\
\hline & \multirow{5}{*}{2017} & Direct & $\$$ & $2,106,647$ & 3 & $\$$ & 258,069 & $\$$ & - \\
\hline & & Indirect & $\$$ & $1,029,389$ & 5 & $\$$ & 560,900 & $\$$ & 268,123 \\
\hline & & Induced & $\$$ & 402,140 & 3 & $\$$ & 237,202 & $\$$ & 118,823 \\
\hline & & Total & $\$$ & $3,537,599$ & 11 & $\$$ & $1,056,100$ & $\$$ & 386,946 \\
\hline & & SAM Multiplier & & 1.68 & 3.90 & & 4.09 & & \\
\hline
\end{tabular}

\begin{tabular}{|c|c|c|c|c|c|c|c|c|c|}
\hline \multicolumn{3}{|c|}{ Region 5 - Southern Region } & \multicolumn{2}{|c|}{ Output } & \multirow{2}{*}{$\frac{\text { Employment }}{3}$} & \multicolumn{2}{|c|}{ Value Added } & \multicolumn{2}{|c|}{$\begin{array}{c}\text { Employee } \\
\text { Compensation }\end{array}$} \\
\hline \multirow{10}{*}{$\begin{array}{c}\text { Secondary } \\
\text { Paperboard } \\
\text { and other } \\
\text { Paper } \\
\text { Products }\end{array}$} & \multirow{5}{*}{2006} & Direct & $\$$ & 929,561 & & $\$$ & 167,152 & $\$$ & 157,376 \\
\hline & & Indirect & $\$$ & 101,949 & 1 & $\$$ & 53,292 & $\$$ & 30,962 \\
\hline & & Induced & $\$$ & 69,553 & 0 & $\$$ & 39,285 & $\$$ & 16,797 \\
\hline & & Total & $\$$ & $1,101,172$ & 3 & $\$$ & 244,514 & $\$$ & 190,810 \\
\hline & & SAM Multiplier & & 1.18 & 1.13 & & 1.46 & & 1.21 \\
\hline & \multirow{5}{*}{2017} & Direct & $\$$ & $1,003,393$ & 2 & $\$$ & 144,727 & $\$$ & 115,425 \\
\hline & & Indirect & $\$$ & 257,624 & 2 & $\$$ & 144,389 & $\$$ & 80,125 \\
\hline & & Induced & $\$$ & 138,776 & 1 & $\$$ & 81,772 & $\$$ & 41,074 \\
\hline & & Total & $\$$ & $1,399,781$ & 5 & $\$$ & 370,887 & $\$$ & 236,622 \\
\hline & & SAM Multiplier & & 1.40 & 2.15 & & 2.56 & & 2.05 \\
\hline
\end{tabular}




\section{REFERENCES}

Aruna, P.B., F. Cubbage, K.J. Lee, \& C. Redmon. (1997). Regional economic contributions of the forest-based industries in the South. Forest Product Journal. 47(7/8), 35-45.

Berman, A., \& Plemmons, R. J. (1979). Input-Output Analysis in Economics. In Nonnegative Matrices in the Mathematical Sciences (pp. 243-270).

Brandeis, C., \& Hodges, D. G. (2015). Forest Sector and Primary Forest Products Industry Contributions to the Economies of the Southern States: 2011 Update. Journal of Forestry, 113(2), 205-209.

Castro, J. E. (2018, September 6). WV's storied forests a continuously renewable resource. Charleston Gazette-Mail. Retrieved from https://www.wvgazettemail.com/dailymailwv/daily_mail_features/wv-s-storied-forests-acontinuously-renewable-resource-daily-mail/article_49ba8cb6-731e-576f-baf81f1c23dd3c86.html

Cheney, P. (2018, September). Explaining the Type SAM Multiplier. Retrieved from https://implanhelp.zendesk.com/hc/en-us/articles/115009674768-Explaining-the-Type-SAMMultiplier

Cheney, P. (2018, May). IMPLAN Sectoring \& NAICS Correspondences. Retrieved from https://implanhelp.zendesk.com/hc/en-us/articles/115009674428-IMPLAN-Sectoring-NAICSCorrespondences

Childs, R. A. (2005, June). West Virginia's Forests: Growing West Virginia's Future. West Virginia University Bureau of Business and Economic Research. Retrieved from http://www.wvforestry.com/Economic\%20Impact\%20Study.pdf

Coronado, C. J., McConnell, T. E., \& Matthews, S. N. (2015). Forestry and Forest Products In Ohio: 2011 Economic Impacts with Comparison to 2011 Values. Wood and Fiber Science, 47(2), $1-11$.

Dahal, Ram \& Munn, Ian \& Henderson, James. (2013). Economic Impacts of the Forest Products Industry in the South (2009).

Dahal, Ram P., Henderson, J.E., \& Munn, I.A. (2015) Forest Products Industry Size and Economic Multipliers in the US South. Forest Products Journal: 2015, 65(7/8), 372-380.

Grushecky, S. T., \& Wang, J. (2013). The Impact of Natural Gas Development on Forest Operations in West Virginia. Retrieved from https://www.cofe.frec.vt.edu/documents/2013/Grushecky_Wang.pdf 
Henderson, J. E., Joshi, O., Tanger, S., Boby, L., \& Hubbard, W. (2017). Standard Procedures and Methods for Economic Impact and Contribution Analysis in the Forest Products Sector. Journal of Forestry, 115(2), 112-116.

Henderson, J. E., G. K. Evans. (2017). Single and multiple industry economic contribution analysis using IMPLAN. Forest and Wildlife Research Center, Research Bulletin FO468, Mississippi State University. 12 pp.

Herald-Dispatch staff, wire reports. (2017, July 19). WV Forestry dispatches members to fight wildfires. The Herald-Dispatch. Retrieved from https://www.herald-dispatch.com/news/wvforestry-dispatches-members-to-fight-wildfires/article_3b34f6f4-5ea8-5c55-86601f2e602eacb1.html

Hodges, D. G., Hartsell, A. J., Brandeis, C., Brandeis, T. J., \& Bentley, J. W. (2011). Recession Effects on the Forests and Forest Products Industries of the South. Forest Products Journal, 61(8), 614-624.

Hushak, L. (2005). Economics of Ohio's forest products industry. Unpublished report submitted to the School of Natural Resources, The Ohio State University, Columbus. 49p.

Joshi, O., Henderson, J. E., Tanger, S. M., Boby, L. A., Pelkki, M. H., \& Taylor, E. L. (2017). A Synopsis of Methodological Variations in Economic Contribution Analyses for Forestry and Forest-Related Industries in the US South. Journal of Forestry, 115(2), 80-85.

Khanal, P. N., Straka, T. J., \& Willis, D. B. (2017, April). Economic Contribution Analysis of South Carolina's Forestry Sector, 2017. Retrieved from https://www.state.sc.us/forest/economicimpactstudy2017.pdf

Leefers, L. A. (2017, December). Statewide Report: Forest Product Industries' Economic Contribution to Michigan's Economy - 2017 Update. Michigan Department of Natural Resources.

Luppold, W. G., \& Bumgardner, M. S. (2016). US Hardwood Lumber Consumption and International Trade from 1991 to 2014. Wood and Fiber Science, 48(3), 162-170.

Marks, R. (2017, January 30). Justice Releases Details of Timber Industry Plan. The State Journal. Retrieved from https://www.wvnews.com/statejournal/justice-releases-details-of-timberindustry-plan/article_28aed881-6afa-591a-a4fc-9b2e2371256b.html

Miller, R. E., \& Blair, P. D. (2009). Input-Output Analysis: Foundations and Extensions 2nd Edition. New York: Cambridge University Press.

Morin et al. 2018. Morin, Randall S. 2018. Forests of West Virginia, 2017. Resource Update FS174. Newtown Square, PA: U.S. Department of Agriculture, Forest Service, Northern Research Station. 3 p. https://doi.org/10.2737/FS-RU-174. 
Parajuli, R., Henderson, J. E., Tanger, S. M., Joshi, O., \& Dahal, R. (2018). Economic Contribution Analysis of the Forest-Product Industry: A Comparison of the Two Methods for Multisector Contribution Analysis Using IMPLAN. Journal of Forestry, XX(X), 1-7.

SGFS 2019. Southern Group of State Foresters, Southern Regional Extension Forestry. (2019, January). The Economics of Forestry. Retrieved from http://forestryimpacts.net/reports

Snedegar, J. (2018, January 17). W.Va. Timber: Furniture Company Thriving in Berkeley Springs. WV Public Broadcasting. Retrieved from https://www.wvpublic.org/post/wva-timberfurniture-company-thriving-berkeley-springs\#stream/0

Stringer, J., Thomas, B., \& Ammerman, B. (2018). Kentucky Forest Sector Economic Contribution Report 2016-2017. Retrieved from https://forestry.ca.uky.edu/files/2018_ky_contribution_reportfinal_highest_quality.pdf

Tillley, B., \& Munn, I. A. (2007). 2001 Economic Impacts of the Forest Products Industry in the South. Southern Journal of Applied Forestry, 31(4), 181-186.

Watson, P., Wilson, J., Thilmany, D., \& Winter, S. (2007). Determining Economic Contributions and Impacts: What is the difference and why do we care? Journal of Regional Analysis and Policy, 37(2), 1-15.

Woodall, C. W., Piva, R. J., Skog, K. E., Ince, P. J., \& Luppold, W. G. (2011). An Assessment of the Downturn in the Forest Products Sector in the Northern Region of the United States. Forest Products Journal, 61(8), 604-613. 